Portland State University

PDXScholar

Summer 9-11-2019

\title{
Seismic Source Characterization of Faults in the Portland and Tualatin Basins and a Paleoseismic Study of the Gales Creek Fault, OR
}

Alison Elizabeth Horst

Portland State University

Follow this and additional works at: https://pdxscholar.library.pdx.edu/open_access_etds

Part of the Geology Commons

Let us know how access to this document benefits you.

\section{Recommended Citation}

Horst, Alison Elizabeth, "Seismic Source Characterization of Faults in the Portland and Tualatin Basins and a Paleoseismic Study of the Gales Creek Fault, OR" (2019). Dissertations and Theses. Paper 5267. https://doi.org/10.15760/etd.7140

This Thesis is brought to you for free and open access. It has been accepted for inclusion in Dissertations and Theses by an authorized administrator of PDXScholar. Please contact us if we can make this document more accessible: pdxscholar@pdx.edu. 
Seismic Source Characterization of Faults in the Portland and Tualatin Basins and a Paleoseismic Study of the Gales Creek Fault, OR

by

Alison Elizabeth Horst

A thesis submitted in partial fulfillment of the requirements for the degree of

Master of Science

in Geology

Thesis Committee:

Ashley Streig, Chair

John Bershaw

Ray E. Wells

Portland State University

2019 


\begin{abstract}
Portland, OR lies within the tectonically active forearc of the Cascadia subduction zone. Several, potentially hazardous, northwest striking faults in and around the Portland Basin are classified as Quaternary active by the USGS, but little is known about their Holocene activity. Geologic and geodetic studies in the Pacific Northwest (PNW) document ongoing clockwise rotation of the region since at least $16 \mathrm{Ma}$. Models for crustal deformation in the PNW suggest northwest trending faults accommodate dextral shear inferred from increasing clockwise rotation rates west of Portland. I compiled structural information to improve the seismic source characterization of these faults, and using empirical scaling relationships for fault length and earthquake magnitude, I find that many of the faults in the region are capable of generating earthquakes of magnitude 6 to 7 .
\end{abstract}

The focus of this study is the Gales Creek fault (GCF) which is the longest northwest-trending fault in the study area with prominent geomorphic expression, located $35 \mathrm{~km}$ west of Portland. In addition to a seismogenic source characterization, I investigated the GCF through paleoseismic trenching to document the style and timing of surface deforming earthquakes. I interpret three surface rupturing earthquakes from stratigraphic and structural relationships in the trench. Radiocarbon samples from offset stratigraphy constrain these earthquakes to have occurred $\sim 1,000, \sim 4,200$ and $\sim 8,800$ calibrated years before present. The penultimate earthquake backtilted a buried soil into the hillslope creating accommodation space that was infilled by a colluvial deposit. The most recent earthquake faulted and formed a fissure within the penultimate colluvial deposit. My results suggest the GCF is active, and has experienced at least three surface- 
deforming earthquakes in the Holocene. New earthquake timing constraints presented here, combined with ongoing research on the central GCF will better constrain the lateral extent of prehistoric surface rupturing earthquakes, and can be used to refine magnitude estimates for the GCF. 


\section{ACKNOWLEDGEMENTS}

This research was supported by funding from the National Science Foundation (Award \# 1349577) the Department of Energy (DOE), and a Geological Society of America Graduate Student Research Grant (2018).

I would like to thank my advisor, Ashley Streig, for the opportunity to attend Portland State for graduate school, and for her guidance, patience, and support throughout the past two years. I would also like to thank my committee members, John Bershaw and Ray Wells for their expertise and constructive feedback, and the group involved with the DOE project: Erick Burns, Ben Perkins, and Ellen Svadlenak, for their advice and feedback.

I owe a special thanks to the Forest Grove Engineering office for allowing us access to the watershed all summer and to undertake an excavation on their property, in particular Rob Foster, Andy Sewall, and Marcey Crowell.

Huge thanks to my three hard-working, insightful, and pleasant field assistants, Alexis Judy, Lana Jewel, and Albert Gitnes, for coming out to help dig and log the trench on many early mornings; this project would not have been possible without you! Thanks to other students that helped out in the field: Lena Fox, Samantha Gillette, Dale Melton, Garrett Manshold, Ryan Levinson, Markie Martindale, and Dr. Streig’s Earthquake Geology class.

Thank you to Tom Guilderson and Danielle Verdugo for teaching and helping me with the pre-treatment process for radiocarbon dating at Lawrence Livermore National Laboratory. 
Thank you to the folks at Stimson Lumber for providing us access to their land to do field reconnaissance. Thank you to the Bureau of Reclamation and the reviewers who came out the trench in October, 2018, for providing great discussions and feedback about the project.

I would like to also thank Scott Burns, Andrew Fountain, and all of the graduate students in the geology department at Portland State for supporting me, providing feedback, and helping with various aspects of this project. 


\section{TABLE OF CONTENTS}

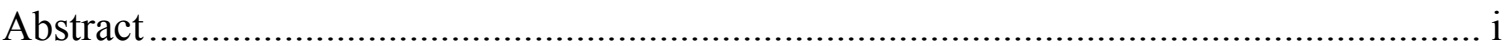

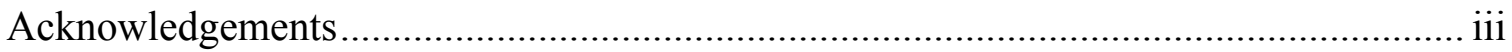

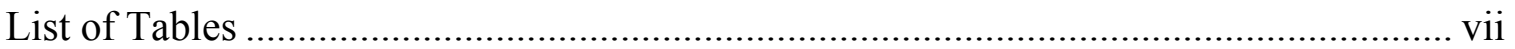

List of Figures .................................................................................................. vii

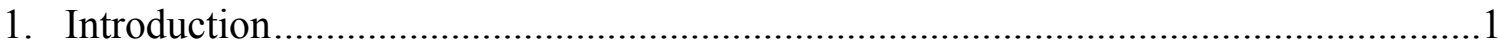

2. Geologic Setting...........................................................................................

2.1. Pacific Northwest Tectonics ...................................................................

2.2. Northwest Oregon Regional Seismic Sources ..............................................5

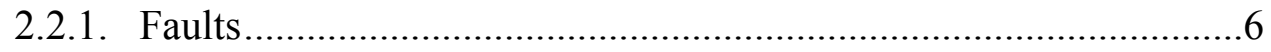

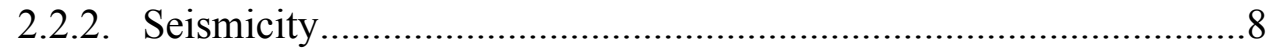

2.3. Gales Creek Fault................................................................................ 11

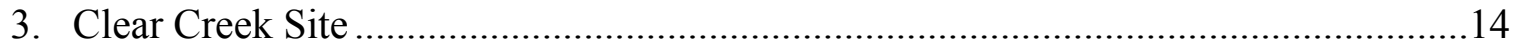

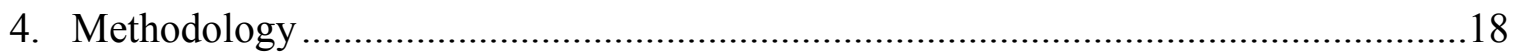

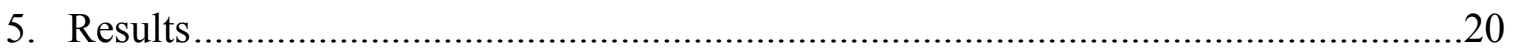

5.1. Clear Creek Trench Stratigraphy ...........................................................20

5.1.1. Units Northeast of Fault Zone.................................................20

5.1.2. Units Southwest of Fault Zone ...............................................24

5.2. Clear Creek Trench Structure .................................................................26

5.3. Deposit Age Estimates and Sedimentation Rates ......................................26

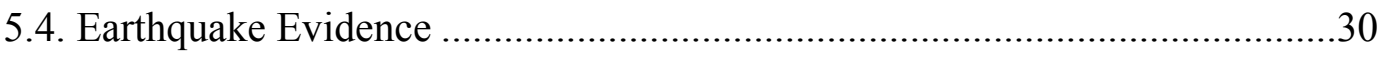

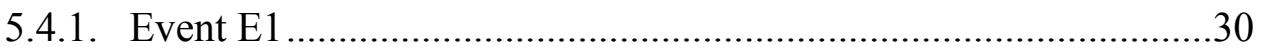

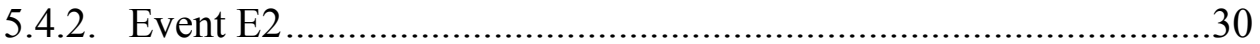


5.4.3. Event E3

5.4.4. Weak Evidence of Younger Surface Deformation .32

5.4.5. Possible Earlier Deformation .32

6. Discussion. .33

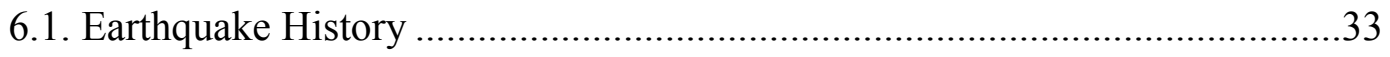

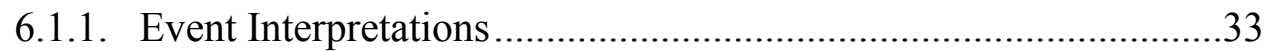

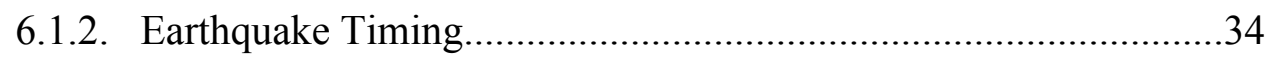

6.1.3. Evidence of Younger Deformation (E0) ....................................38

6.1.4. Evidence of Older Deformation (EE) .......................................38

6.2. Paleoearthquake Magnitude, Rupture Length, and Displacement Estimates .39

6.2.1. Right-Laterally Deflected Drainages .....................................41

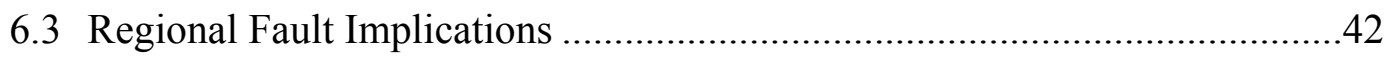

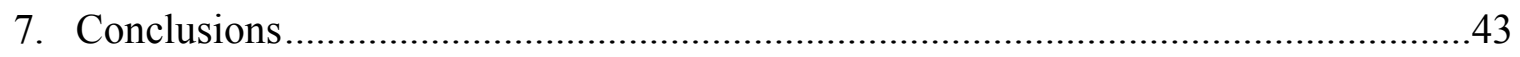

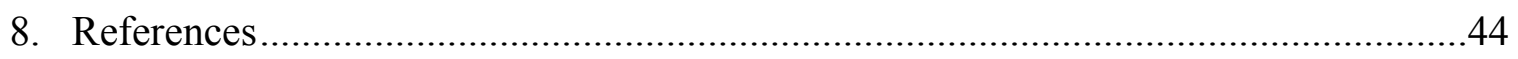

Appendix A. Portland Metropolitan Fault Database ................................................52

Appendix B. Fault data from focal mechanisms ...................................................67

Appendix C. Clear Creek trench detailed stratigraphic unit descriptions.......................68

Appendix D. Photomosaic and interpreted trench log for northwest and southeast walls

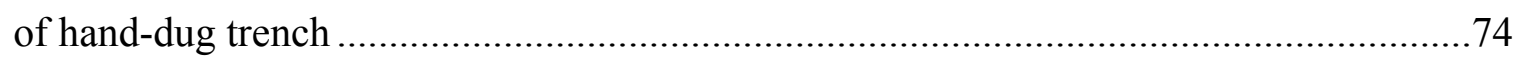

Appendix E. Photomosaic and interpreted trench log for north and south walls of V-

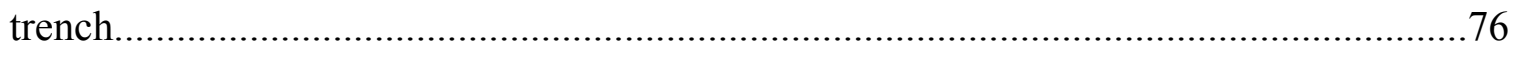

Appendix F. Summary of Earthquake Evidence ............................................... 78 
Appendix G. OxCal model with earthquakes for samples not included in Figure 8 and table of ${ }^{14} \mathrm{C}$ data with $2 \sigma$ uncertainty

Appendix H. Alternate OxCal Model with E2 between units 50 and 60, and Table of 14C

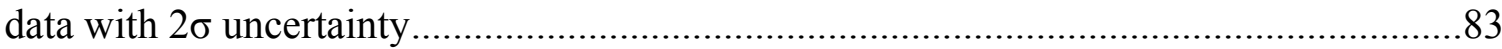

Appendix I. Links for Publically Accessible Data Sources used in this study .................85 


\section{LIST OF TABLES}

Table 1. Fault metrics for seismic source characterization ..........................................

Table 2. Maximum earthquake magnitude and average displacement calculations for

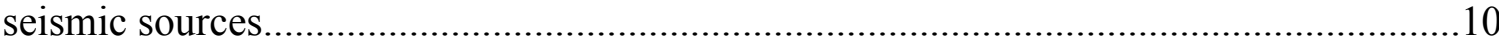

Table 3. Measurements of deflected drainages along the northern Gales Creek fault......13

Table 4. Radiocarbon Results for detrital charcoal samples from the Clear Creek trench

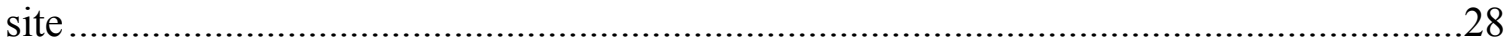




\section{LIST OF FIGURES}

Figure 1. Regional map of Quaternary active faults and microseismicity in the Portland and Tualatin Basins

Figure 2. (a) Topography along the Gales Creek fault trace (b) Northern section of GCF with deflected drainages

Figure 3. (a) Geologic map of northern GCF (b) Slope map with contours showing the GCF

Figure 4. (a) Photograph of the Clear Creek trench site before excavation (b) Lidarderived elevation profile taken perpendicular to GCF fault trace.

Figure 5. Lidar-derived elevation profile taken perpendicular to GCF, highlighting two side-hill benches $100 \mathrm{~m} \mathrm{SW}$ of Clear Creek site

Figure 6. Stratigraphic column and descriptions of deposits on a photomosaic base separated on either side of the GCF fault zone .20

Figure 7. Photomosaics, linework, and interpreted trench logs for the northwest and southeast walls of the Clear Creek trench site .22

Figure 8. Summary of age results from stratigraphic ordering using OxCal version 4.3, showing probability density functions for radiocarbon samples with $2 \sigma$ uncertainty .......27 Figure 9. Scatter plot of calibrated radiocarbon ages versus stratigraphic depth below the

ground surface.

Figure 10. Photomosaic of meters $\mathrm{H} 2$ - H4 exposed in the hand-dug trench, northwest wall

Figure 11. Schematic reconstruction of vertical deformation from earthquakes E1 and E2 created by incrementally retro-deforming the northwest trench log 


\section{Introduction}

Off the coast of the Pacific Northwest (PNW), the Cascadia subduction zone extends from Northern California to Vancouver Island, British Columbia. Here, the Juan de Fuca plate subducts beneath North America along the Cascadia megathrust. In the forearc, the Puget-Willamette lowland is home to several of the largest cities in the PNW including: Vancouver, B.C. (V), Seattle (Se), Olympia (O), Portland (P), Salem (Sa), and Eugene (E) (Figure 1) (Blakely et al., 2000). Seismic hazards in subduction zones include megathrust earthquakes and associated tsunamis, deep intraplate earthquakes, as well as distributed inland crustal deformation. Oblique convergence from the Cascadia subduction zone has led to arc-parallel migration of the forearc (McCaffrey, 1994; Wells et al., 1998) and evidence from GPS, geologic deformation, and paleomagnetic data reveal clockwise rotation of the crust, relative to stable North America (Wells et al., 1998). With deformation distributed across a network of crustal faults, slip rates are low and it is likely many of these faults have not been active in the historical time period.

Geophysical and geologic observations indicate the Portland Basin has experienced folding and faulting since the middle Miocene (Beeson et al., 1985; Blakely et al., 1995). Several northwest-striking faults in and around the Portland Basin (Figure 1) are classified as Quaternary active in the Quaternary Fault and Fold Database (QFFD) (U.S. Geological Survey, 2006), though little is known about their recent activity. The PNW is mountainous and densely forested, which makes identification of fault scarps in the field problematic. Surface expression on these faults has recently been revealed by high-resolution topographic maps, derived from Light Detection and Ranging (lidar). If rotation observed with GPS is accommodated as north-south compression and translation 


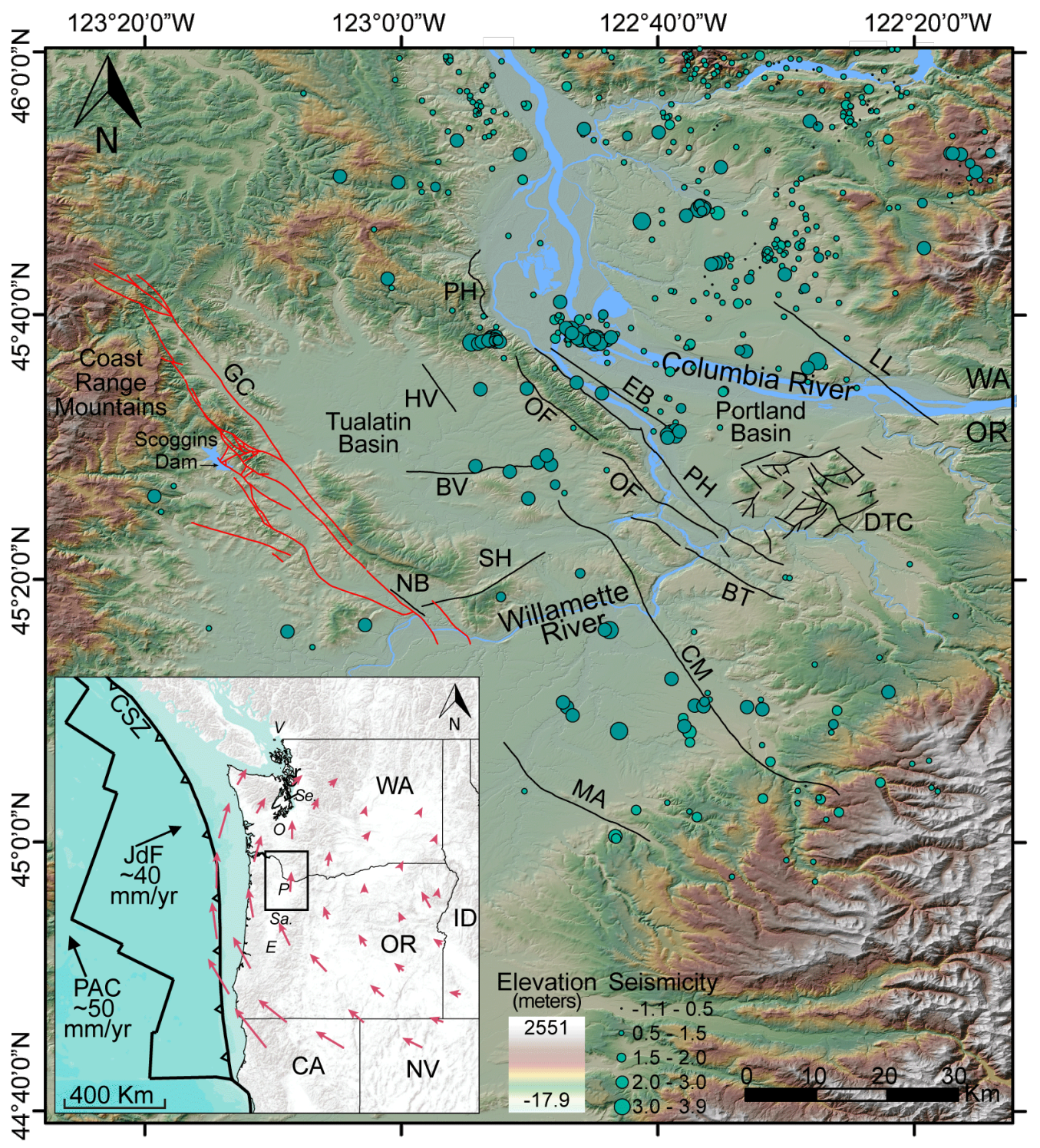

Figure 1. Regional map of Quaternary active faults and microseismicity in the Portland and Tualatin Basins on a lidar-derived hillshade overlain on a transparent elevation map. Locations for all faults except Gales Creek and Sherwood are from Quaternary Fold and Fault Database; Gales Creek and Sherwood faults mapped by Wells and others (2018). Faults labeled: GC: Gales Creek (shown in red), BV: Beaverton, SH: Sherwood, MA: Mount Angel, CM: Canby-Molalla, BT: Bolton, OF: Oatfield, EB, East Bank, PH: Portland Hills, LL: Lackamas Lake, and DTC: Damascus-Tickle Creek (DTC shown on map but not included in seismic source characterization due to lack of data on the fault). (Inset) Tectonic setting of Pacific Northwest United States showing GPS surface velocity vectors (pink arrows) relative to a stable North America (McCaffrey et al., 2013, 2016). Cascadia Subduction zone labeled CSZ; rates of motion on the Juan de Fuca (JdF) and Pacific (PAC) plates are indicated by black arrows, modified from Carlson and others (2017). Black box shows area of Figure 1. 
along northwest trending fault zones in the Puget-Willamette lowland (Wells and McCaffrey, 2013), then northwest trending faults in the Portland and Tualatin Basins are likely active and accommodating dextral slip.

The primary objective of this research is to evaluate faults in the Portland and Tualatin Basins and investigate whether they are active and accommodating regional stresses. In order to understand how crustal block rotation and northward translation is affecting faults around Portland, I present a catalog of fault characteristics from faults in the Portland and Tualatin Basins compiled using existing literature on fault parameters such as strike, dip, length, and sense of movement. The Gales Creek fault (GCF) is the longest northwest-trending fault in the study area with prominent geomorphic expression, located $35 \mathrm{~km}$ west of Portland. In addition to a seismogenic source characterization, I investigated the GCF through paleoseismic trenching to document the style and timing of surface deforming earthquakes. My results indicate the GCF is Holocene active and has experienced at least three surface-deforming earthquakes in the Holocene.

Over two million people live in the greater Portland metropolitan area, a region with mapped bedrock faults, and no paleoseismic studies to document prehistoric earthquakes. In 1993, the Scotts Mills earthquake occurred just south of Portland and caused approximately 30 million dollars in damage (Liberty et al., 2003). A similar rupture today closer to the populated city center would be devastating. Considering that the Gales Creek fault is Holocene active (results herein) due to regional north-south compressive stress, it is likely other, similarly oriented bedrock faults in the region are also active. 


\section{Geologic Setting}

\subsection{Pacific Northwest Tectonics}

Strain accumulating in the forearc of the Cascadia subduction zone occurs from northeast-directed subduction as well as the northward migration of the Oregon forearc block (McCaffrey et al., 2013; Morell et al., 2017). Geologic studies along the Oregon Coast Range and Cascade Volcanic Arc have noted clockwise rotation from paleomagnetic north for at least the past 16 million years (Wells and McCaffrey, 2013; Wells and Simpson, 2001). Western Oregon has rotated $1.19+/-0.1$ degrees/m.y. about a vertical axis through most of the Cenozoic (Wells and McCaffrey, 2013). Block models have been developed to explain on-going rotation and translation of the Oregon coast and forearc (Wells et al., 1998; Wells and Simpson, 2001; Wells and McCaffrey, 2013). Deformation from rotation is expressed as extension in the Basin and Range, shortening in the northern Cascade Arc and across the Yakima fold and thrust belt. In the Oregon Coast Range and Puget-Willamette lowland, these models show that rotation is associated with translation along crustal faults. Observations of active high-angle crustal faults oriented in the northwest direction within the forearc of Cascadia suggest regional transpression (Morell et al., 2017). If the block models are correct, northwest trending faults accommodate Quaternary dextral displacement. Block models suggest the northern Oregon and Washington forearc are accommodating approximately $7-9 \mathrm{~mm} / \mathrm{yr}$. of shortening (Wells et al.,1998). Wells and others (1998) estimate the Oregon forearc block accounts for 4-7 mm/yr. of this slip. Accordingly, faults at the latitude of the Portland Metropolitan area (Table 1 and Appendix A) have an estimated distributed slip of 
approximately $5 \mathrm{~mm} / \mathrm{yr}$., extending into the backarc (Wells et al., 1998; Wong et al., 2001).

The Portland region has had few historical earthquakes to inform seismic hazard characterization. There are about a dozen mapped faults in the Quaternary Fault and Fold Database (QFFD) (U.S. Geological Survey, 2006), and sparse paleoseismic data for the region. The Scotts Mills earthquake was one of the most notable historic earthquakes in the region. This $\mathrm{Mw}=5.7$ earthquake occurred on March 25, 1993, on a restraining bend of the Mount Angel fault just south of Portland (Blakely et al., 1995; Thomas et al., 1996). Focal mechanisms from this earthquake revealed reverse and right-lateral motion (Thomas et al., 1996). This is consistent with north-south compressive stress along the northwest trending Gales Creek-Mount Angel fault zone (Blakely et al., 2000). A similar rupture closer to the urban corridor would pose significant risk to infrastructure in the Portland metropolitan area (Wong et al., 2000; Tesfamariam and Wang, 2011).

\subsection{Northwest Oregon Regional Seismic Sources}

The seismic source characterization is a compilation of fault length, strike, dip, sense of movement, slip rate, most recent activity, displacement, and other fault parameters compiled from published literature and a review of earthquake focal mechanisms. The historic earthquake record is a very small portion of the entire fault record, and faults have likely not produced the greatest magnitude earthquake they are capable of in this time period (Burbank and Anderson, 2011).

There are twelve faults in the Portland and Tualatin Basins in the QFFD (U.S. Geological Survey, 2006), and numerous bedrock faults are mapped in the region (Wells et al., 2018). A fault is considered to be sufficiently active if it has ruptured in the 
Holocene, since approximately 11 ka (Bryant, 2010). All of the faults in the Portland and Tualatin Basins included in the QFFD are classified as late Quaternary $(<130,000$ years) or older, besides the Mount Angel fault (latest Quaternary: $<15,000$ years) (U.S. Geological Survey, 2006) (Table 1). The Portland Basin has a long geologic history of deposition and erosion (Liberty et al., 2003) in a region that receives large amounts of precipitation. Therefore, any surface expression on these faults is likely indicative of geologically youthful features.

Wells and Coppersmith (1994) compiled a global catalog of surface rupturing earthquakes and earthquake parameters including fault type, rupture length, and magnitude earthquake produced, and developed an empirical scaling relationship for fault rupture length and earthquake magnitude. Using this relationship, I estimate the maximum magnitude earthquake that could be generated on the faults in the Portland area. I use Hanks and Bakun (2002) to estimate maximum earthquake magnitude based on fault rupture area, with maximum depth to the base of seismogenic crust in the PNW estimated between 20 and $25 \mathrm{~km}$ (Hyndman et al., 2003). I also used the relationship between displacement and rupture length from Wells and Coppersmith (1994) and calculated average displacement that could occur on each of these fault lengths. Primary characteristics of these seismic sources are shown in Table 1, and a more comprehensive database can be found in Appendix A. Information on maximum magnitude earthquake and average displacement can be found in Table 2.

\subsubsection{Faults}

The steeply dipping Portland Hills-Clackamas River fault zone and Sandy RiverFrontal fault zones (also referred to as the Lackamas Lake fault), bounding the Portland 
Basin, are interpreted to be right-stepping, right-lateral zones of a pull-apart basin (Yelin and Patton, 1991, Evarts et al., 2009; McPhee et al., 2014). McPhee and others (2014) interpret gravity data to suggest fold and thrust geometry resulting from Neogene compression has been superimposed on ancestral pull-apart basins. Major northwesttrending structures in the greater Portland Metropolitan region include the Portland HillsClackamas River, Gales Creek-Mount Angel, and Canby-Molalla fault systems (Figure $1)$.

The Portland Hills fault zone (PHFZ) includes the Portland Hills, East Bank, and Oatfield faults (Wong et al., 2001) (Figure 1). Previous studies report variable dips ranging from $70^{\circ}-90^{\circ}$, and all structures in the PHFZ have dip-slip displacements (Blakely et al., 1995; Beeson et al., 1989; Yelin, 1992; Wong et al., 2000). Focal mechanisms for earthquakes between July-October 1991 along the PHFZ had right-lateral and reverse sense of strain (Blakely et al., 1995). The Portland Hills fault is widely interpreted to be steeply dipping to the northeast (Beeson et al., 1989; Pratt et al., 2001; Schlicker et al., 1964; Balsille and Benson, 1971). However, recent gravity data inverted for the region reveals a sub-vertical Portland Hills fault and steeply southwest dipping East Bank fault (McPhee et al., 2014). McPhee and others (2014) show normal, southwest-side-down, displacement of Columbia River Gorge Basalt (CRB) and Paleogene and Early Miocene sedimentary units across the East Bank fault. Aeromagnetic data show the Oatfield fault to have a significant reverse component, with 15 Ma CRB structurally above 1 Ma Boring Lava (Walsh et al., 2011; Fleck et al., 2014). 


\subsubsection{Seismicity}

Focal mechanisms from historical seismicity demonstrate the Portland Basin has had elements of shortening, extension, and dextral slip on faults (Evarts et al., 2009). As previously mentioned, the Mw 5.7 Scotts Mills earthquake had reverse and right-lateral focal mechanisms. Conversely, on November 6, 1962, a Mw 5.2 earthquake occurred in the Portland Basin on a right-lateral fault and had a component of normal slip near Vancouver, WA (Yelin and Patton, 1991). A series of reverse-right lateral earthquakes M $\leq 2.8$ occurred along the northern end of the Portland Hills in 1982-1985 (Blakely et al., 1995; Yelin and Patton, 1991). During July-October 1991 there was another swarm of reverse-right lateral earthquakes at the north end of the Portland Hills with magnitudes $\leq$ 3.5. The largest of the 1991 earthquakes showed reverse and dextral-slip mechanisms (Yelin and Patton, 1991; Yelin, 1992). Diverse earthquake focal mechanisms observed on faults indicate the Portland Basin has had a complicated history of deformation. 
Table 1. Fault metrics for seismic source characterization. Ages from US Geological Survey (2006); references for other characteristics can be found in Appendix A.

\begin{tabular}{|c|c|c|c|c|c|}
\hline Fault & $\begin{array}{c}\text { Dip } \\
\text { Direction }\end{array}$ & $\begin{array}{c}\text { Dip } \\
\text { Angle }\end{array}$ & $\begin{array}{c}\text { Sense of } \\
\text { Movement }\end{array}$ & $\begin{array}{c}\text { Length } \\
(\mathrm{km})\end{array}$ & Age (QFFD) \\
\hline Beaverton & South & $70^{\circ}$ & Reverse & 15 & $\begin{array}{l}\text { Middle and late } \\
\text { Quaternary }\end{array}$ \\
\hline Bolton & West & $70^{\circ}$ & $\begin{array}{l}\text { Reverse \& right- } \\
\text { lateral strike slip }\end{array}$ & 9 & $\begin{array}{l}\text { Class B (Various } \\
\text { age) }\end{array}$ \\
\hline $\begin{array}{l}\text { Canby- } \\
\text { Molalla }\end{array}$ & Northeast & $70^{\circ}$ & Right-lateral & 51 & Late Quaternary \\
\hline East Bank & Northeast & $70^{\circ}-90^{\circ}$ & $\begin{array}{l}\text { Reverse \& right- } \\
\text { lateral strike slip }\end{array}$ & 55 & $\begin{array}{l}\text { Middle and late } \\
\text { Quaternary }\end{array}$ \\
\hline Gales Creek & West & $70^{\circ}-90^{\circ}$ & $\begin{array}{l}\text { Reverse \& right- } \\
\text { lateral strike slip }\end{array}$ & 73 & $\begin{array}{l}\text { Undifferentiated } \\
\text { Quaternary }\end{array}$ \\
\hline Helvetia & West & $70^{\circ}$ & $\begin{array}{l}\text { Reverse \& right- } \\
\text { lateral strike slip }\end{array}$ & 10 & $\begin{array}{l}\text { Undifferentiated } \\
\text { Quaternary }\end{array}$ \\
\hline $\begin{array}{l}\text { Lackamas } \\
\text { Lake }\end{array}$ & Southwest & $70^{\circ}$ & $\begin{array}{l}\text { Normal \& right- } \\
\text { lateral strike slip }\end{array}$ & 44 & $\begin{array}{l}\text { Middle and late } \\
\text { Quaternary }\end{array}$ \\
\hline Mount Angel & Northeast & $60^{\circ}-70^{\circ}$ & $\begin{array}{l}\text { Reverse \& right- } \\
\text { lateral strike slip }\end{array}$ & 32 & Latest Quaternary \\
\hline Newberg & Southwest & $70^{\circ}$ & Reverse & 8 & $\begin{array}{l}\text { Undifferentiated } \\
\text { Quaternary }\end{array}$ \\
\hline Oatfield & Northeast & $70^{\circ}$ & $\begin{array}{l}\text { Reverse \& right- } \\
\text { lateral strike slip }\end{array}$ & 40 & $\begin{array}{l}\text { Undifferentiated } \\
\text { Quaternary }\end{array}$ \\
\hline $\begin{array}{l}\text { Portland } \\
\text { Hills }\end{array}$ & Southwest & $70^{\circ}$ & $\begin{array}{l}\text { Reverse \& right- } \\
\text { lateral strike slip }\end{array}$ & 62 & $\begin{array}{l}\text { Undifferentiated } \\
\text { Quaternary }\end{array}$ \\
\hline Sherwood & South & $50^{\circ}$ & Reverse & 14.5 & $\begin{array}{l}\text { N/A (from bedrock } \\
\text { faults) }\end{array}$ \\
\hline
\end{tabular}




\begin{tabular}{|c|c|c|c|c|c|c|c|c|c|c|c|c|c|c|c|c|}
\hline \multirow{12}{*}{ 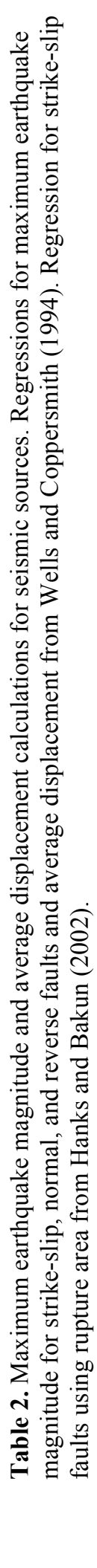 } & \multirow{5}{*}{ 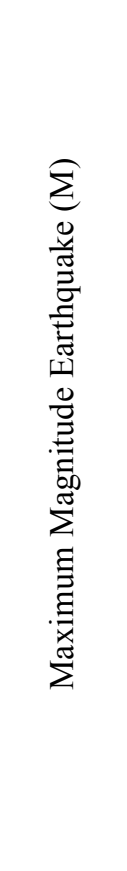 } & 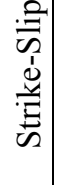 & 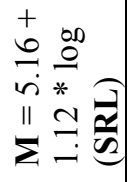 & & $\tilde{n}$ & $\stackrel{\sim}{\sim}$ & $\stackrel{\circ}{\circ}$ & ชె & $\stackrel{\infty}{b}$ & $\stackrel{\circ}{r}$ & nె. & $\stackrel{\Upsilon}{\sim}$ & $\vec{\pi}$ & $\vec{\pi}$ & ชె & $\ddot{q}$ \\
\hline & & $\begin{array}{l}0 \\
0 \\
\overline{0} \\
\overrightarrow{0} \\
\simeq\end{array}$ & 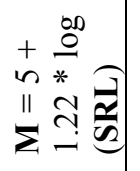 & & $\vec{b}$ & $\stackrel{\Upsilon}{ת}$ & $\stackrel{\circ}{r}$ & $\overrightarrow{0}$ & $\stackrel{\infty}{\sigma}$ & & ชֶ. & $\stackrel{m}{r}$ & $\vec{r}$ & $\vec{r}$ & ชె & $\stackrel{\nabla}{\circ}$ \\
\hline & & 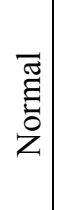 & 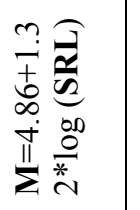 & & & & & & & $\stackrel{\circ}{\circ}$ & & & & & & \\
\hline & & 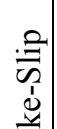 & $\begin{array}{c}*_{0}^{0} \\
\hat{m} \\
\dot{m} \\
+\end{array}$ & $\stackrel{\Xi}{\Sigma}$ & $\vec{b}$ & $\stackrel{\Upsilon}{\pi}$ & ఫे & $\stackrel{0}{0}$ & $\stackrel{\infty}{0}$ & $\stackrel{\circ}{\circ}$ & $\overrightarrow{0}$ & $\stackrel{?}{r}$ & $\overparen{r}$ & 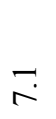 & $\overrightarrow{6}$ & ఫें \\
\hline & & $\vec{n}$ & 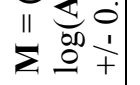 & $\stackrel{\check{\Xi}}{\Sigma}$ & $\tilde{0}$ & $\stackrel{?}{r}$ & $\ddot{\pi}$ & $\overrightarrow{0}$ & $\hat{\sigma}$ & $\ddot{r}$ & ?ִ & $\stackrel{⿱ 亠}{\sim}$ & $\stackrel{?}{r}$ & $\stackrel{\Upsilon}{r}$ & ชู & $\tilde{b}$ \\
\hline & 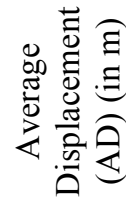 & 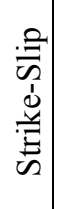 & 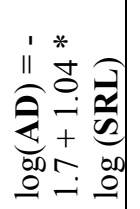 & & $\dddot{m}$ & $\because$ & $\dot{0}$ & ก̋ & $\tilde{o}$ & $\stackrel{\circ}{-}$ & ก̋ & I & $\stackrel{?}{n}$ & $\stackrel{\text { I }}{\sim}$ & $\tilde{o}$ & ?ִ \\
\hline & & & $\stackrel{\Xi}{\Sigma}$ & 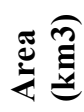 & 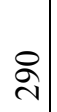 & $\underset{\stackrel{9}{+}}{\mathrm{I}}$ & $\underset{\infty}{\infty}$ & $\stackrel{8}{-}$ & @o & $\begin{array}{l}\infty \\
\infty \\
\infty\end{array}$ & $\underset{\sim}{~}$ & $\begin{array}{l}8 \\
\stackrel{0}{+}\end{array}$ & $\stackrel{8}{=}$ & તิ & $\stackrel{\infty}{-}$ & \& \\
\hline & & & $\stackrel{\pi}{\Sigma}^{x}$ & 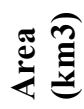 & $\begin{array}{l}n \\
\text { io } \\
n\end{array}$ & $\begin{array}{l}0 \\
n \\
n\end{array}$ & $\stackrel{8}{8}$ & $\underset{\sim}{\stackrel{\sim}{2}}$ & $\underset{\infty}{\infty}$ & $\stackrel{8}{\Xi}$ & $\stackrel{n}{n}$ & $\begin{array}{l}2 \\
\infty \\
\infty\end{array}$ & $\stackrel{n}{n}$ & 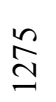 & $\stackrel{\sim}{\sim}$ & $\stackrel{n}{n}$ \\
\hline & & & $\stackrel{\Xi}{\Sigma}$ & 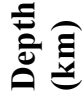 & $\stackrel{\sim}{ }$ & 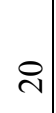 & $\stackrel{\sim}{ }$ & 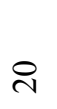 & ㄱ. & $\stackrel{\sim}{ }$ & ㄱ. & 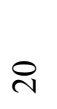 & $\stackrel{\sim}{\text { v }}$ & 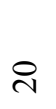 & 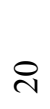 & $\stackrel{\sim}{ }$ \\
\hline & & & 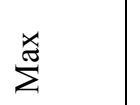 & 营 & $\approx$ & $\approx$ & $\approx$ & $\approx$ & $\approx$ & $\ddot{\sim}$ & $\approx$ & $\ddot{\sim}$ & $\approx$ & $\ddot{\sim}$ & $\ddot{\sim}$ & $\ddot{n}$ \\
\hline & & & $\overline{\underline{\alpha}}$ & 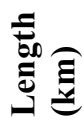 & $\stackrel{?}{ \pm}$ & $\widehat{\sigma}$ & \& & $\infty$ & กे & $\stackrel{\nabla}{\forall}$ & $\stackrel{ }{-}$ & $\stackrel{\Re}{\sim}$ & $n$ & $\vec{n}$ & $a$ & 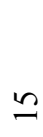 \\
\hline & & & & 产 & $\begin{array}{l}\overrightarrow{8} \\
0 \\
0 \\
\frac{3}{2} \\
\frac{1}{n}\end{array}$ & 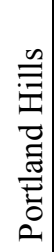 & 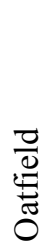 & $\begin{array}{l}\text { bo } \\
\text { Dे } \\
\sum_{0}^{0} \\
z\end{array}$ & 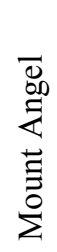 & 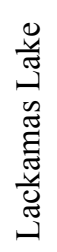 & 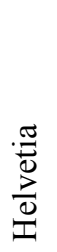 & 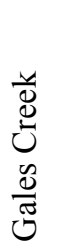 & 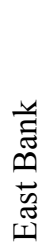 & $\begin{array}{l}\frac{\pi}{\pi} \\
\frac{\pi}{0} \\
\sum_{1}^{0} \\
0 \\
0 \\
\tilde{\Xi}\end{array}$ & $\begin{array}{l}\stackrel{0}{0} \\
\stackrel{0}{\circ} \\
\text { ص }\end{array}$ & 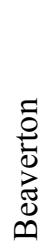 \\
\hline
\end{tabular}




\subsection{Gales Creek Fault}

The northwest trending Gales Creek fault forms the boundary between the Coast Range uplift and the Northern Willamette Valley (Figures 1 and 2a) (Blakely et al., 2000). The fault has significant surface expression, and a strong gravity gradient on the order of $110 \mathrm{mGal}$ exists along at least $50 \mathrm{~km}$ of the fault (Wells et al., 2009). Magnetic data show 10-15 km of dextral offset in Eocene basement (Blakely et al., 2000; Wells et al., 2009; McPhee et al., 2014). Subhorizontal slickensides and drag folding are consistent with dextral slip on the fault (Wells et al., 2009; 2018). To the south and on trend with the GCF, the Mount Angel fault generated a 5.7 Mw earthquake in 1993. It is possible that the GCF connects with the similarly northwest trending Mount Angel fault in the subsurface (Blakely et al., 2000) (Figure 1).

If a fault has generated a large surface-rupturing earthquake in the late Holocene, surface expression should be apparent in local topography. Lidar and aerial imagery along the 73-km long GCF trace reveal strong surface expression in rugged, steep, forested mountainous terrain. Previous mapping identified uphill-facing scarps, offset streams, and shutter ridges along the western end of the GCF (Wells et al., 2009). Along the northern most part of the GCF, I analyzed the mapped fault trace and main stream channels using ESRI basemaps in ArcGIS and Google Earth. I mapped four dextrally deflected drainages in the study area of Clear Creek site (Figure 2b). Offsets were measured by projecting trends of both the upstream and downstream sections to the fault traces. Lateral displacement measured for all deflected drainages that crossed the GCF range from $\sim 700$ to 2,000 meters (Figure 2b, Table 3). The upstream channel of Iler Creek doesn't continue far past the fault trace; however, I include this drainage because 
elevation profiles across the creek indicate a steep channel of up to 100 feet deep that continues to the northwest.

In 2016, the Bureau of Reclamation excavated two paleoseismic trenches on the GCF at Scoggins Dam (Figure 1). Reclamation trenches revealed faulted charcoalbearing flood plain deposits, ${ }^{14} \mathrm{C}$ ages reveal the most recent event was Holocene in age (Redwine et al., 2017). Here, I present results from a new trench on the GCF near Clear Creek, north of the Scoggins Dam sites (Figure 1). Results from this study can be used to correlate evidence of surface rupturing earthquakes and earthquake timing along fault strike between sites, to geologically constrain minimum fault rupture lengths. The Holocene history of large paleoearthquakes on the GCF constrains GCF recurrence (earthquake frequency), its proportion of the regional slip rate budget, and past earthquake magnitudes for regional seismic hazard assessments. 
(a) $123^{\circ} 27^{\prime} 0^{\prime \prime} \mathrm{W}$

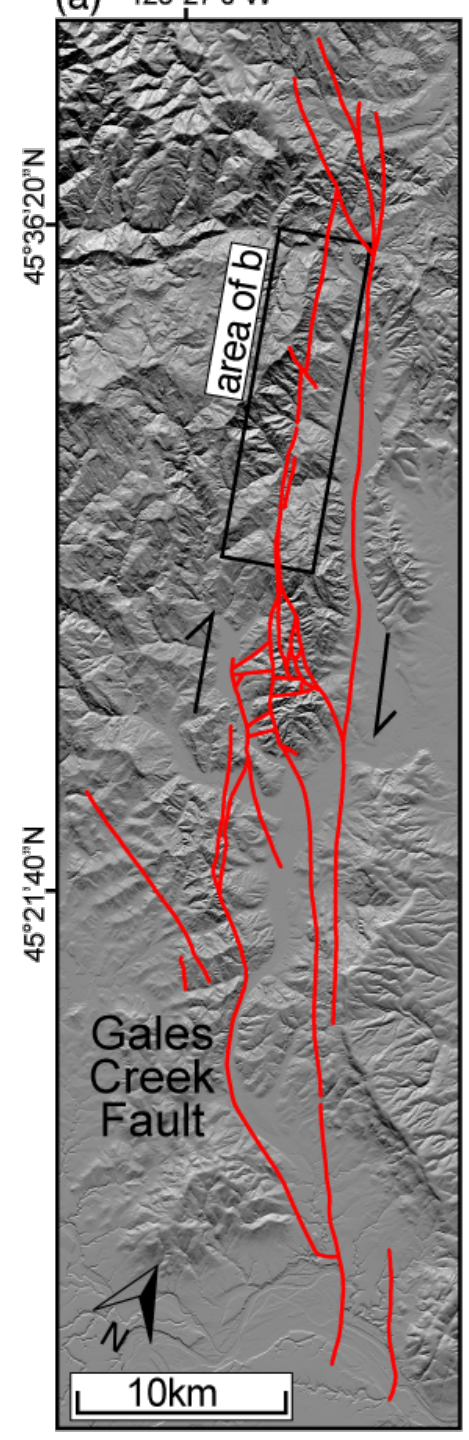

(b) $123^{\circ} 19^{\prime} 0^{\prime \prime} \mathrm{W}$

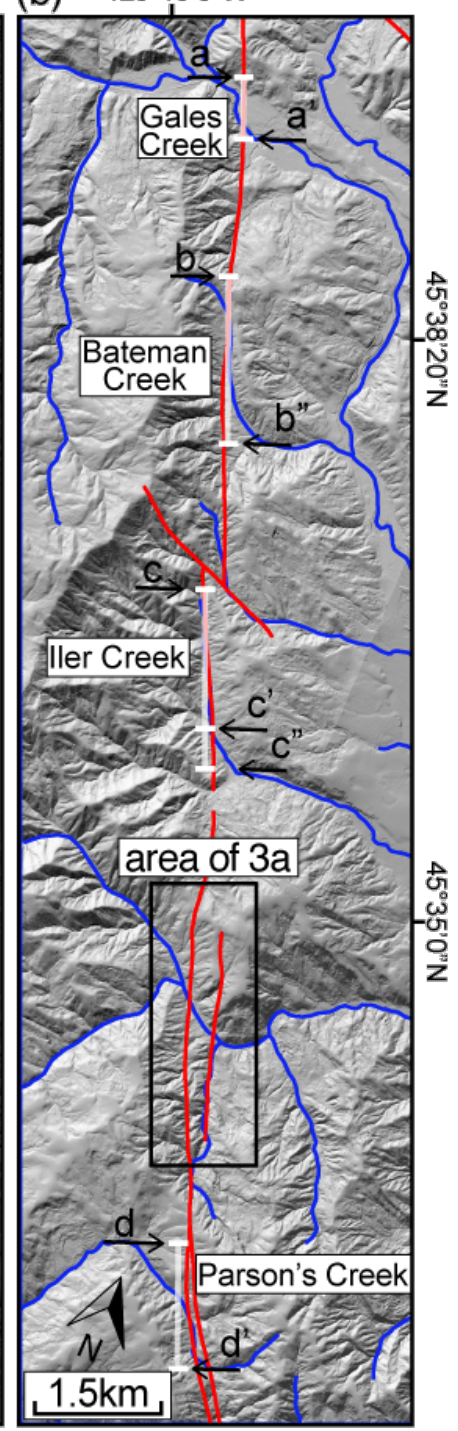

Figure 2. (a) Topography along the Gales Creek fault, fault trace from Wells and others (2018) on a hillshade produced from a filtered DEM derived from lidar data. Arrows show relative sense of movement on the fault. (b) Northern section of the GCF with deflected drainages shown in blue and the GCF red. White solid lines show measured offset along drainage. Black box shows area of Figure 3a.

Table 3. Measurements of deflected drainages along the northern Gales Creek fault.

\begin{tabular}{|l|l|l|}
\hline \multicolumn{1}{|c|}{ Stream Name } & $\begin{array}{c}\text { Channel } \\
\text { Offset }\end{array}$ & \multicolumn{1}{c|}{$\begin{array}{c}\text { Offset } \\
\text { Measurement }\end{array}$} \\
\hline Gales Creek & $\mathrm{a}-\mathrm{a}{ }^{\prime}$ & $753 \mathrm{~m}$ \\
\hline Bateman Creek & $\mathrm{b}-\mathrm{b} '$ & $1,966 \mathrm{~m}$ \\
\hline Iler Creek & $\mathrm{c}-\mathrm{c}^{\prime}$ & $1,615 \mathrm{~m}$ \\
\hline & $\mathrm{c}-\mathrm{c}^{\prime}$ & $2,064 \mathrm{~m}$ \\
\hline Parson's Creek & $\mathrm{d}-\mathrm{d} '$ & $1,459 \mathrm{~m}$ \\
\hline
\end{tabular}




\section{Clear Creek Site}

The Gales Creek fault is geomorphically expressed as well-defined linear breaks in slope along northeast-facing hillslopes in the area of the Clear Creek site. The Clear Creek site is located at the north end of the GCF (Figure 3). Local fault traces were previously mapped at a scale of 1:24,000 (Wells et al., 2018). I mapped small-scale ( 1 $\mathrm{m}$ relief) tectonic and geomorphic features in the Clear Creek study area with lidar derivatives generated from 3-foot bare earth DEMs. Lidar was collected by the Oregon Lidar Consortium.

The Clear Creek trench site on the GCF is about 200 meters east of Clear Creek (Figure 3); it is flanked by a northeast-facing hillslope mapped as Eocene intrusive rocks of the Coast Range (Figure 3a) (Wells et al., in press). At the Clear Creek site, the GCF is mapped at the inflection point of the hillslope on the southwest edge of the side-hill bench, and on the northeast margin of the flat side-hill bench, where the slope of the ground surface rapidly increases to $30^{\circ}$ (Figure 4). A sag pond is mapped $\sim 30$ m north of the site along the side-hill bench (Figure 3b). South of the site, I observe two side-hill benches, see elevation profile b-b' (Figure 5). A hand auger transect across the fault prior to trenching revealed abundant organic material for ${ }^{14} \mathrm{C}$ dating and correlative stratigraphy vertically offset across a fault (Figure 4). The trench was positioned along a $\sim 10$-meter-wide, flat-lying, side-hill bench (Figure 3b).

Landslides are mapped in the region around Clear Creek trench as Holocene and Pliocene Landslide deposits (Wells et al., 2018) (Figure 3a). I find no evidence of such a disturbance upslope of the Clear Creek trench, and no evidence of hummocky topography for these types of deposits downslope or adjacent to the trench site (Figure 3b). 

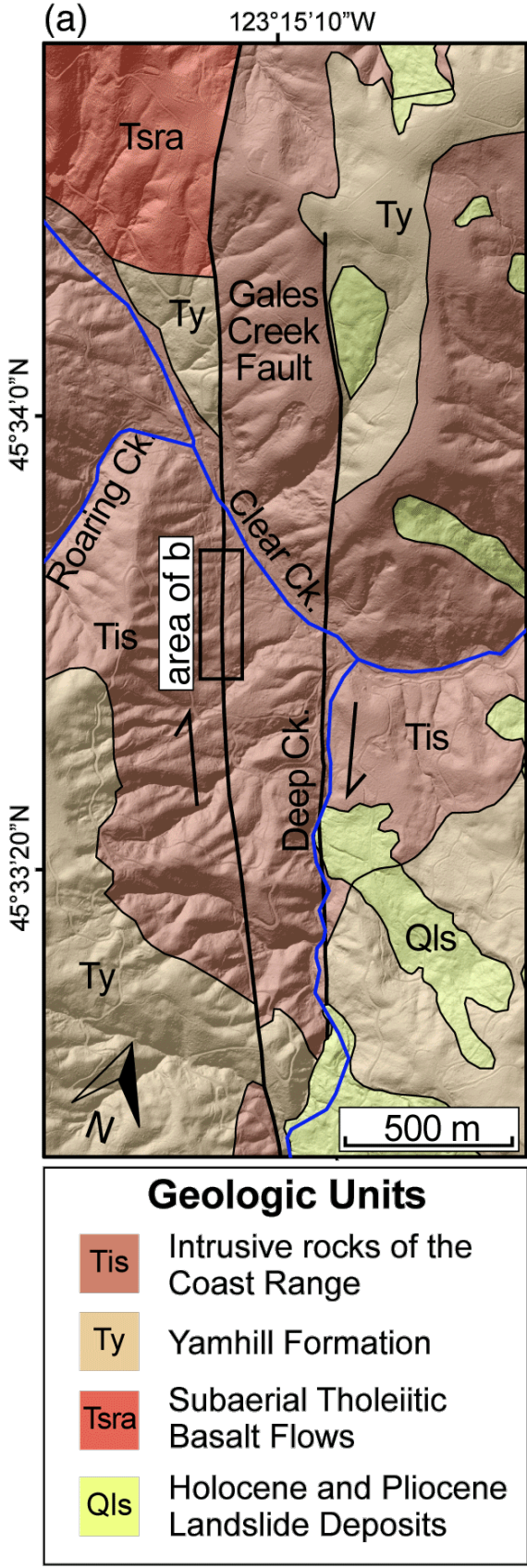

(b)
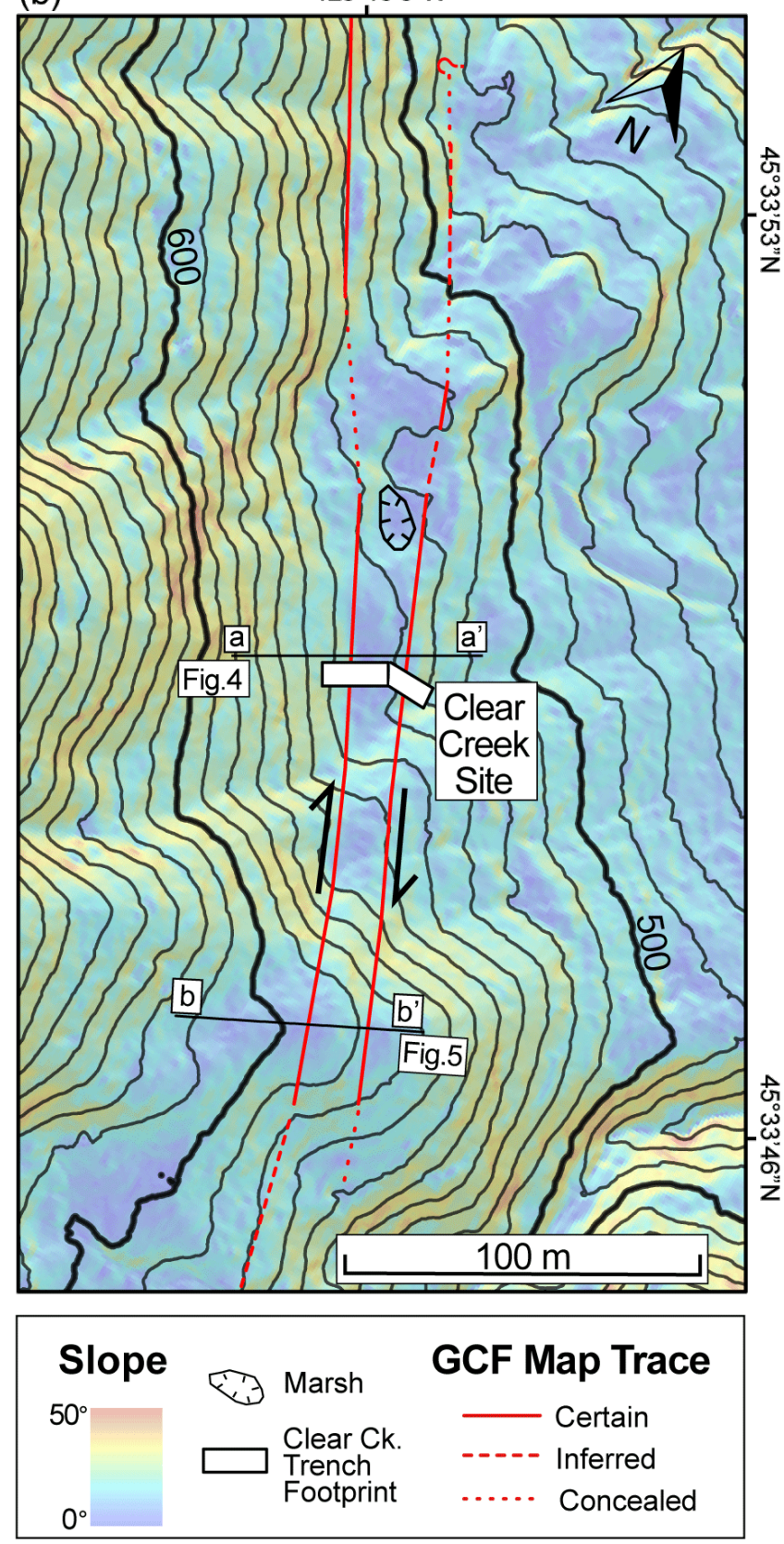

Figure 3. (a) Geological map of northern Gales Creek fault, Washington County, OR. (b) Slope map with contours showing the Gales Creek fault (red), a marsh along the fault, and locations of Figures 4 and 5 elevation profiles. Arrows show relative sense of motion (dextral) along the GCF. 


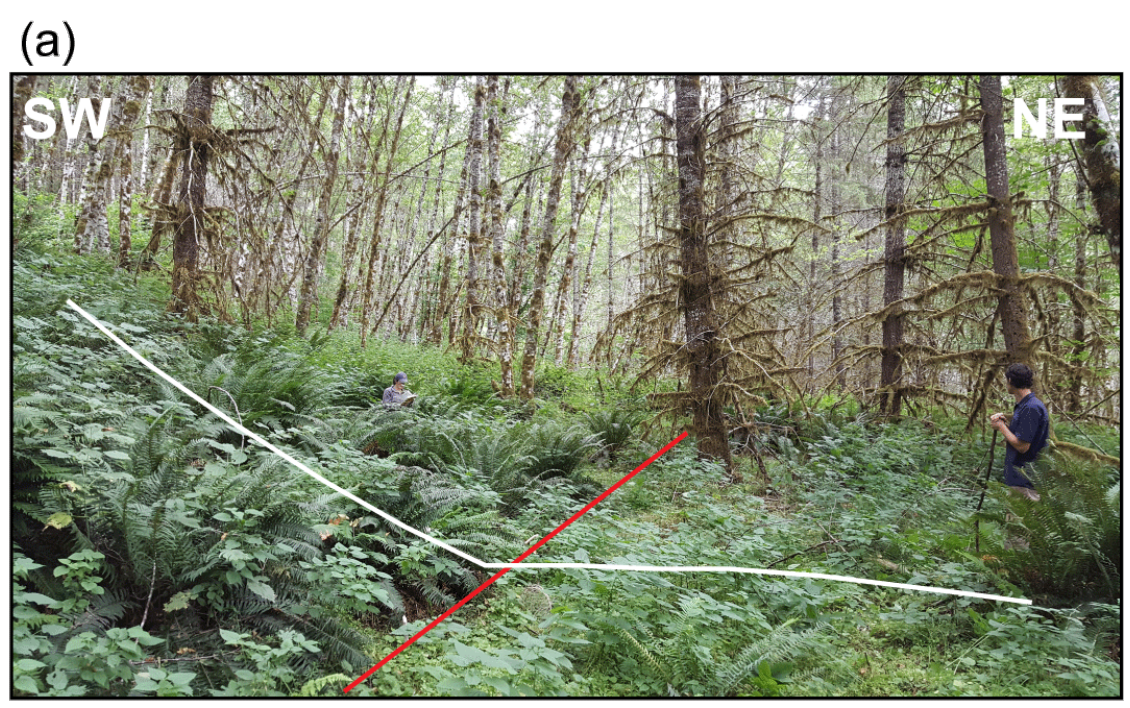

(b)

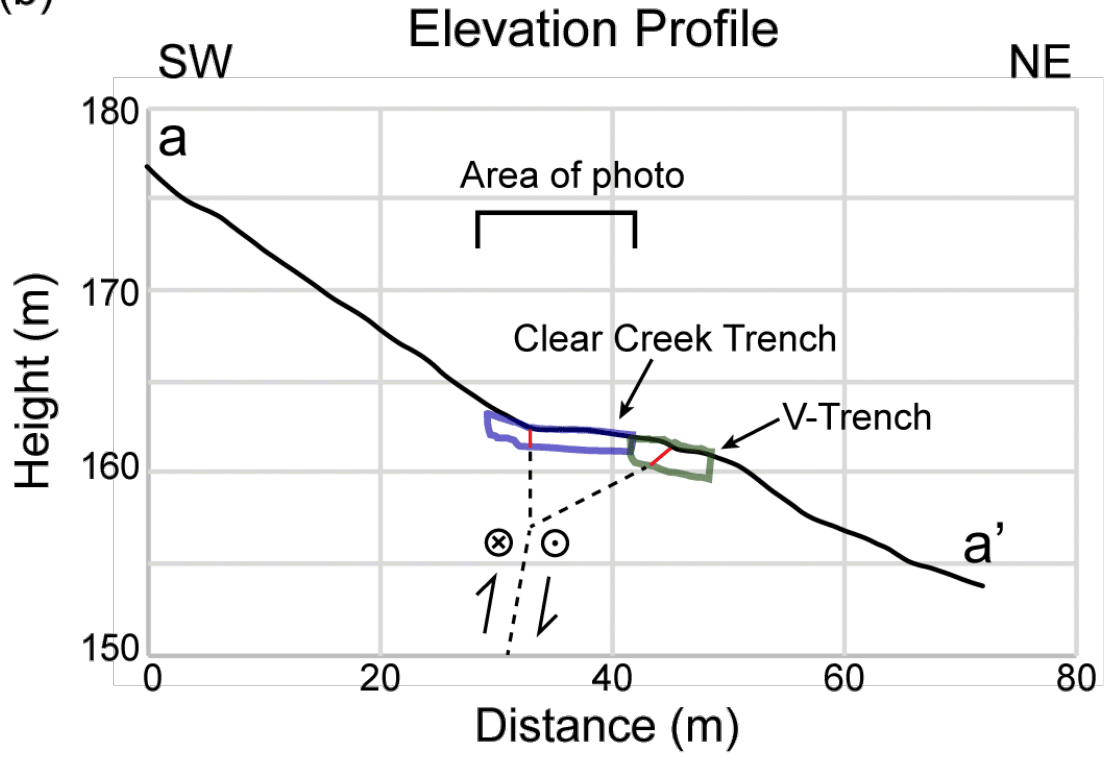

Figure 4. (a) Photograph of the Clear Creek trench site before excavation, photo looking northwest along the Gales Creek fault. The break in slope along the hillside, indicated by a red line, is where the Gales Creek fault forms a sidehill bench in the topography. Person for scale on the northeast side of the photo. (b) Lidar-derived elevation profile taken in ArcGIS perpendicular to the Gales Creek fault trace, showing the trench outline in blue and v-trench outline in green (not to scale because of oblique angle to profile). Fault traces observed in trenches shown in red, and GCF inferred as dotted black line at depth. 


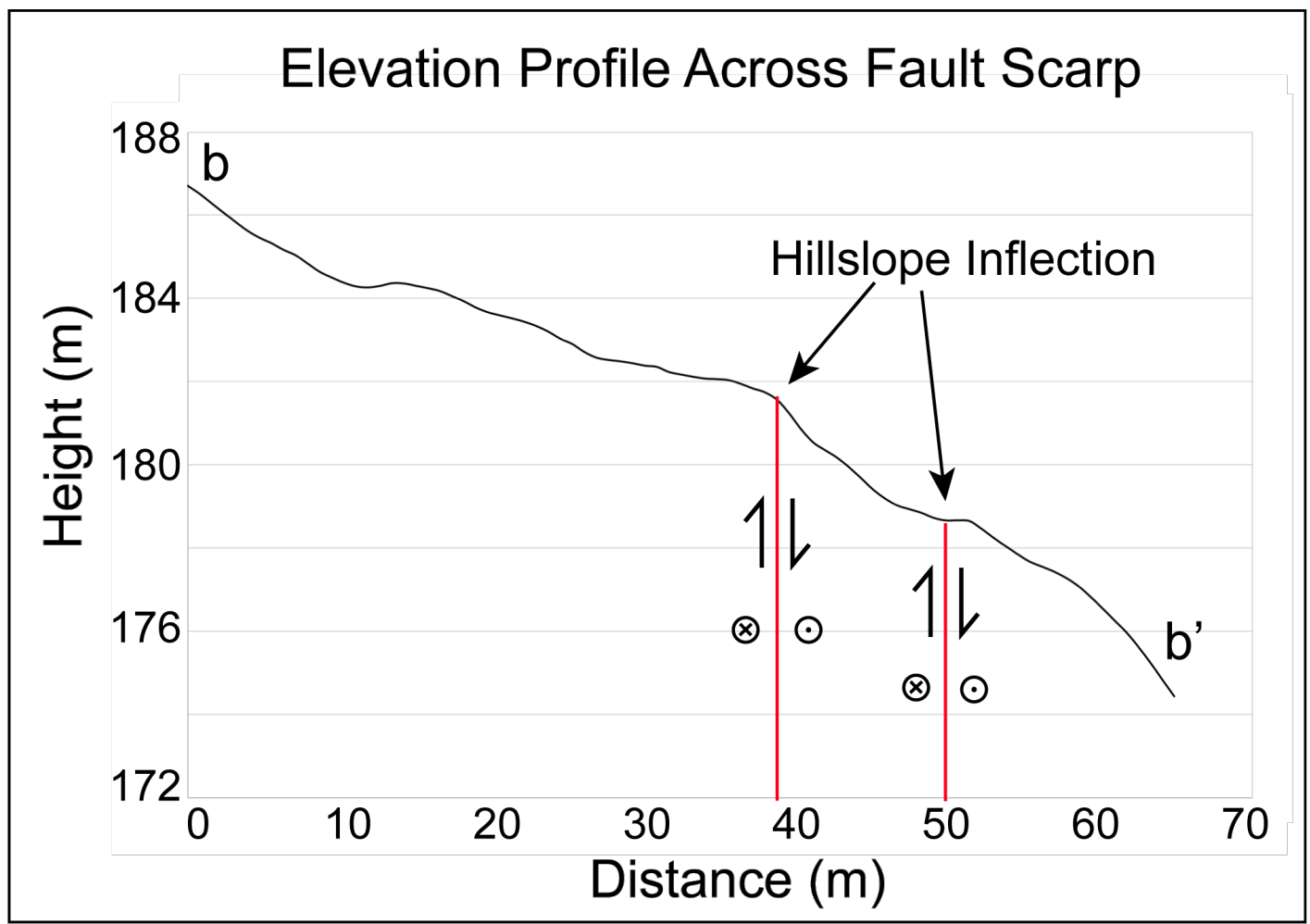

Figure 5. Lidar-derived elevation profile taken perpendicular to the Gales Creek fault trace, highlighting two side-hill benches along a high ridge located approximately $100 \mathrm{~m}$ southwest of the Clear Creek site. See Figure $3 \mathrm{~b}$ for location of elevation profile. 


\section{Methodology}

We excavated a fault-perpendicular trench across the GCF near Clear Creek road, Gales Creek, Washington County, OR. The primary trench was approximately 12 meters long and $1 \frac{1 / 2}{2}$ meters deep and oriented $\mathrm{N} 69^{\circ} \mathrm{E}$. The trench was dug by hand and then deepened post fire season with a backhoe. Downslope, the backhoe also excavated a 7meter long v-trench extension oriented $\mathrm{N}^{\circ} 6^{\circ} \mathrm{E}$, on the southeast end of the trench (Figure 3b). I collected differential GPS locations for the trench outline with a Trimble GeoXH and post processed points with GPS Pathfinder Software. We scraped trench walls to remove shovel marks and backhoe smear, and expose micro-stratigraphy. The trench exposure was gridded with a $1 \mathrm{~m}$ x $0.5 \mathrm{~m}$ nail grid as reference points for photomosaicing trench logs and taking measurements. High resolution orthomosaics were generated using Agisoft Photoscan software (Reitman et al., 2015). Stratigraphic units and structural relationships were documented and described on the photo logs, charcoal and OSL sample locations and bulk soil samples were also documented on these logs.

Sedimentological units were distinguished primarily based on soil type, color, moisture condition, and clast/grain size component percentages. I used detrital charcoal samples of key stratigraphic units to constrain the ages of the deposits using ${ }^{14} \mathrm{C}$ dating. I collected at total of 300 detrital charcoal samples from all units, and selected 27 samples from 9 stratigraphic units for Accelerated Mass Spectrometry (AMS) ${ }^{14} \mathrm{C}$ dating. I densely sampled stratigraphic units that closely bracket paleoearthquake horizons, and also selected samples from sequence stratigraphy between the key stratigraphic units for AMS dating (Table 4). Prior to lab submission, I cleaned the samples with DI water and removed excess material and modern rootlets. After samples were cleaned I sent them to 
Lawrence Livermore National Lab Center for AMS (LLNL CAMS) for ${ }^{14} \mathrm{C}$ dating, ${ }^{13} \mathrm{C}$ splits were also measured. I used OxCal v4.3.2 (Bronk-Ramsey, 2009) to construct a calibrated age model for stratigraphic units and earthquakes identified at the Clear Creek site. 


\section{Results}

\subsection{Clear Creek Trench Stratigraphy}

The Clear Creek trench exposed a buried organic soil horizon, slope-derived colluvium, and fissure deposits. I identify five primary stratigraphic units northeast of the fault zone, and four additional units southwest of the fault zone (Figures 6 and 7).

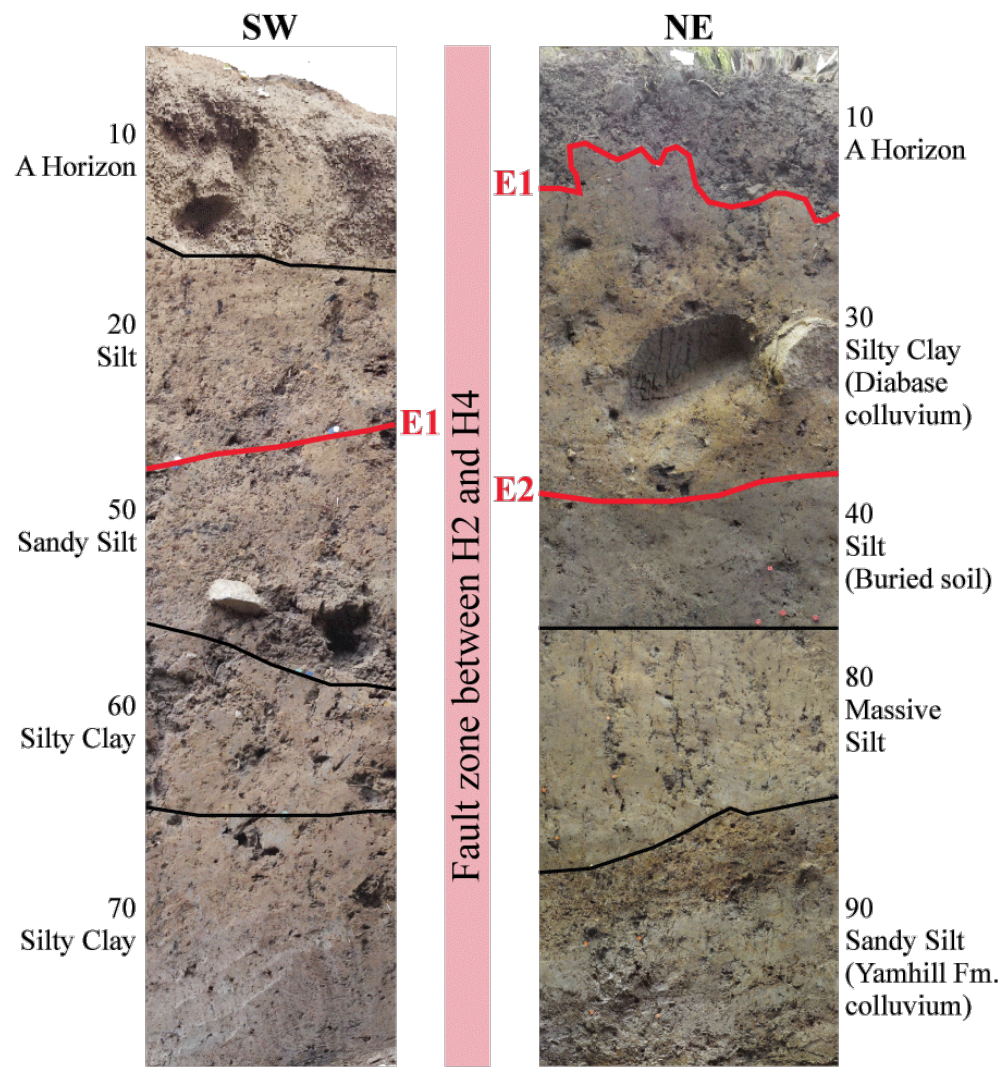

Figure 6. Stratigraphic columns and descriptions of deposits on a photomosaic base separated on either side of the GCF fault zone. The photomosaic is overlain with linework, black lines are unit contacts, and red lines are interpreted earthquake horizons (E1 and E2). Unit numbers are arbitrarily designated and displayed above soil type to the side of photomosaic.

\subsubsection{Units Northeast of Fault Zone}

The deepest and oldest stratigraphic unit, 90, is a massive, brown sandy silt, with 15-25 cm thick siltstone clastic interbeds. The clastic interbeds comprise approximately 
$<10 \%$ percent of the unit, the remaining $>90 \%$ of the unit is massive sandy silt with pockets of gray clay. Unit 90 is located $\sim 0.25 \mathrm{~m}$ to $2 \mathrm{~m}$ below the ground surface between meters $\mathrm{H} 7$ and $\mathrm{H} 12$ (in which $\mathrm{H}$ and $\mathrm{V}$ are trench wall grid coordinates and correspond with the trench logs, Figure 7). Unit 90 siltstone clastic interbeds consist of 1$7 \mathrm{~cm}$ sub-rounded to sub-prismoidal clasts that are oxidized brown, reddish yellow, dusky red, and white and contain redoximorphic mottles. The thin clastic interbeds dip $20-30^{\circ}$ to the southwest. Unit 90 is an interbedded colluvium sourced by angular shale clasts of the Eocene Yamhill Formation (Wells et al., in press).

Unit 80 is a massive yellowish-brown silt, with $1 \%$ small, $1 \mathrm{~cm}$ to $3 \mathrm{~cm}$ subrounded tan, pink, and light orange weathered siltstone pebbles. Unit 80 has weak, blocky pedogenic structure, orange mottles and common charcoal fragments. Unit 80 is laterally continuous between meters $\mathrm{H} 5$ and $\mathrm{H} 11$, and dips $\sim 20^{\circ}$ to the southwest (Figure 7). Unit 80 unconformably overlies unit 90 ; the base of unit 80 is eroded and diffuse over a few centimeters.

Unit 40 is a dark grayish-brown silt, with $1 \%$ small, $1 \mathrm{~cm}$ to $3 \mathrm{~cm}$ sub-rounded tan, pink, and light orange weathered siltstone pebbles and abundant charcoal. The upper horizon of unit 40 dips $\sim 10^{\circ}$ to the southwest. (Figure 7). Unit 40 has a wavy basal contact that is gradational over $3 \mathrm{~cm}$. Unit 40 ranges from a few centimeters thick at the northeast (Figure 7, H7) increasing in thickness to $0.5 \mathrm{~m}$ at the southwest (Figure 7, H3 H5). We did not excavate to the base of this unit at the southwest (Figure 7, H3 - H5) where it is thickest. On the southeast wall meters $\mathrm{H} 2-\mathrm{H} 5$ the stratigraphy darkened in color with depth from brown to dark grayish-brown, below this a second weaker medium grayish brown planar surface was observed. I interpret these changes in sediment 


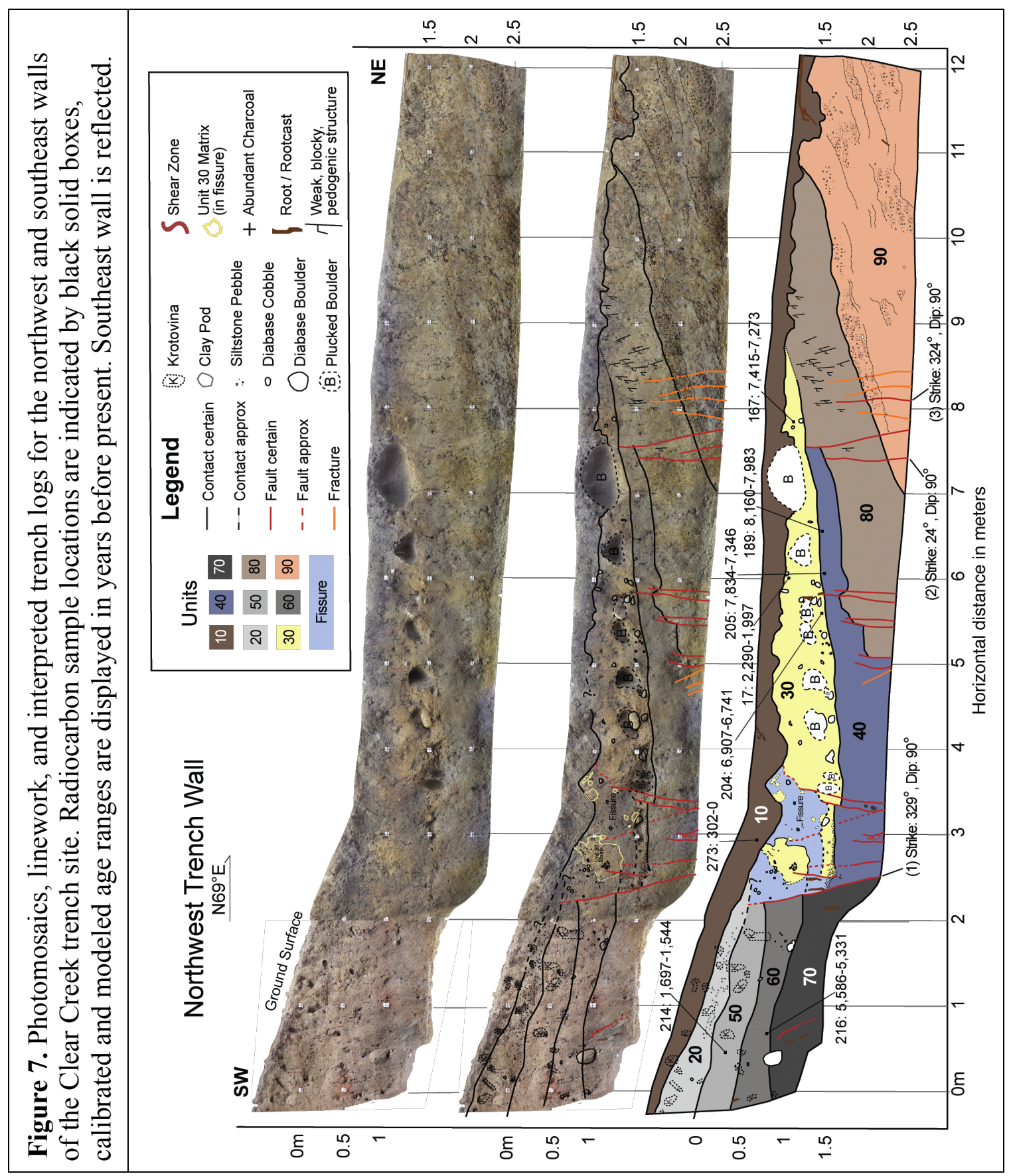




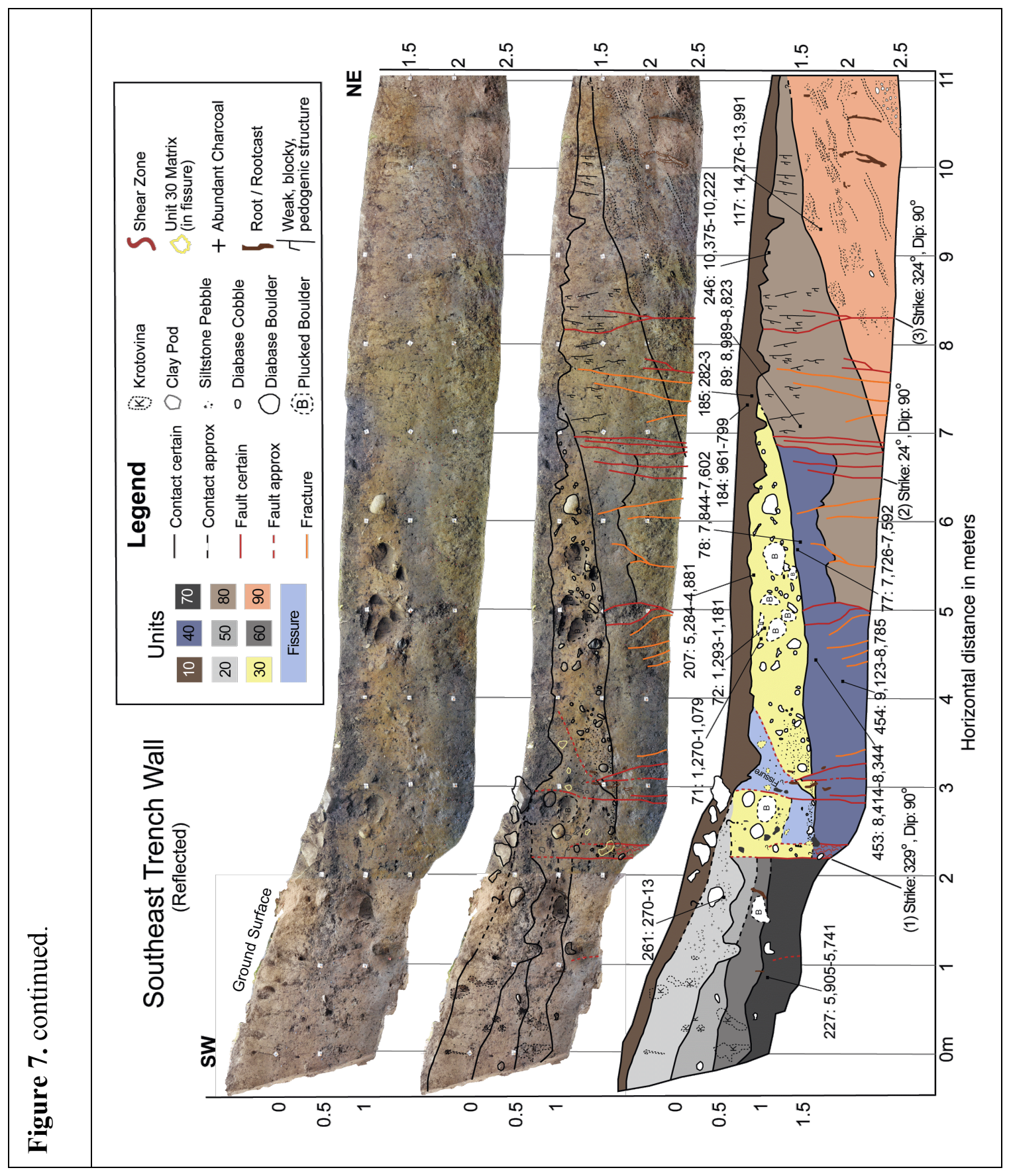


grading from top to bottom, lighter to darker, between $\mathrm{H} 3-\mathrm{H} 5$, to represent two periods of soil development with a pulse of sedimentation separating the two soil horizons.

Unit 30 is a dark yellowish brown silty clay $(80 \%)$ with boulders $(20 \%)$. Boulders are matrix supported, and fine upward, primarily resting on the basal contact with underlying units 40 and 80 . Boulders are sub-rounded to sub-angular diabase ranging from $\sim 2 \mathrm{~cm}$ to $\sim 0.5 \mathrm{~m}$ in diameter. The rest of the unit is made up of silty clay with ironrich pebbles. Unit 30 is located between meters $\mathrm{H} 2-\mathrm{H} 8$, and is $\sim 0.25 \mathrm{~m}$ to $1 \mathrm{~m}$ below the ground surface (Figure 7). Unit 30 has a sharp basal contact, and unconformably overlies units 40 and 80 . Unit 30 is interpreted to be slope-derived colluvium. Diabase boulders are sourced by the outcrops of 'Intrusive rocks of the Coast Range,' map unit Tis, as mapped by Wells et al. (2018), immediately upslope of the Clear Creek trench site (Figure 3). Sub-rounded to sub-angular diabase boulders reflect spheroidal weathering by exfoliation, rather than rounding as a function of transport (Wells et al., 2018)

Unit 10 is a dark brown, massive, silt with sparse angular pebbles. Unit 10 silt has granular pedogenic structure, abundant charcoal and roots, and is heavily bioturbated in places. It is the highest stratigraphic unit continuously exposed along the length of the trench. (Figure 7). The base of unit 10 is wavy and irregular; the basal contact is diffuse over 3-5 $\mathrm{cm}$ between meters $\mathrm{H} 0$ and $\mathrm{H} 2$, discontinuous and eroded between meters $\mathrm{H} 2-$ $\mathrm{H} 4$, and sharp between meters $\mathrm{H} 4$ and H12. Unit 10 is interpreted to be the modern soil A horizon.

\subsubsection{Units Southwest of Fault Zone}

Units 20,50,60, and 70 are mapped southwest of the fault zone, from meters H0 $-\mathrm{H} 2$ (Figure 7). These stratigraphic units do not visually correlate with the units mapped 
northeast of the fault zone. Contacts between these units are diffuse, and distinguished primarily based on texture and component percentages of weathered pebbles, decreasing stratigraphically downward.

The deepest and oldest stratigraphic unit on the southwest side of the trench is unit 70, a massive dark brown silty clay. Unit 70 silty clay contains $1 \%$ small, $1 \mathrm{~cm}$ to 3 cm sub-rounded and sub-prismoidal weathered light orange, tan, and pink siltstone pebbles, decreasing stratigraphically downward. Unit 70 is $1.5-2 \mathrm{~m}$ below the ground surface, and the base of the unit is not exposed.

Unit 60 is a massive dark yellowish brown silty clay overlying unit 70, with a diffuse basal contact over 5-10 cm. Unit 60 contains $\sim 7 \%$ sub-rounded and subprismoidal weathered light orange, tan, and pink siltstone pebbles, ranging in size from 1 $\mathrm{cm}$ to $3 \mathrm{~cm}$. Unit 60 is $\sim 1 \mathrm{~m}-1.5 \mathrm{~m}$ below the ground surface on the southwest side of the trench.

Unit 50 is a massive dark yellowish brown sandy silt, with a diffuse basal contact over $5-10 \mathrm{~cm}$. Unit 50 contains $\sim 10 \%$ sub-rounded and sub-prismoidal weathered light orange, tan, and pink siltstone pebbles, ranging in size from $1 \mathrm{~cm}$ to $3 \mathrm{~cm}$. Unit 50 is $\sim 0.5$ $\mathrm{m}-1 \mathrm{~m}$ below the ground surface on the southwest side of the trench, and has a course, granular texture.

Unit 20 is a yellowish-brown silt, containing abundant charcoal and $\sim 15 \%$ subrounded and sub-angular weathered light orange, tan, and pink siltstone pebbles, ranging in size from $1 \mathrm{~cm}$ to $3 \mathrm{~cm}$. The basal contact of unit 20 is irregular and diffuse over $1 \mathrm{~cm}$ to $3 \mathrm{~cm}$. The unit is granular with massive to single-grain structure, and is $0.25 \mathrm{~m}$ to 0.5 $\mathrm{m}$ below the ground surface. 


\subsection{Clear Creek Trench Structure}

The Clear Creek trench exposed a 1-1.5 m-wide fault zone between meters H2 and H4 (Figure 7). The fault zone consists of 6 to 8 sub-vertical fault strands (Figure 7). The fault zone juxtaposes colluvium of unit 30 (northeast of meter $\mathrm{H} 4$ ) with units 50, 60, and 70 (southwest of meter $\mathrm{H} 2$ ). Vertical faults and shears extend upward in units 40 and 80 , meters $\mathrm{H} 5-\mathrm{H} 8$ (Figure 7). The fault that truncates unit 40 has a $24^{\circ}$ strike and vertical dip (Figure 7). This strike is $73^{\circ}$ oblique to the $311^{\circ}$ striking primary fault trace mapped with lidar. The base of unit 40 is offset $\sim 20 \mathrm{~cm}$ to $0.5 \mathrm{~m}$ across vertical faults between meters H5 and H6 (Figure 7). Units southwest of the fault zone are sheared between meter H1, V1 - 1.5 (Figure 7).

\subsection{Deposit Age Estimates and Sedimentation Rates}

Abundant organic matter in the stratigraphic units at the Clear Creek site provides the framework for my OxCal stratigraphic age model. The oldest unit, 90, is constrained with one sample and is between 14,262-13,900 calendar years before present (cal B.P.) Unit 80 is $10,377-8,823$ cal B.P., and unit 40 is $8,940-6,852$ cal B.P. On the southwest end of the trench, units 70, 60, and 50, fall between 5,904-5740, 5,586-5,331, and 1,6981,544 cal B.P., respectively. Unit 30 is 1,293-1,063 cal B.P.; unit 20 is $280-64$ cal B.P., and unit 10 is 960-0 cal B.P. (Figure 8, Table 4, Appendix G). Appendix G contains ages of samples not included in the OxCal models because they were stratigraphically inconsistent (i.e. stratigraphically higher samples were older and vice versa). 
OxCal v4.3.2 Bronk Ramsey (2017); r:5 IntCal13 atmospheric curve (Reimer et al., 2013)

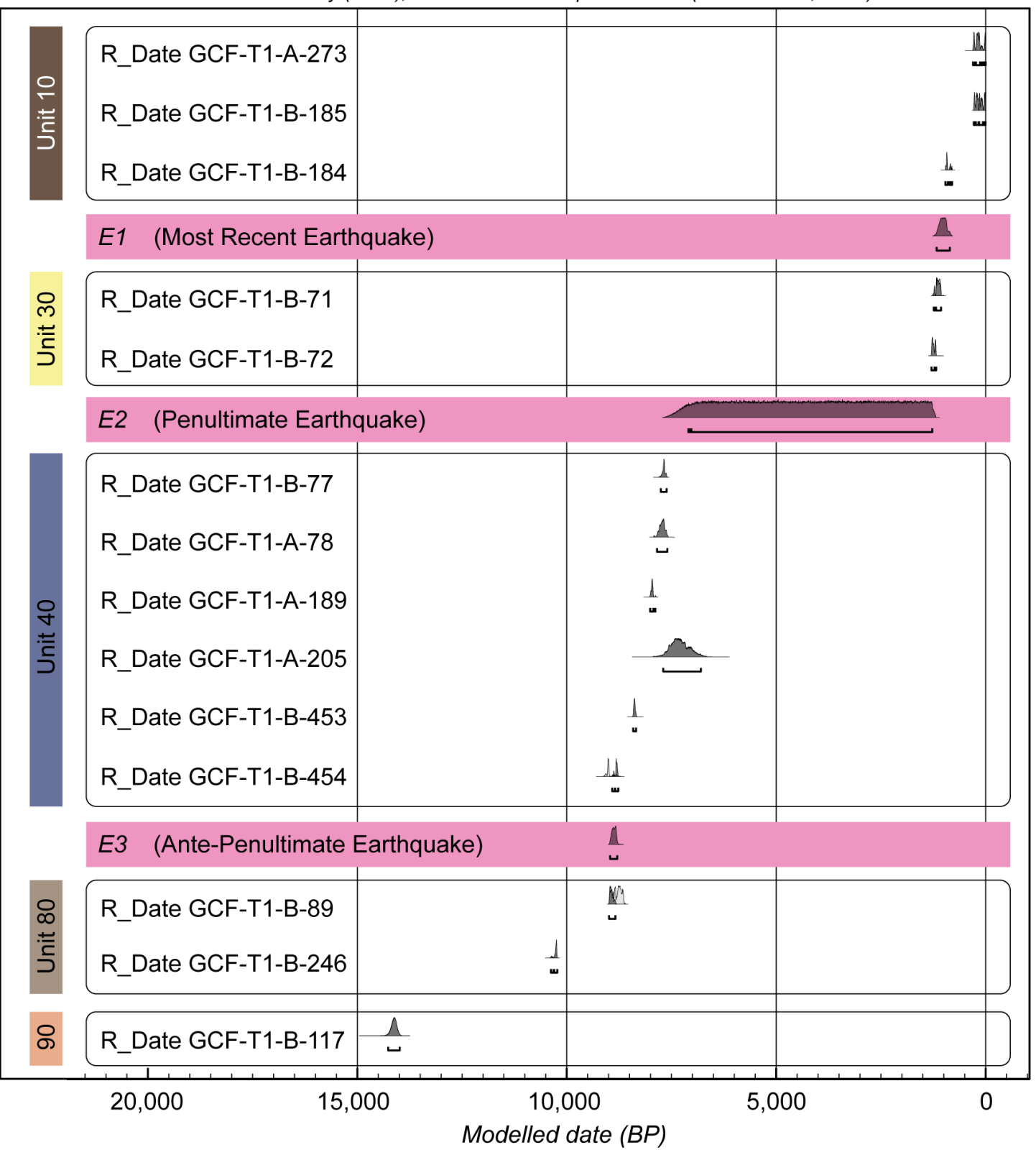

Figure 8. Summary of age results from stratigraphic ordering using OxCal Version 4.3 (Ramsey, 2017), showing probability density functions (pdf) for radiocarbon samples, with $2 \sigma$ uncertainty shown by the solid bar below the pdf. Prior pdfs are light gray (e.g. sample GCF-T1-B-89) and represent the pdf calibrated ages; posterior pdf's are shaded dark gray, these pdf's are trimmed with stratigraphic ordering information in OxCal. Modeled paleoearthquake Pdf's are highlighted by pink bars. 
Table 4. Radiocarbon results for detrital charcoal samples from the Clear Creek trench site. Samples listed in italic font were stratigraphically inconsistent and were not used in the Oxcal Model.

\begin{tabular}{|c|c|c|c|c|c|}
\hline Sample Number & $\begin{array}{l}\text { LLNL ID } \\
\text { Number }\end{array}$ & Unit & $d^{13} C^{*}$ & $\begin{array}{c}\text { AMS } \\
\text { Radiocarbon } \\
\text { Age (yr B.P.) } \\
\dagger \\
\end{array}$ & $\begin{array}{c}\text { Calibrated } \\
\text { Radiocarbon } \\
\text { Age (cal. B.P.) } \\
+ \\
\end{array}$ \\
\hline GCF-T1-A-273 & N121963 & \multirow{3}{*}{10} & -25 & $190 \pm 30$ & $302-0$ \\
\hline GCF-T1-B-184 & N121022 & & -24.0 & $995 \pm 25$ & $960-799$ \\
\hline GCF-T1-B-185 & N121021 & & -27.8 & $145 \pm 25$ & $282-3$ \\
\hline$G C F-T 1-B-261$ & N121964 & 20 & -25 & $105 \pm 30$ & $280-64$ \\
\hline$G C F-T 1-B-207$ & $N 121023$ & \multirow{6}{*}{30} & -25 & $4445 \pm 35$ & $5284-4881$ \\
\hline GCF-T1-B-71 & N121025 & & -29.0 & $1210 \pm 25$ & $1236-1063$ \\
\hline GCF-T1-B-72 & N121024 & & -25 & $1305 \pm 30$ & $1293-1181$ \\
\hline$G C F-T 1-A-17$ & $N 121026$ & & -29.5 & $2080 \pm 25$ & $2125-1990$ \\
\hline$G C F-T 1-A-167$ & N121029 & & -25.2 & $6400 \pm 25$ & $7415-7269$ \\
\hline$G C F-T 1-A-204$ & $N 121028$ & & -24.2 & $6000 \pm 25$ & $6911-6751$ \\
\hline GCF-T1-B-77 & N121034 & \multirow{6}{*}{40} & -22.4 & $6855 \pm 30$ & $7755-7615$ \\
\hline GCF-T1-B-78 & N121033 & & -25 & $6880 \pm 60$ & 7844-7601 \\
\hline GCF-T1-A-189 & N121031 & & -23.4 & $7135 \pm 25$ & $8010-7883$ \\
\hline GCF-T1-A-205 & N121030 & & -25 & $6420 \pm 220$ & $7735-6852$ \\
\hline GCF-T3-B-453 & N121965 & & -25 & $7565 \pm 30$ & $8414-8344$ \\
\hline GCF-T3-B-454 & N121966 & & -25 & $8075 \pm 35$ & $8940-8771$ \\
\hline GCF-T1-A-214 & N121967 & 50 & -25 & $1700 \pm 30$ & $1698-1544$ \\
\hline GCF-T1-A-216 & N121968 & 60 & -25 & $4750 \pm 30$ & $5586-5331$ \\
\hline GCF-T1-B-227 & N121969 & 70 & -25 & $5065 \pm 30$ & $5904-5740$ \\
\hline GCF-T1-B-89 & N121970 & \multirow{2}{*}{80} & -25 & $7940 \pm 30$ & $8989-8823$ \\
\hline GCF-T1-B-246 & N121036 & & -24.6 & $9130 \pm 25$ & $10377-10227$ \\
\hline GCF-T1-B-117 & N121971 & 90 & -25 & $12230 \pm 40$ & $14262-13900$ \\
\hline \multicolumn{6}{|c|}{$\begin{array}{l}\text { The quoted age is in radiocarbon years using the Libby half-life of } 5568 \text { years and following } \\
\text { the conventions of Stuiver and Polach (1977). }\end{array}$} \\
\hline \multicolumn{6}{|c|}{$\begin{array}{l}{ }^{\ddagger} \text { Radiocarbon ages calibrated using OxCal v.4.2.4 software (Bronk Ramsey, 2008, 2009), using } \\
\text { the IntCal13 atmospheric } \mathrm{CO}_{2} \text { calibration curve (Reimer et al., 2013) and reported with } 2 \sigma \text { error }\end{array}$} \\
\hline \multicolumn{6}{|c|}{$\begin{array}{l}* d^{13} \mathrm{C} \text { values are assumed values according to Stuiver and Polach }(1977, \text { p.355), without } \\
\text { decimals. Values measured for the material itself are given with a single decimal place }\end{array}$} \\
\hline
\end{tabular}


I calculated the sedimentation from an age-depth plot of ${ }^{14} \mathrm{C}$ samples collected from the Clear Creek trench (Figure 8) by separating the data into the two groups on either side of the fault zone. Units southwest of the fault zone (20,50,60, and 70) were grouped and a linear regression fit to the ${ }^{14} \mathrm{C}$ data yields a rate of $0.1 \mathrm{~mm} / \mathrm{yr}$., with a $\mathrm{R}^{2}$ value of 0.91. Samples northeast of the fault zone in units 10,30, 40, and sample 89 in unit 80 were grouped and yielded a sedimentation rate of $0.1 \mathrm{~mm} / \mathrm{yr}$., with a $\mathrm{R}^{2}$ value of 0.41. Samples 246 (unit 80) and 117 (unit 90) were excluded, as they are out of stratigraphic order based on their age in comparison to the rest of samples in the dataset. I calculated a sedimentation rate for samples in unit 40 , and a linear regression yielded a rate of $0.5 \mathrm{~mm} / \mathrm{yr}$. with a $\mathrm{R}^{2}$ value of 0.84 .

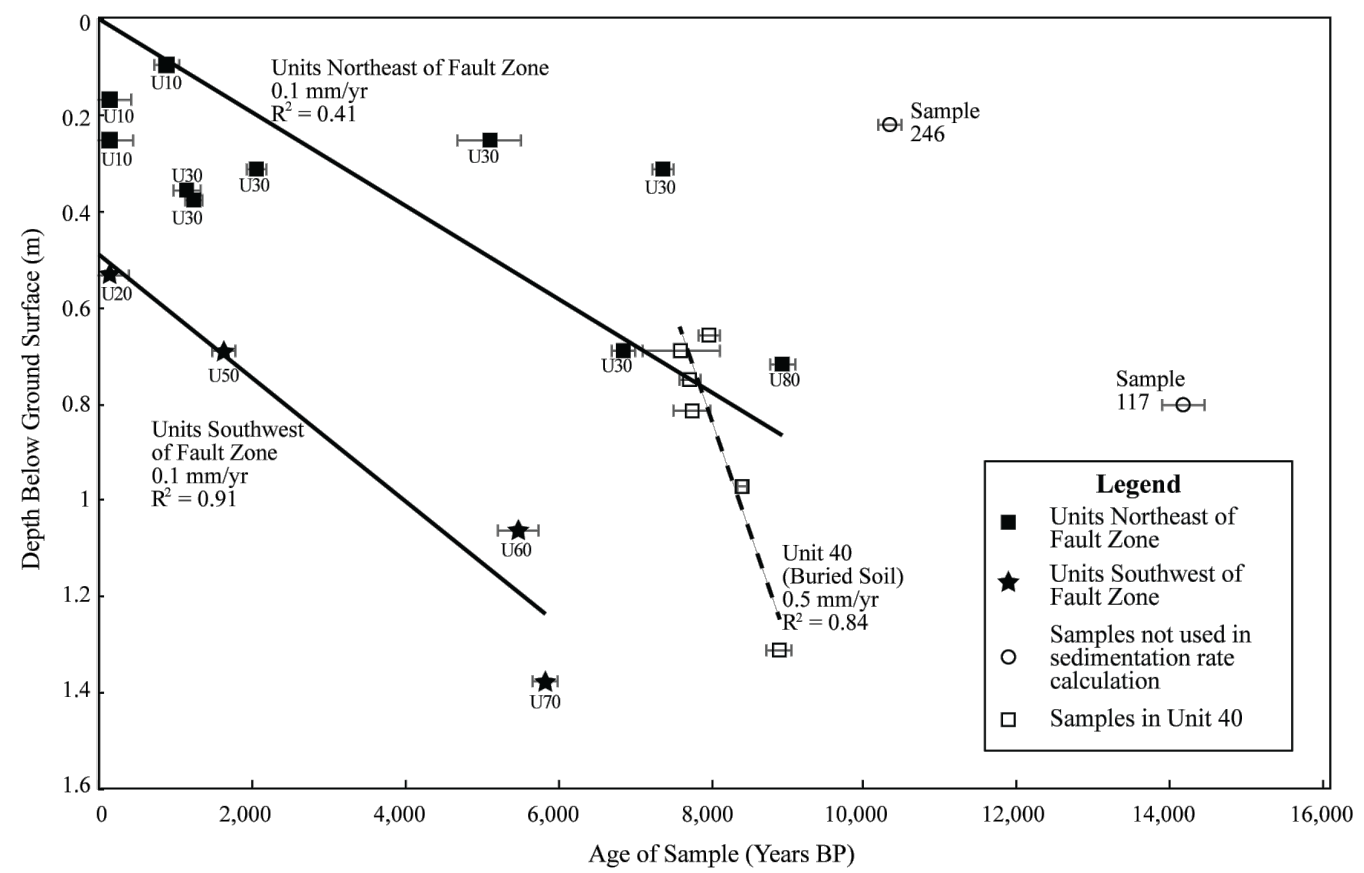

Figure 9. Scatter plot of calibrated radiocarbon ages versus stratigraphic depth below the ground surface. Sedimentation rates are calculated for samples southwest of the fault zone, northeast of the fault zone, and for unit 40. Open circles represent the two oldest samples excluded from the sedimentation rate calculation because tilting of the ground surface has made them stratigraphically higher than equivalent units just a few meters away. 


\subsection{Earthquake Evidence}

I find stratigraphic and structural evidence for three surface-rupturing earthquakes at the Clear Creek site (E1-E3). We also find weak evidence for one younger large magnitude earthquake, and weak evidence for older surface deformation.

\subsubsection{Event E1}

Evidence for E1 is expressed as two primary vertical fault strands that extend upward and truncate unit 30, between meters H2 and H4 (Figure 7). These faults displace units 30 and 40 and form a roughly $1 \mathrm{~m}$ long and $0.5 \mathrm{~m}$ deep fissure within unit 30 . The fissure fill contains intact soil clasts of unit 30 (Figure 7). Units 50, 60, and 70 are truncated by the southwestern most fault and juxtaposed in vertical fault contact against units 30 and 40. On the northwest wall in the hand-dug trench, cobbles in colluvial unit 30 are vertically aligned between fault traces at the southwest margin of the fissure (Figure 10, H2.7, V1).

\subsubsection{Event E2}

Unit 40, a well-developed soil, dips $\sim 10^{\circ}$ to the southwest and into the hillslope, vertically offset by $\sim 0.5 \mathrm{~m}$. This unit is truncated on the northeast end of the trench and in sub-vertical fault contact with unit 70 (Figure 7, H6 - H8). Numerous faults and fractures extend upward into units 40 and 80, terminating within or at the top of unit 40 (Figure 7). 


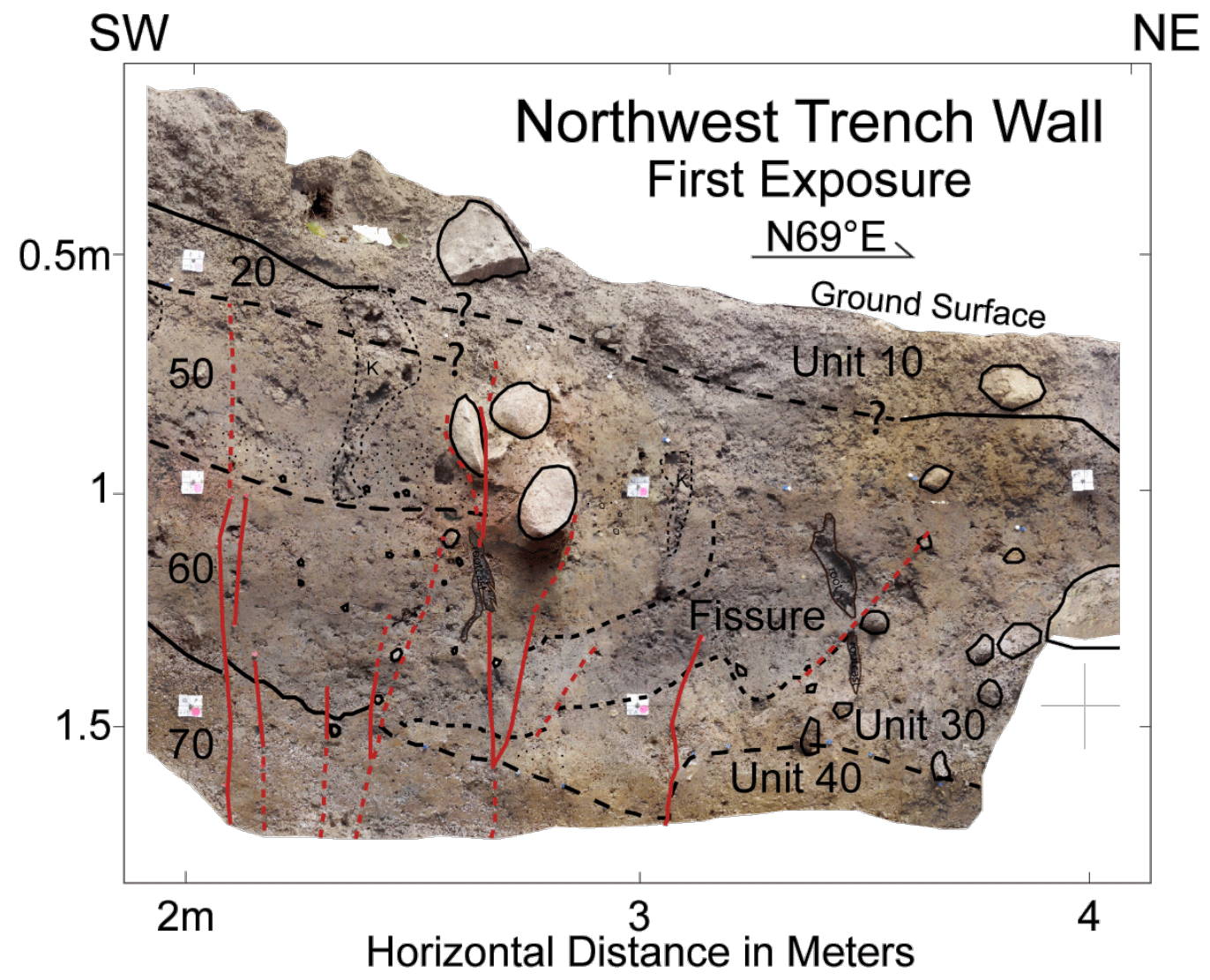

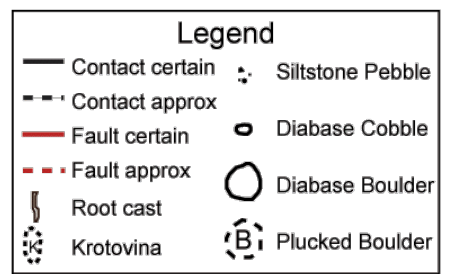

Figure 10. Photomosaic of meters $\mathrm{H} 2-\mathrm{H} 4$ exposed in the hand-dug trench, northwest wall. Three aligned cobbles are located between fault strands at meter $\sim \mathrm{H} 2.6$.

\subsubsection{Event E3}

Unit 40 thickens considerably from the northeast where it is $\sim 0.25 \mathrm{~m}$ thick to $~$ $>0.5 \mathrm{~m}$ thickness at the southwest (Figure 7, H2 - H7). A gradational color change is observed in unit 40 on the southeast wall (Figure 7, H2-5). Detrital charcoal age samples from this unit indicate rapid sedimentation (Figure 9). 


\subsubsection{Weak Evidence of Younger Surface Deformation}

A structural depression within unit 10, the modern A horizon, is observed on both trench walls between meters $\mathrm{H} 3$ and $\mathrm{H} 4$ (Figure 7). This $<0.2 \mathrm{~m}$ trough like depression aligns with and is nestled within the fissure associated with E1. The small trough is not clearly associated with any shears or faults, it may be an area of root throw or bioturbation. Angular diabase cobbles are mapped in place within unit 10 and exposed at the ground surface at the inflection in the hillslope, these are located on the northwest wall, meters H2 - H3 (Figure 10) and southeast wall, meters H2 - H3 (Figure 7). We list this as event E0 in Appendix F.

\subsubsection{Possible Earlier Deformation}

We map a reverse fault in the northeast extension V-Trench where unit 90 is stratigraphically thrust above stratigraphically younger diabase colluvium (Appendix E). It is stratigraphically unclear how displacement on this reverse fault relates to faulted stratigraphy within the primary fault zone from trench meters $\mathrm{H} 2-\mathrm{H} 8$ (Figure 7). 


\section{Discussion}

\subsection{Earthquake History}

\subsubsection{Event Interpretations}

Trench stratigraphy at the Clear Creek site reveals evidence for at least two Holocene surface deforming earthquakes, and weaker evidence for a third. Earthquake E2 occurred when unit 40, a well-developed soil, was at the ground surface (Figure 11a). E2 dropped unit 40 downward $1 \mathrm{~m}$ at meter $\mathrm{H} 2$ (Figure 7), and backtilted unit $40 \sim 15^{\circ}$ to the southwest into the hillslope (Figure 11b). Accommodation space was created where unit 40 was down-dropped and back-tilted was in-filled by rocky colluvial unit 30. Diabase boulders are abundant along the base of the unit and are flat-lying on the contact with underlying unit 40 (meters H2.5 - H8.5) (Figure 7 and 10c). The size range and abundance of these diabase boulders is unique to colluvial unit 30, other units are finergrained and generally contain siltstone clasts. I interpret a change in deposition, and infer these boulders to be a gravity driven deposit from steep hillslopes above the fault-bound, side-hill bench, that were loosened and transported by strong ground motions from E2.

E1, which occurred after E2, faulted the rocky colluvial unit 30, and opened an upward-terminating fissure within the colluvial deposit (meters H2 - H4) (Figure 7 and 10d). Subvertical fault splays activated by this large earthquake extend upward into unit 30. Vertically aligned cobbles on the margin of the fissure (meters H2 - H3, Figure 10) (meters H3 - H4, Figure 7) were moved laterally and tilted into this upright position during E2.

There is weaker evidence for a third earthquake, E3, within unit 40 that is older than E2. Unit 40 is a soil developed on unit 80 from meters $\mathrm{H} 5-\mathrm{H} 7$, and it is $\sim 0.25 \mathrm{~m}$ 
thick (Figure 7). Unit 40 is interpreted as a marsh soil from meters $\mathrm{H} 2-\mathrm{H} 5$, and is $>0.5$ $\mathrm{m}$ thick. When this soil was at the surface, it likely looked similar to the marsh mapped a few meters north of Clear Creek trench site (Figure 3b). On the southeast wall, the gradational coloring in unit 40 from light brown at the top to darker gray at the bottom suggests two soil horizons (Figure 7, meters H5 - H7), which is representative of a stable surface with moderate soil development and subsequent deposition followed by further soil development. ${ }^{14} \mathrm{C}$ ages from the unit reveal relatively rapid sedimentation within unit 40 of $0.5 \mathrm{~mm} / \mathrm{yr}$. (Figure 9). Rock uplift and erosion rates do vary systematically across the Coast Range (Kobor and Roering, 2004). However, the uplift rate of the central Coast Range mountains is $0.1-0.3 \mathrm{~mm} / \mathrm{yr}$. (Personius et al., 1995), which coincides with the 0.1 $\mathrm{mm} / \mathrm{yr}$. sedimentation rate calculated for all other samples in the Clear Creek trench (Figure 9). The observed higher sedimentation rate for unit 40supports the existence of E3, in which deformation down-dropped the ground surface and created accommodation space which was slowly infilled by fine-grained marsh deposits of unit 40 . The creation of accommodation space in the same region was also observed for E2, though this deformation was infilled by a colluvial deposit. A deeper, benched trench could reveal the base of unit 40 and its stratigraphic relationship with unit 80 at depth.

\subsubsection{Earthquake Timing}

Earthquake ages were estimated with ${ }^{14} \mathrm{C}$ data from detrital charcoal samples within each stratigraphic unit. With detrital charcoal, the youngest dates from a given unit generally best reflect the maximum age of that deposit. Charcoal samples were large, abundant, and angular, suggesting minimal erosion and rounding from transport and a local ${ }^{14} \mathrm{C}$ source. I infer samples are not re-worked and are sourced from local fire events. 
Samples are likely older than the deposit, though given the sample abundances, size and angularity they likely have minimal inherited age due to long residence time in the landscape prior to deposition.

To evaluate earthquake timing, I created a probabilistic model using OxCal Bayesian analysis (v.4.3.2; Bronk-Ramsey, 2017). OxCal models the timing of events by weighing the ${ }^{14} \mathrm{C}$ ages in stratigraphic order (Bronk Ramsey, 2008; Leinkaemper and Bronk Ramsey, 2009) and yields earthquake timing probability density functions (PDFs). I initially included all 27 samples from Clear Creek site in the OxCal model, but in evaluating the results I eliminated outliers that did not fit within the model stratigraphically. See Appendix $\mathrm{G}$ for sample ${ }^{14} \mathrm{C}$ ages not included in the preferred OxCal model (Figure 8).

My preferred earthquake OxCal model for the Clear Creek site constrains E1 between units 10 and 30 (1,169-854 cal. B.P.), E2 between units 30 and 40 (7,095-1,273 cal. B.P.), and $\mathrm{E} 3$ between units 40 and $80(8,963-8,796$ cal B.P.) with $2 \sigma$ uncertainty (Figure 8). This preferred model excludes units 50, 60, and 70, because there is no structural evidence for earthquakes between these units and stratigraphy does not clearly correlate with deposits northeast of the fault zone (Figure 7, Figure 8). The calibrated and modeled radiocarbon ages of ${ }^{14} \mathrm{C}$ samples demonstrate a gradual increase in age from unit 10 to unit 90 with larger time gaps between units 50 and 60, and units 80 and 90 (Table 4, Figure 8). Units 50,60, and 70, southwest of the fault zone, correlates in age with unit 30, northeast of the faults. Unit 30 was deposited immediately after E2 and all ${ }^{14} \mathrm{C}$ age distributions collected from this unit should be closely spaced in time. However, charcoal ${ }^{14} \mathrm{C}$ ages had a wide range from this unit (Table 4) suggesting either some amount of 
residence time in the landscape prior to deposition or that charcoal may be from a longlived tree species and could have a large in-built ${ }^{14} \mathrm{C}$ age if the sample was sourced deep within the tree (e.g. Gavin, 2001). As a result of this, I only include the youngest samples from the unit, charcoal samples 71 and 72 , see Appendix G for a stratigraphic sequence OxCal model with no earthquakes for all ${ }^{14} \mathrm{C}$ samples analyzed for the site, including those excluded from our preferred and alternate earthquake models because they were out of stratigraphic order. Appendix $\mathrm{H}$ is an alternate earthquake OxCal model with event E2 placed between units 50 and 60 . We correlate stratigraphy on the southwest (unit 50, 60 $\& 70$ ) and northeast (units $30 \& 40$ ) sides of the fault zone based solely on unit ages unit 50 is very close in age to unit 30 , and units 60 , and 70 are substantially older than unit 30 , the event horizon for E2. This alternate model places E2 between units 50 and 60 because there is a large time hiatus between units 50 and 60 , suggestive of an unconformity (nondeposition or erosion), disrupting steady sedimentation. 

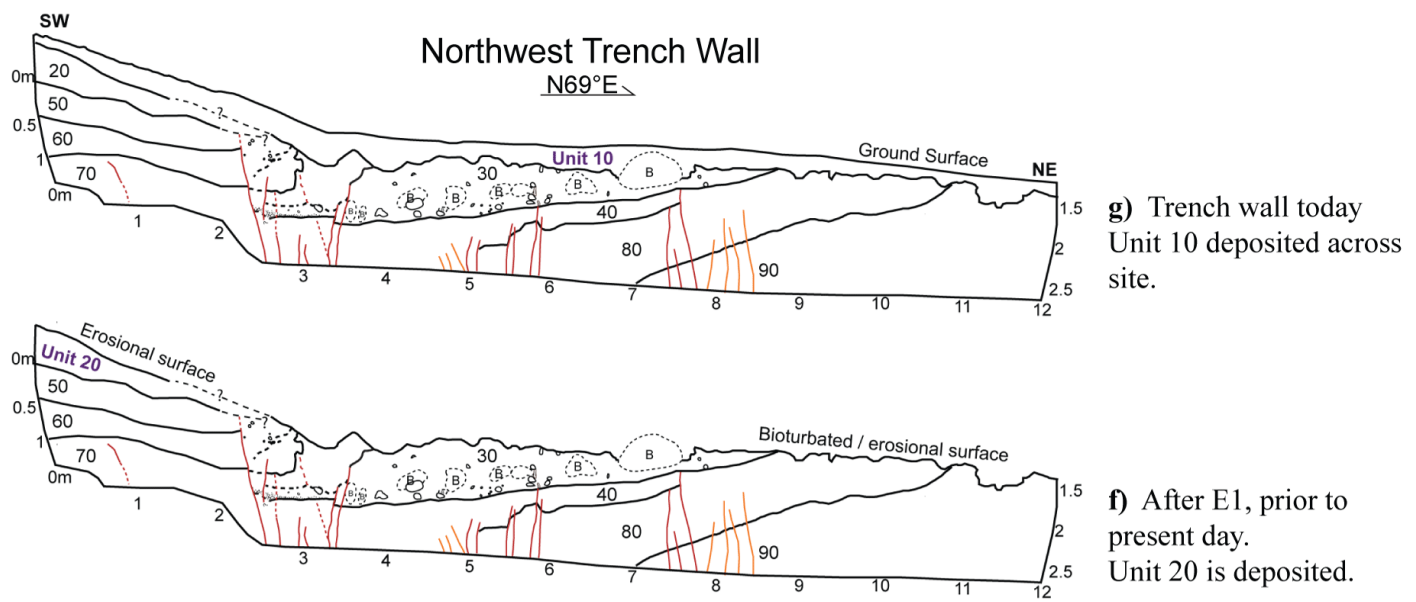

f) After E1, prior to present day.

Unit 20 is deposited.

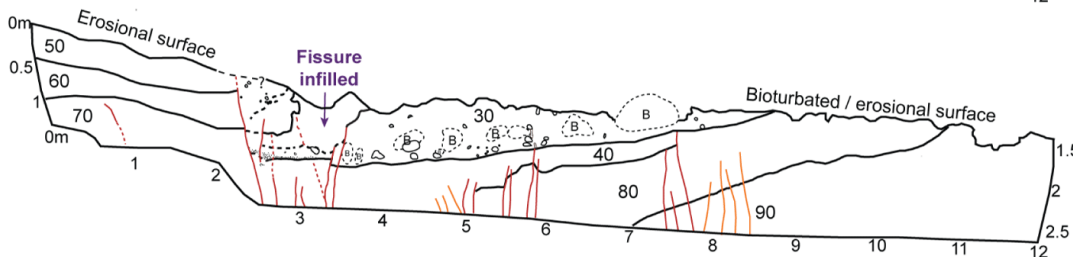

e) Immediately fter E1.

E1 Fissure infilled with clasts of surrounding units.

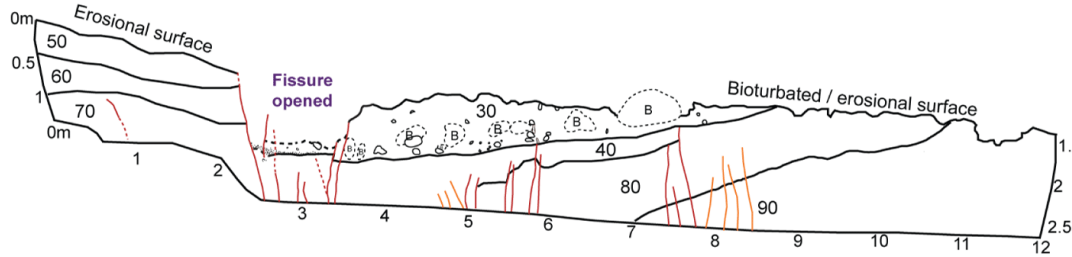

d) E1: (1,169-854 cal. B.P.) Fault truncates units 50,60, and 70 , and displaces colluvium of unit 30 . Fissure extends to ground

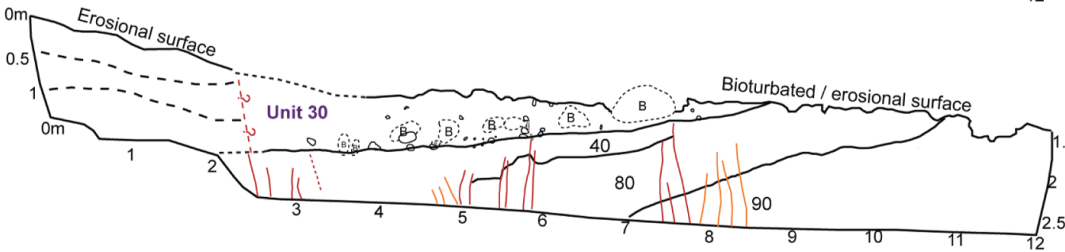
surface.

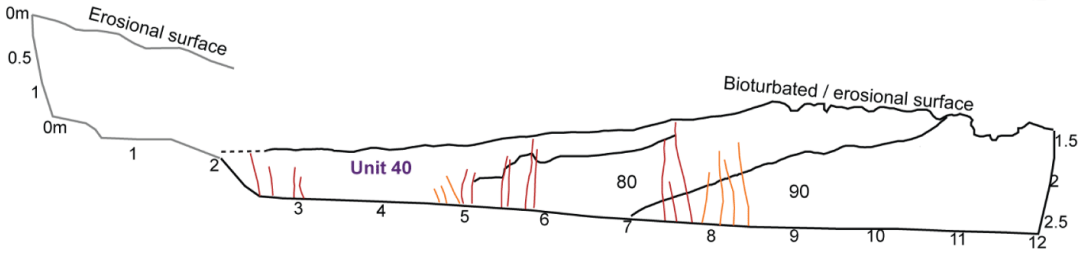

c) Immediately after E2. Colluvial unit 30 is deposited into accomodation space above unit 40

b) E2: (7,095-1,273 cal B.P.) Unit 40 is back-tilted into the hillslope

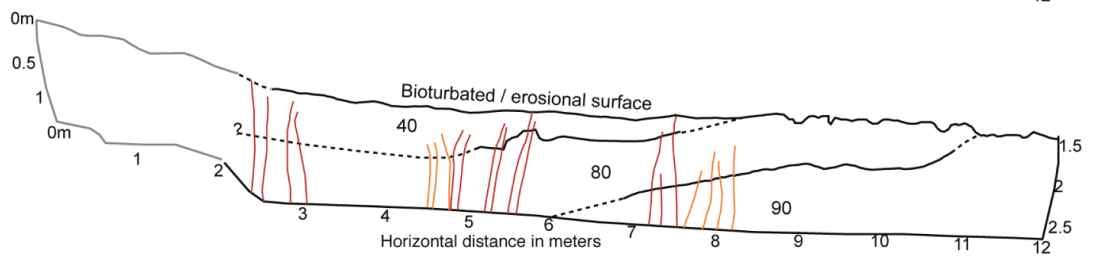

a) Prior to E2.

Unit 40 is at the ground surface

Figure 11. Schematic reconstruction of vertical deformation from earthquakes E1 and E2 created by incrementally retro-deforming the northwest trench $\log$. In a and b of the sequence, units southwest of the fault zone are younger than units 40 and 80, so trench wall outline is left in gray for reference. Unit lines become un-dashed after E1 occurs. This reconstruction does not address lateral slip, only the vertical component of deformation. 


\subsubsection{Evidence of Younger Deformation (E0)}

I find weak evidence for surface disturbance after E1, based on a small depression $\sim 30 \mathrm{~cm}$ wide and $\sim 15 \mathrm{~cm}$ deep within unit 10, observed on both trench walls (Figure 7, $\mathrm{H} 3$ - H3.5). I also observe large, angular diabase cobbles buried just below the surface at the hillslope inflection (Figure 7, H2 - H3). There are no younger deposits above this depression, and soil above the cobbles is heavily bioturbated (Figure 7, $\mathrm{H} 3-\mathrm{H} 3.5$ ). Boulders at the site are all diabase, and are sourced upslope of the trench from Intrusive rocks of the Coast Range (geologic unit Tis) (Figure 3a). I interpret the presence of boulders and cobbles in the deposits to be related to destabilization from ground acceleration from an earthquake, or from other non-tectonic rockfall processes. Because I only see boulders and cobbles in one older deposit (unit 30), associated with E2, it is likely the cobbles within unit 10 are evidence of ground acceleration.

I consider the depression and presence of diabase cobbles weak evidence of a younger surface deforming event. However, it is also possible that deposition of large cobbles could have resulted from a large magnitude earthquake along the GCF at another location, where widespread ground motions were also felt at Clear Creek site, but little to no surface deformation occurred. Land use changes such as logging could have uprooted boulders in this area. I also consider the possibility that the Tillamook Burn of 1933 and also 1939 and 1945 in the northern Oregon Coast Range (Neiland, 1958) could have caused trees to come down and root throw could result in such a depression.

\subsubsection{Evidence of Older Deformation (EE)}

I find evidence for reverse faulting on the GCF within stratigraphy of the Vtrench; unit 90 is found stratigraphically above diabase colluvium (Appendix C). Diabase 
is also present in unit 30 as gravity-driven colluvium, as a result of E2. It is likely the diabase found stratigraphically below the reverse fault in the V-trench is there as a result of a surface-rupturing earthquake. There was not abundant charcoal found in the walls of the V-trench, so there is no way to constrain the timing of this event.

Interbeds of the Yamhill Fm. colluvium, unit 90 , are tilted $\sim 20-30^{\circ}$ to the southwest (Figure 7). After retrodeformation, unit 90 remains tilted $\sim 10^{\circ}$ to the southeast (Figure 11). Earlier surface-deforming earthquakes on the GCF likely caused the southwest tilt of this stratigraphic unit. E1 and E2 caused a $\sim 10^{\circ}$ tilt in units 40,80 , and 90, after retrodeforming the $\sim 10^{\circ}$ tilt from E1 and E2, I find that the unit is still tilted 10$20^{\circ}$ to the southwest (Figure 11). Assuming each earthquake tilted the ground surface the same amount, roughly $5^{\circ}$ to the southwest, this indicates there were at least two additional earlier surface deforming earthquakes that tilted unit 90 . Unit 90 lacked abundant organic material and stratigraphic resolution to evaluate the timing of earlier events.

\subsection{Paleoearthquake Magnitude, Rupture Length, and Displacement Estimates}

Using empirical scaling relationships from Wells and Coppersmith (1994), I calculate the maximum earthquake magnitude the GCF could produce. If the entire $73 \mathrm{~km}$ length of the fault were to rupture, the result would be a Mw 7.2 earthquake, based on the regression for a strike-slip fault (Table 2). Using regressions from Hanks and Bakun (2002) I used fault rupture area to calculate another magnitude estimate for a strike slip fault; for a $20-\mathrm{km}$ fault depth, the resulting earthquake would be a Mw 7.3, and for a 25$\mathrm{km}$ fault depth, a Mw 7.4. Though this is much larger than historic crustal earthquakes in the region which have been $<6 \mathrm{Mw}$ (Thomas et al., 1996), it is consistent with estimates 
of crustal earthquake potential along the St. Helens seismic zone in Washington State (Weaver, 1983). Though considerable attention has been given to risk associated with subduction zone earthquakes in the PNW (e.g. Raghunandan et al., 2015; Petersen et al., 2002), my results highlight that $>\mathrm{Mw} 7$ crustal earthquakes also pose significant risk for the Portland Metropolitan area and should be taken into account by regulators and developers.

The GCF is primarily a right-lateral strike-slip fault (Wells et al., 2009) and relationships between surface rupture length and lateral displacement reveal that for a 73$\mathrm{km}$ strike-slip rupture, average displacement is $1.7 \mathrm{~m}$ (Table 2) (Wells and Coppersmith, 1994). However, evidence for reverse faulting on nearby structures, and my observation of a reverse fault in the V-trench (Appendix C) indicate paleoearthquakes on the GCF also have a component of vertical motion. I observe $0.5 \mathrm{~m}$ of vertical offset in E2, measured from across the top of unit 40 from the northeast-most end to where that plane intersects the fissure. With empirical scaling relationships, I calculate a lateral to vertical slip ratio by dividing average lateral displacement of $1.7 \mathrm{~m}$ (Table 2) (Wells and Coppersmith, 1994), by vertical displacement, $0.5 \mathrm{~m}$ from E2; yielding a lateral to vertical ratio of 3.4 to 1 .

My results indicate the intervals between large earthquakes at the Clear Creek site are 3,173 years between E1 and E2, and 4,695 years between E2 and E3. The average recurrence interval between paleoearthquakes that ruptured the surface at the Clear Creek site is 3,934 years during the past $10 \mathrm{ka}$. The minimum age constraints on E1, E2, and E3, gives recurrence between earthquakes of 419 years and 7,523 years. Using the maximum age constraints, the intervals are 5,926 and 1,868 years. Preliminary estimates of long- 
term slip rates on the GCF are $0.24 \mathrm{~mm} / \mathrm{yr}$. since $50 \mathrm{Ma}$ and $0.6 \mathrm{~mm} / \mathrm{yr}$. since $15 \mathrm{Ma}$ (Wong et al., 2000; R.E. Wells, personal comm.). In these estimates, the GCF is considered an independent fault segment that failed in repeats of the same size earthquake and released all built up strain. I compare the average recurrence interval (3,934 years) to the expected recurrence for the GCF, calculated by dividing the expected lateral slip per event, $1.7 \mathrm{~m}$ (Wells and Coppersmith, 1994) by the fault slip rate, 0.6 $\mathrm{mm} / \mathrm{yr}$., which gives a lower, but comparable recurrence of 2,833 years.

Using the $0.6 \mathrm{~mm} / \mathrm{yr}$. slip rate, I calculate the amount of slip that built up between events, and was likely released in a large earthquake. Between E2 and E3 there is an average interval of 4,695 years, which would result in $2.8 \mathrm{~m}$ of expected lateral displacement. Between E1 and E2 there is an interval of 3,173 years, which results in and expected $1.9 \mathrm{~m}$ of lateral slip.

\subsubsection{Right-laterally deflected drainages}

Along the northern GCF (Figure 2b, Table 3) Gales Creek is offset 753m, Bateman Creek 1,966m, Iler Creek (minimum) 1,615m, and Parson's Creek 1,459m. Based on $0.6 \mathrm{~mm} / \mathrm{yr}$. slip rate, the time it took for these streams to deform is $1.3 \mathrm{~m} . \mathrm{y} ., 3.3$ m.y., 2.7 m.y., and 2.5 m.y., respectively. This suggests that Coast Range topography has existed and the GCF has been active since at least 3.3 Ma. It also indicates the streams are likely much younger than the Coast Range itself, which likely emerged as a continuous subaerial topographic feature sometime in the early to mid-Miocene based on a transition from marine to marginal-marine and continental sedimentary rocks in the Astoria Basin (Niem et al., 1992; Armentrout, 1983). Stream offsets become progressively shorter to the north, which suggests the fault is younger to the north or it 
has repeatedly greater displacements on the southern end. It could also indicate that the age of streams decreases to the north.

\subsection{Regional Fault Implications}

My results indicate the GCF is a northwest-trending, Holocene active fault. The other northwest-trending bedrock faults mapped in the region such as the Portland Hills, Oatfield, East Bank, Lackamas Lake, Bolton, and Canby-Molalla faults are experiencing the same regional stresses, due to the clockwise rotation of the PNW relative to stable North America (Wells and McCaffrey, 2013; Brocher et al., 2017). It is likely that other northwest-trending faults in the Portland region have also produced surface rupturing earthquakes in the Holocene, based on sense of motion of these faults and regional principal stresses. The Portland Hills, Oatfield, and East Bank faults are analogous to the GCF, but run through downtown Portland, Oregon. A surface-rupturing earthquake on one of these faults could be catastrophic for millions of people living in the Portland metropolitan area (Tesfamariam and Wang, 2011; Raghunandan et al., 2015). 


\section{Conclusions}

I present a seismic source characterization that highlights northwest trending strike-slip faults with a reverse component in the forearc of Cascadia in northwest Oregon. The Gales Creek fault is the largest of these northwest-trending strike-slip crustal faults, and it is accommodating clockwise rotation and northward migration of the Oregon coast block resulting from oblique subduction of the Juan de Fuca plate.

Paleoseismic results from the Clear Creek trench site reveal the GCF has produced at least three surface-rupturing earthquakes in the Holocene. E1 occurred between 1,169 and 854 years B.P. and E2 between 7,095 and 1,273 years B.P., and E3 between 8,963 and 8,796 years B.P. with $2 \sigma$ uncertainty. Older colluvial stratigraphy suggests stratigraphic evidence for additional events. My results suggest the recurrence interval between large magnitude earthquakes is approximately 3,934 years at the Clear Creek site. The GCF is $73-\mathrm{km}$ long, and using empirical scaling relationships, if the full length of the fault were to rupture, the result would be a Mw 7.2 earthquake, which could cause significant damage to structures in the Portland metropolitan area.

Low slip rates over the broad mountainous PNW result in low slip accumulation on individual structures. Subdued geomorphic expression that is quickly eroded or obscured in this region by heavy rainfall and thick vegetation makes it difficult to identify active structures. Holocene activity on the GCF documented in this study provides an analog for other bedrock faults in the forearc of Cascadia and suggests that they too represent active seismic sources. 


\section{References}

Armentrout, J. M. (1983). Correlation of Cenozoic stratigraphic units of western Oregon and Washington. Geol. Soc. Amereica Spec. Paper, (184), 137-148.

Balsillie, J. H., \& Benson, G. T. (1971). Evidence for the Portland Hills Fault: The Ore Bin, v. 33.

Beeson, M.H., K.R. Fecht, S.P. Reidel, and T.L. Tolan (1985). Regional correlations within the Frenchman Springs Member of the Columbia River Basalt Group: New insights into the middle Miocene tectonics of northwestern Oregon, Oregon Geology, 47 no. 8, 87-96.

Beeson, M.H., T.L. Tolan, and J.L. Anderson (1989). The Columbia River Basalt Group in western Oregon; geologic structures and other factors that controlled flow emplacement patterns. Reidel, SP and Hooper, PR, Volancism and Tectonism in the Columbia River Flood-Basalt Province, Spec Pap Geol Soc Am, 239, 223-246.

Beeson, M.H., T.L. Tolan, and I.P. Madin (1991). Geologic map of the Portland quadrangle, Multnomah and Washington Counties, Oregon, and Clark County, Washington, State of Oregon, Department of Geology and Mineral Industries.

Blakely, R.J., K. Cruikshank, K, A. Johnson, M. Beeson, K. Walsh, and R.E. Wells (1997). A gravity study through the Tualatin Mountains, Oregon-Understanding crustal structure and earthquake hazards in the Portland urban area: Geological Society of America Abstracts with Programs, 29, no. 5, 5.

Blakely, R. J., R.E. Wells, T.L. Tolan, M. H. Beeson, A.M. Trehu, and L.M. Liberty (2000). New aeromagnetic data reveal large strike-slip (?) faults in the northern Willamette Valley, Oregon, Geol. Soc. Am. Bull. 112, no. 8, 1225-1233, doi: https://doi.org/10.1130/0016-7606(2000)112<1225:NADRLS>2.0.CO;2.

Blakely, R. J., R.E. Wells, T.S. Yelin, I.P. Madin, and M.H. Beeson (1995). Tectonic setting of the Portland-Vancouver area, Oregon and Washington: Constraints from low-altitude aeromagnetic data, Geol. Soc. Am. Bull. 107 no. 9, 1051-1062, doi: https://doi.org/10.1130/0016-7606(1995)107<1051:TSOTPV>2.3.CO;2.

Brocher, T. M., R. E. Wells, A. P. Lamb, and C. S. Weaver (2017), Evidence for distributed clockwise rotation of the crust in the northwestern United States from 
fault geometries and focal mechanisms, Tectonics, 36, 787-818, doi:10.1002/2016TC004223.

Bronk Ramsey, C., (2008). Deposition models for chronological records, Quaternary Sci. Rev. 27 no. 1-2, 42-60.

Bronk Ramsey, C. (2009). Bayesian analysis of radiocarbon dates, Radiocarbon 51 no. 1, $1,337-360$.

Burbank, D.W., and R.S. Anderson (2011). Tectonic geomorphology, John Wiley \& Sons, New Jersey, 54-55

Carlson, B.M., E.R. Schermer, C.B. Amos, W.J. Stephenson, B.L. Sherrod, and S.A. Mahan. (2018) Holocene Fault Reactivation in the Eastern Cascades, Washington Holocene Fault Reactivation in the Eastern Cascades, Washington, Bull. Seismol. Soc. Am. 108 no. 5A, 2614-2633.

Evarts, R.C., J.E. O'Connor, R.E. Wells, and I.P. Madin (2009). The Portland Basin: A (big) river runs through it, GSA Today, 19 no. 9, 4-10.

Fleck, R.J., Hagstrum, J.T., Calvert, A.T., Evarts, R.C., and Conrey, R.M., (2014) 40Ar/39Ar geochronology, paleomagnetism, and evolution of the Boring volcanic field, Oregon and Washington, USA: Geosphere, v. 10, no. 6, p. 1283-1314.

Gavin, D.G. (2001). Estimation of Inbult Age in Radiocarbon Ages of Soil Charcoal for Fire History Studies: Radiocarbon, 43, 27-44.

Geomatrix Consultants, Inc., (1995). Seismic design mapping, State of Oregon: Technical report to Oregon Department of Transportation, Salem, Oregon, under Contract 11688, January 1995, unpaginated, 5 pls., scale 1:1,250,000.

Hart, D. H., \& Newcomb, R. C. (1965). Geology and ground water of the Tualatin Valley, Oregon (No. 1697). USGPO,.

Hanks, T.C., and W.H. Bakun (2002). A bilinear source-scaling model for M-log A observations of continental earthquakes, Bull. Seismol. Soc. Am. 92 no. 5, 18411846.

Hyndman, R.D., S. Mazzotti, D. Weichert, and G.C. Rogers, (2003). Frequency of large crustal earthquakes in Puget Sound-Southern Georgia Strait predicted from 
geodetic and geological deformation rates. $J$ Geophys Res B Solid Earth Planets 108 no. B1, 2033 doi:10.1029/2001JB001710

Kobor, J.S. and J.J. Roering, (2004). Systematic variation of bedrock channel gradients in the central Oregon Coast Range: implications for rock uplift and shallow landsliding. Geomorphology, 62 no. 3-4, 239-256, doi: https://doi.org/10.1016/ j.geomorph.2004.02.013

Liberty, L.M., M.A. Hemphill-Haley, and I.P. Madin (2003). The Portland Hills Fault: uncovering a hidden fault in Portland, Oregon using high-resolution geophysical methods, Tectonophysics, 368 no. 1-4, 89-103, doi: https://doi.org/10.1016/S00401951(03)00152-5.

Liberty, L.M., A.M. Trehu, R.J. Blakely, and M.E. Dougherty (1999). Integration of high-resolution seismic and aeromagnetic data for earthquake hazards evaluations-An example from the Willamette Valley, Oregon, Bull. Seismol. Soc. Am. 89, no. 6, 1473-1483.

Madin, I.P. (1990). Earthquake-hazard geology maps of the Portland metropolitan area, Oregon-Text and map explanation: State of Oregon, Department of Geology and Mineral Industries Open-File Report 0-90-2, 21 p., 8 pls., scale 1:24,000.

McCaffrey, R., R.W. King, S.J. Payne, and M. Lancaster (2013). Active tectonics of northwestern US inferred from GPS-derived surface velocities, $J$ Geophys Res $B$ Solid Earth Planets 118 no. 2, 709-723, doi:10.1029/2012JB009473.

McCaffrey, R. (1994), Global variability in subduction thrust zone-fore arc systems: Pure and Applied. Geophysics, 142, 173-224.

McPhee, D.K., V.E. Langenheim, R.E. Wells, and R.J. Blakely (2014). Tectonic evolution of the Tualatin basin, northwest Oregon, as revealed by inversion of gravity data: Geosphere. 10, no. 2, 264-275, doi: https://doi.org/10.1130/ GES00929.1https://doi.org/10.1130/GES00929.1.

Neiland, B. (1958). Forest and Adjacent Burn in the Tillamook Burn Area of Northwestern Oregon. Ecology, 39 no. 4, 660-671, doi:10.2307/1931606

Niem, W.A., A.R. Niem, and P.D. Snavely (1992). Early and Mid-Tertiary oceanic realm and continental margin - western Washington-Oregon coastal sequence: The 
Cordilleran Orogen: Conterminous U.S.: Geological Society of America The Geology of North America, G-3, p. 265-270.

Personius, S.F. (1995). Late Quaternary stream incision and uplift in the forearc of the Cascadia subduction zone, western Oregon. J Geophys Res B Solid Earth Planets, 100 no. B10 20193-20210, doi: https://doi.org/10.1029/95JB01684

Personius, S.F., compiler, 2002, (1) Fault number 715, Beaverton fault zone, in Quaternary fault and fold database of the United States: U.S. Geological Survey website, https://earthquakes.usgs.gov/hazards/qfaults, accessed 03/25/2019 03:59 PM.

Personius, S.F., compiler, 2002, (2) Fault number 874, Bolton fault, in Quaternary fault and fold database of the United States: U.S. Geological Survey website, https://earthquakes.usgs.gov/hazards/qfaults, accessed 03/25/2019 03:45 PM.

Personius, S.F., compiler, 2002, (3) Fault number 716, Canby-Molalla fault, in Quaternary fault and fold database of the United States: U.S. Geological Survey website, https://earthquakes.usgs.gov/hazards/qfaults, accessed 03/25/2019 03:50 PM.

Personius, S.F., compiler, 2002, (4) Fault number 876, East Bank fault, in Quaternary fault and fold database of the United States: U.S. Geological Survey website, https://earthquakes.usgs.gov/hazards/qfaults, accessed 03/25/2019 03:29 PM.

Personius, S.F., compiler, 2002, (5) Fault number 714, Helvetia fault, in Quaternary fault and fold database of the United States: U.S. Geological Survey website, https://earthquakes.usgs.gov/hazards/qfaults, accessed 03/25/2019 03:36 PM.

Personius, S.F., compiler, 2002, (6) Fault number 880, Lacamas Lake fault, in Quaternary fault and fold database of the United States: U.S. Geological Survey website, https://earthquakes.usgs.gov/hazards/qfaults, accessed 03/25/2019 04:08 PM.

Personius, S.F., compiler, 2002, (7) Fault number 717, Newberg fault, in Quaternary fault and fold database of the United States: U.S. Geological Survey website, https://earthquakes.usgs.gov/hazards/qfaults, accessed 03/25/2019 03:55 PM.

Personius, S.F., compiler, 2002, (8) Fault number 875, Oatfield fault, in Quaternary fault and fold database of the United States: U.S. Geological Survey website, https://earthquakes.usgs.gov/hazards/qfaults, accessed 03/25/2019 04:04 PM.

Personius, S.F., and Haller, K.M., compilers, 2017, Fault number 718, Gales Creek fault zone, in Quaternary fault and fold database of the United States: U.S. Geological Survey website, https://earthquakes.usgs.gov/hazards/qfaults, accessed 03/25/2019 03:40 PM. 
Personius, S.F., and Haller, K.M., compilers, 2017, Fault number 877, Portland Hills fault, in Quaternary fault and fold database of the United States: U.S. Geological Survey website, https://earthquakes.usgs.gov/hazards/qfaults, accessed 03/25/2019 04:24 PM.

Personius, S.F., Lidke, D.J., and Haller, K.M., compilers, 2014, Fault number 873, Mount Angel fault, in Quaternary fault and fold database of the United States: U.S. Geological Survey website, https:/earthquakes.usgs.gov/hazards/qfaults, accessed 03/25/2019 03:57 PM.

Petersen, M. D., Cramer, C. H., \& Frankel, A. D. (2002). Simulations of seismic hazard for the Pacific Northwest of the United States from earthquakes associated with the Cascadia subduction zone. In Earthquake Processes: Physical Modelling, Numerical Simulation and Data Analysis Part I (pp. 2147-2168). Birkhäuser, Basel.

Popowski, T.A. (1996) Geology, structure, and tectonic history of the Tualatin Basin, northwestern Oregon, M.S. Thesis, Oregon State University, 126 pp.

Pratt, T.L., J. Odum, W. Stephenson, R. Williams, S. Dadisman, M. Holmes, and B. Haug (2001). Late Pleistocene and Holocene tectonics of the Portland Basin, Oregon and Washington, from high-resolution seismic profiling, Bull. Seismol. Soc. Am. 91 no. 4, 637-650.

Raghunandan, M., Liel, A. B., \& Luco, N. (2015). Collapse risk of buildings in the Pacific northwest region due to subduction earthquakes. Earthquake Spectra, 31(4), 2087-2115.

Redwine, J., R.E. Klinger, L.A. Piety, R.E. Wells, B.L. Sherrod, J.C. Howe, R. Levinston, K. Hornsby, and A. Niem, (2017). Quaternary Activity on the Gales Creek Fault, Northwest Oregon, Geological Society of America Abstracts with Programs. 49, no. 6, 281-7, doi: 10.1130/abs/2017AM-306019.

Reimer, P.J., E. Bard, A. Bayliss, J.W. Beck, P.G. Blackwell, C.B. Ramsey, C.E. Buck, H. Cheng, R.L. Edwards, M. Friedrich, and P.M. Grootes, (2013). IntCal13 and Marine13 radiocarbon age calibration curves $0-50,000$ years cal BP, Radiocarbon, 55 no. 4, 1869-1887.

Schlicker, H.G., and C.T. Finlayson (1979). Geology and geologic hazards of northwestern Clackamas County, Oregon: State of Oregon, Department of Geology and Mineral Industries Bulletin 99, 79 p., 10 pls., scale 1:24,000. 
Schlicker, H.G., R.J. Deacon, and N.H. Twelker (1964). Earthquake geology of the Portland area, Oregon, The ORE BIN, 26, no. 12, 209-230.

Stuiver, M. and H.A. Polach (1977). Discussion reporting of 14 C data. Radiocarbon, 19 no. $3,355-363$.

Tesfamariam, S., \& Wang, Y. (2011). Risk-based seismic retrofit prioritization of reinforced concrete civic infrastructure: case study for State of Oregon schools and emergency facilities. Natural Hazards Review, 13 no. 3, 188-195.

Thomas, G.C., R.S. Crosson, D.L. Carver, T.S. and Yelin (1996). The 25 March 1993 Scotts Mills, Oregon, earthquake and aftershock sequence: Spatial distribution, focal mechanisms, and the Mount Angel fault, Bull. Seismol. Soc. Am. 86, no. 4, 925-935.

University of Washington (1963): Pacific Northwest Seismic Network. International Federation of Digital Seismograph Networks. Dataset/Seismic Network. $10.7914 / \mathrm{SN} / \mathrm{UW}$

Unruh, J.R., Wong, I.G., Bott, J.D.J., Silva, W.J., and Lettis, W.R. (1994) Seismotectonic evaluation, Scoggins Dam, Tualatin Project, northwestern Oregon: Final Report prepared for U.S. Department of the Interior, Bureau of Reclamation. 206 p.4 pls., scale 1:500,000.

U.S. Geological Survey, 2006, Quaternary fault and fold database for the United States, accessed DATE, from USGS web site: http//earthquake.usgs.gov/hazards/qfaults/.

Walsh, K.P., Peterson, G.L., Beeson, M.H., Wells, R.E., Fleck, R.J., Evarts, R.C., Duvall, A., Blakely, R.J., and Burns, S. (2011). A tunnel runs through it--An inside view of the Tualatin Mountains, Oregon: U.S. Geological Survey Scientific Investigations Map 3144.

Wang, Z., and I.P. Madin (2001). Mount Angel fault characteristics using SH-wave refraction and reflection methods: Technical report to United States Geologic Survey (NEHRP).

Weaver, C. S., \& Smith, S. W. (1983). Regional tectonic and earthquake hazard implications of a crustal fault zone in southwestern Washington. Journal of Geophysical Research: Solid Earth, 88 no. B12. 10371-10383. 
Wells, D.L. and K.J. Coppersmith (1994). New Empirical Relationships Among Magnitude, Rupture Length, Rupture Width, Rupture Area, and Surface Displacement: Bull. Seismol. Soc. Am. 84, no. 4, 974-1002.

Wells, R. E., R.J. Blakely, D.K. McPhee, and V.E. Langenheim (2009). The Gales Creek fault accommodates large dextral offset in the Oregon forearc, Geological Society of America Abstracts with Programs, 41, no. 7, 702.

Wells, R.E., Haugerud, R., Niem, A., Niem, W., Ma, L., Madin, I., and Evarts, R., 2018, New geologic mapping of the northwestern Willamette Valley, Oregon, and its American Viticultural Areas (AVAs) - A foundation for understanding their terroir: U.S. Geological Survey Open-File Report 2018-1044, https://doi.org/ $10.3133 /$ ofr20181044

Wells, Ray E., Haugerud, R.A., Niem, A., Niem, W., Ma, L., Evarts, R., Madin, I., Sherrod, D., O'Connor, J., Tolan, T. Beeson, M., Wheeler, K., Sawlan, M., and Hanson, W., in press, Geologic Map of the greater Portland Metropolitan area and surrounding regions, Oregon and Washington, USGS Scientific Investigations Map, scale $1: 63,360$.

Wells, R.E., and R. McCaffrey (2013). Steady rotation of the Cascade arc, Geology, 41 no. 9, 1027-1030, doi: https://doi.org/10.1130/G34514.1.

Wells, R.E. and R.W. Simpson (2001). Northward migration of the Cascadia forearc in the northwestern US and implications for subduction deformation, Earth Planets Space, 53 no. 4, 275-283, doi: https://doi.org/10.1186/BF03352384.

Wells, R.E., C.S. Weaver, and R.J. Blakely (1998). Fore-arc migration in Cascadia and its neotectonic significance, Geology, 26 no. 8, 759-762, doi: https://doi.org/10.1130/0091-7613(1998)026<0759:FAMICA>2.3.CO;2.

Werner, K.S. (1990). I. Direction of maximum horizontal compression in western Oregon determined by borehole breakouts II. Structure and tectonics of the northern Willamette Valley, Oregon, M.S. Thesis, Oregon State University, 159 pp.

Werner, K., J. Nabelek, R. Yeats, and S. Malone (1992). The Mount Angel faultImplications of seismic-reflection data and the Woodburn, Oregon, earthquake sequence of August 1990: Oregon Geology, 54, no. 5, 112-117. 
Wong, I.G., M.A. Hemphill-Haley, L.M. Liberty, and I.P. Madin (2001). The Portland Hills fault: an earthquake generator or just another old fault: Oregon Geology, 63 no. $2,39-50$.

Wong, I., W. Silva, J. Bott, D. Wright, P. Thomas, N. Gregor, S. Li, M. Mabey, A. Sojourner, and Y. Wang (2000). Earthquake scenario and probabilistic ground shaking maps for the Portland, Oregon, metropolitan area: Oregon Department of Geology and Mineral Industries Interpretive Map Series 16, p. 11 maps, 1 CD.

Yeats, R.S., E.P. Graven, K.S. Werner, C. Goldfinger, and T.A. Popowski (1996). Tectonics of the Willamette Valley, Oregon, U.S. Geological Survey Professional Paper 1560, 1, 183-222.

Yelin, T. S. (1992). An earthquake swarm in the north Portland (Oregon) Hills: more speculations on the seismotectonics of the Portland Basin, Geological Society of America Abstracts with Programs, 24, no. 5, 92.

Yelin, T. S., and H.J. Patton (1991). Seismotectonics of the Portland, Oregon, region: Bull. Seismol. Soc. Am., 81 no. 1, 109-130. 
Appendix A. Portland Metropolitan Fault Database

\begin{tabular}{|c|c|c|c|}
\hline \multicolumn{4}{|c|}{ Beaverton Fault } \\
\hline & Data & Type of Data & References \\
\hline \multirow[t]{2}{*}{ Location } & $\begin{array}{l}\text { Fault extends at least } 7 \mathrm{~km} \text { north of the } \\
\text { Farmington Hills }\end{array}$ & $\begin{array}{l}\text { Well water logs } \\
\text { correlating with a } \\
\text { magnetic boundary }\end{array}$ & $\begin{array}{l}\text { Popowski, } \\
1996\end{array}$ \\
\hline & $\begin{array}{l}\text { Fault continues }>3 \mathrm{~km} \text { east of Cooper } \\
\text { Mountain, with down to the north }\end{array}$ & Water well data & $\begin{array}{l}\text { Madin, } \\
1990\end{array}$ \\
\hline Length & $15 \mathrm{~km}$ & QFFD & $\begin{array}{l}\text { Personius, } \\
2002 \mathrm{a}\end{array}$ \\
\hline \multirow[t]{2}{*}{ Strike } & East-West & Aeromagnetics & $\begin{array}{l}\text { Blakely et } \\
\text { al., } 2000\end{array}$ \\
\hline & $\mathrm{N} 86^{\circ} \mathrm{E}$ & QFFD & $\begin{array}{l}\text { Personius, } \\
2002 \mathrm{a}\end{array}$ \\
\hline \multirow[t]{4}{*}{ Dip } & North-verging & $\begin{array}{l}\text { Inversion of gravity } \\
\text { data }\end{array}$ & $\begin{array}{l}\text { McPhee et } \\
\text { al., } 2014\end{array}$ \\
\hline & South & Regional stress field & $\begin{array}{l}\text { Blakely et } \\
\text { al., } 2000 ; \\
\text { McPhee et } \\
\text { al., 2014; } \\
\text { Wells and } \\
\text { McCaffrey, } \\
2013\end{array}$ \\
\hline & $70^{\circ}$ South & $\begin{array}{l}\text { Focal Mechanisms } \\
\text { from microseismicity }\end{array}$ & $\begin{array}{l}\text { University } \\
\text { of } \\
\text { Washington, } \\
1963\end{array}$ \\
\hline & Down to the north & Water wells & $\begin{array}{l}\text { Madin, } \\
1990\end{array}$ \\
\hline \multirow[t]{2}{*}{$\begin{array}{l}\text { Sense of } \\
\text { Movement }\end{array}$} & $\begin{array}{l}\text { Thrust/reverse, responding to north-south } \\
\text { maximum horizontal compressive stress of } \\
\text { the region }\end{array}$ & $\begin{array}{l}\text { Inversion of gravity } \\
\text { data }\end{array}$ & $\begin{array}{l}\text { McPhee et } \\
\text { al., } 2014\end{array}$ \\
\hline & $\begin{array}{l}\text { The Beaverton fault and other contractional } \\
\text { structures in the region such as the Cooper } \\
\text { Mountain anticline and Parrett Mountain } \\
\text { uplift are interpreted to be a left } \\
\text { compressional step between the right-lateral } \\
\text { Canby-Molalla fault and the Gales Creek } \\
\text { fault zone. }\end{array}$ & Aeromagnetic data & $\begin{array}{l}\text { Blakely et } \\
\text { al., } 2000\end{array}$ \\
\hline Slip Rate & $<0.2 \mathrm{~mm} / \mathrm{yr}$ & QFFD & $\begin{array}{l}\text { Personius, } \\
2002 \mathrm{a}\end{array}$ \\
\hline \multirow[t]{3}{*}{ Displacement } & Top of CRBG offset & Water well logs & $\begin{array}{l}\text { Madin, } \\
1990 \\
\end{array}$ \\
\hline & CRBG offset $\sim 350 \mathrm{~m}$ down to the north & Seismic reflection data & $\begin{array}{l}\text { Popowski, } \\
1996\end{array}$ \\
\hline & Fault offsets Eocene basement $>1 \mathrm{~km}$ & $\begin{array}{l}\text { Inversion of gravity } \\
\text { data }\end{array}$ & $\begin{array}{l}\text { McPhee et } \\
\text { al., } 2014\end{array}$ \\
\hline Age & $\begin{array}{l}\text { Late Miocene to Pleistocene. Water well } \\
\text { goes into } 292 \mathrm{~m} \text { of Grande Ronde basalt, } \\
\text { indicative of a topographic low in early to } \\
\text { middle Miocene. }\end{array}$ & Cooper Mountain well & $\begin{array}{l}\text { Popowski, } \\
1996\end{array}$ \\
\hline
\end{tabular}




\begin{tabular}{|l|l|l|l|}
\hline & $\begin{array}{l}\text { Fault growth likely occurred during } \\
\text { deposition of lower Miocene to Pliocene } \\
\text { sediments, suggested by the lower portion of } \\
\text { sedimentary sequence being thickened } \\
\text { closest to the fault. }\end{array}$ & Seismic reflection data & $\begin{array}{l}\text { Popowski, } \\
1996\end{array}$ \\
\hline Other & $\begin{array}{l}\text { Beaverton fault offsets Eocene Basement, } \\
\text { displacing it }>1 \text { km down to the north; and } \\
\text { also displaces the overlying CRBG by } \sim 200 \\
\text { m. }\end{array}$ & $\begin{array}{l}\text { 3D gravity inversion } \\
\text { of the Tualatin Basin }\end{array}$ & $\begin{array}{l}\text { McPhee et } \\
\text { al., 2014 }\end{array}$ \\
\hline
\end{tabular}




\begin{tabular}{|l|l|l|l|}
\hline \multicolumn{4}{|c|}{ Bolton Fault } \\
\hline Location & $\begin{array}{l}\text { Exposed south of Lake } \\
\text { Oswego }\end{array}$ & $\begin{array}{l}\text { Low-altitude } \\
\text { aeromagnetic data }\end{array}$ & Blakely et al., 1995 \\
\hline Length & $9 \mathrm{~km}$ & $\begin{array}{l}\text { Earthquake scenario and } \\
\text { probabilistic ground } \\
\text { shaking maps }\end{array}$ & Wong et al., 2000 \\
\hline Strike & Northwest & Aeromagnetic data & Blakely et al., 1995 \\
\hline Dip & N53 ${ }^{\circ} \mathrm{W}$ & QFFD & Personius, 2002b \\
\hline Slip Rate & $<0.2 \mathrm{~mm} / \mathrm{yr}$ & $\begin{array}{l}\text { Earthquake scenario and } \\
\text { probabilistic ground } \\
\text { shaking maps }\end{array}$ & Wong et al., 2000 \\
\hline $\begin{array}{l}\text { Sense of } \\
\text { Movement }\end{array}$ & Reverse, right lateral & Geologic mapping & Beeson et al., 1989 \\
\hline
\end{tabular}




\begin{tabular}{|c|c|c|c|}
\hline \multicolumn{4}{|c|}{ Canby-Molalla Fault } \\
\hline & Data & Type of Data & References \\
\hline \multirow[t]{2}{*}{ Length } & $51 \mathrm{~km}$ & $\begin{array}{l}\text { Earthquake scenario and } \\
\text { probabilistic ground } \\
\text { shaking maps }\end{array}$ & Wong et al., 2000 \\
\hline & $50 \mathrm{~km}$ & QFFD & Personius, $2002 \mathrm{c}$ \\
\hline Strike & $\mathrm{N} 34^{\circ} \mathrm{W}$ & QFFD & Personius, 2002c \\
\hline \multirow[t]{3}{*}{ Dip } & $70^{\circ}$ Northeast & $\begin{array}{l}\text { Earthquake scenario and } \\
\text { probabilistic ground } \\
\text { shaking maps }\end{array}$ & Wong et al., 2000 \\
\hline & $67^{\circ}$ Northeast & $\begin{array}{l}\text { Focal Mechanisms from } \\
\text { microseismicity }\end{array}$ & $\begin{array}{l}\text { University of } \\
\text { Washington, } 1963\end{array}$ \\
\hline & $75^{\circ}$ Northeast & $\begin{array}{l}\text { Focal Mechanisms from } \\
\text { microseismicity }\end{array}$ & $\begin{array}{l}\text { University of } \\
\text { Washington, } 1963\end{array}$ \\
\hline \multirow[t]{2}{*}{ Slip Rate } & $<0.2 \mathrm{~mm} / \mathrm{yr}$. & QFFD & Personius, 2002c \\
\hline & $\begin{array}{l}\text { Poor geomorphic } \\
\text { expression (based on } \\
\text { offsets from Blakely et al., } \\
\text { 2000) suggests low slip } \\
\text { rates in late Quaternary. }\end{array}$ & QFFD & Personius, 2002c \\
\hline Displacement & $\begin{array}{l}4 \mathrm{~km} \text { right-lateral } \\
\text { separation of underlying } \\
\text { Eocene bedrock, and } \\
\text { minimum of } 150 \mathrm{~m} \text { of } \\
\text { vertical offset in CRBG }\end{array}$ & Aeromagnetic data & Blakely et al., 2000 \\
\hline \multirow{2}{*}{$\begin{array}{l}\text { Sense of } \\
\text { Movement }\end{array}$} & Right-lateral & Aeromagnetic data & Blakely et al., 2000 \\
\hline & Right-lateral, reverse & QFFD & Personius, 2002c \\
\hline
\end{tabular}




\begin{tabular}{|c|c|c|c|}
\hline \multicolumn{4}{|c|}{ East Bank Fault } \\
\hline & Data & Type of Data & Reference \\
\hline Location & $\begin{array}{l}\text { Parallel Portland Hills Fault, } 2-3 \mathrm{~km} \\
\text { to the east. }\end{array}$ & QFFD & Personius, $2002 \mathrm{~d}$ \\
\hline \multirow[t]{2}{*}{ Length } & $29 \mathrm{~km}$ & QFFD & Personius, 2002d \\
\hline & $55 \mathrm{~km}$ & $\begin{array}{l}\text { Earthquake scenario } \\
\text { and probabilistic } \\
\text { ground shaking } \\
\text { maps }\end{array}$ & Wong et al., 2000 \\
\hline \multirow[t]{2}{*}{ Strike } & $\mathrm{N} 46^{\circ} \mathrm{W}$ & QFFD & Personius, $2002 \mathrm{~d}$ \\
\hline & $\mathrm{N} 42^{\circ} \mathrm{W}$ & $\begin{array}{l}\text { Low-altitude } \\
\text { aeromagnetic data }\end{array}$ & Blakely et al., 1995 \\
\hline \multirow[t]{4}{*}{ Dip } & Southwest & QFFD & Personius, $2002 \mathrm{~d}$ \\
\hline & Northeast & $\begin{array}{l}\text { Low-altitude } \\
\text { aeromagnetic data }\end{array}$ & Blakely et al., 1995 \\
\hline & $70-90^{\circ}$ Northeast & $\begin{array}{l}\text { Earthquake scenario } \\
\text { and probabilistic } \\
\text { ground shaking } \\
\text { maps }\end{array}$ & Wong et al., 2000 \\
\hline & $65^{\circ}$ & $\begin{array}{l}\text { Focal Mechanisms } \\
\text { from } \\
\text { microseismicity }\end{array}$ & $\begin{array}{l}\text { University of } \\
\text { Washington, } 1963\end{array}$ \\
\hline \multirow{3}{*}{$\begin{array}{l}\text { Sense of } \\
\text { Movement }\end{array}$} & Reverse & QFFD & Personius, $2002 \mathrm{~d}$ \\
\hline & High angle normal fault & Geologic mapping & $\begin{array}{l}\text { Madin, 1990; Beeson et } \\
\text { al., } 1991\end{array}$ \\
\hline & Reverse slip & $\begin{array}{l}\text { Low-altitude } \\
\text { aeromagnetic data }\end{array}$ & Blakely et al., 1995 \\
\hline \multirow[t]{2}{*}{ Slip Rate } & $<0.2 \mathrm{~mm} / \mathrm{yr}$ & QFFD & Personius, 2002d \\
\hline & Estimated rates $0.05-0.4 \mathrm{~mm} / \mathrm{yr}$ & $\begin{array}{l}\text { Earthquake scenario } \\
\text { and probabilistic } \\
\text { ground shaking } \\
\text { maps }\end{array}$ & Wong et al., 2000 \\
\hline Offset & $\begin{array}{l}60-120 \mathrm{~m} \text { of down to the west } \\
\text { vertical displacement of Miocene } \\
\text { CRBG volcanic rocks and } 60-90 \mathrm{~m} \text { of } \\
\text { vertical displacement of Miocene- } \\
\text { Pliocene Troutdale Formation across } \\
\text { the fault. }\end{array}$ & $\begin{array}{l}\text { Cross-sections and } \\
\text { geologic mapping }\end{array}$ & Beeson et al., 1991 \\
\hline $\begin{array}{l}\text { Most } \\
\text { Recent } \\
\text { Activity }\end{array}$ & $\begin{array}{l}\text { Late Pleistocene or Holocene vertical } \\
\text { displacement, observed in seismic } \\
\text { reflectors. }\end{array}$ & $\begin{array}{l}\text { Shallow seismic } \\
\text { reflection }\end{array}$ & Pratt et al., 2001 \\
\hline
\end{tabular}




\begin{tabular}{|c|c|c|c|}
\hline \multicolumn{4}{|c|}{ Gales Creek Fault } \\
\hline & Data & Type of Data & References \\
\hline \multirow[t]{2}{*}{ Location } & $\begin{array}{l}\text { Fault forms the southwest } \\
\text { margin of the Tualatin Basin }\end{array}$ & Geologic mapping & Popowski, 1996 \\
\hline & Bounding Coast Range uplift & Aeromagnetic data & Blakely et al., 2000 \\
\hline \multirow[t]{2}{*}{ Length } & $31 \mathrm{~km}$ & $\begin{array}{l}\text { Earthquake scenario } \\
\text { and probabilistic } \\
\text { ground shaking } \\
\text { maps }\end{array}$ & Wong et al., 2000 \\
\hline & $73 \mathrm{~km}$ & QFFD & Personius and Haller, 2017a \\
\hline Strike & $\mathrm{N} 41^{\circ} \mathrm{W}$ & QFFD & Personius and Haller, 2017a \\
\hline \multirow[t]{2}{*}{ Dip } & Steeply dipping to the west & $\begin{array}{l}\text { Structural and } \\
\text { geologic mapping }\end{array}$ & Wells terroir map 2018 \\
\hline & $70^{\circ}$ Northeast & $\begin{array}{l}\text { Earthquake scenario } \\
\text { and probabilistic } \\
\text { ground shaking } \\
\text { maps }\end{array}$ & Wong et al., 2000 \\
\hline \multirow{4}{*}{$\begin{array}{l}\text { Sense of } \\
\text { Movement }\end{array}$} & Reverse and right-lateral & QFFD & Personius and Haller, 2017a \\
\hline & Dextral & $\begin{array}{l}\text { Geologic mapping } \\
\text { and gravity data }\end{array}$ & Wells, 2009 \\
\hline & $\begin{array}{l}\text { Dextral strike-slip and vertical } \\
\text { separation apparent along fault } \\
\text { zone }\end{array}$ & $\begin{array}{l}\text { Seismic design } \\
\text { mapping }\end{array}$ & $\begin{array}{l}\text { Geomatrix Consultants Inc., } \\
1995\end{array}$ \\
\hline & $\begin{array}{l}\text { Dextral slip indicated by: } \\
\text { subhorizontal slickensides, } \\
\text { vertical offsets varying along } \\
\text { strike, dextral separation of } \\
\text { Coast Range fold axes, and } 6 \mathrm{~km} \\
\text { dextral separation of CRBG } \\
\text { beds between Dundee Hills and } \\
\text { Parrett Mountain. }\end{array}$ & Aeromagnetic data & Blakely et al., 2000 \\
\hline \multirow[t]{3}{*}{ Slip Rate } & $0.1-0.4 \mathrm{~mm} / \mathrm{yr}$ & $\begin{array}{l}\text { Earthquake scenario } \\
\text { and probabilistic } \\
\text { ground shaking } \\
\text { maps }\end{array}$ & Wong et al., 2000 \\
\hline & $<0.2 \mathrm{~mm} / \mathrm{yr}$ & QFFD & Personius and Haller, 2017a \\
\hline & $\begin{array}{l}0.24 \mathrm{~mm} / \mathrm{yr} \text { since } 50 \mathrm{Ma} \text { and } 0.6 \\
\mathrm{~mm} / \mathrm{yr} \text { since } 15 \mathrm{Ma}\end{array}$ & $\begin{array}{l}\text { Structural and } \\
\text { geologic mapping }\end{array}$ & $\begin{array}{l}\text { Ray Wells, } 1997 \text { (personal } \\
\text { comm. With Wong, 2000) }\end{array}$ \\
\hline Other & $\begin{array}{l}\text { If part of the larger Gales } \\
\text { Creek-Mount Angel fault zone, } \\
\text { the vertical separation may have } \\
\text { reverse sense of displacement }\end{array}$ & $\begin{array}{l}\text { Seismic design } \\
\text { mapping }\end{array}$ & $\begin{array}{l}\text { Geomatrix consultants Inc., } \\
1995\end{array}$ \\
\hline
\end{tabular}




\begin{tabular}{|c|c|c|c|}
\hline \multicolumn{4}{|c|}{ Helvetia Fault } \\
\hline & Data & Type of Data & References \\
\hline Location & $\begin{array}{l}\text { Extends from the McKay } \\
\text { Creek valley SE to Orenco }\end{array}$ & Water well logs & Popowski, 1996 \\
\hline \multirow[t]{2}{*}{ Length } & $10 \mathrm{~km}$ & $\begin{array}{l}\text { Earthquake scenario and } \\
\text { probabilistic ground } \\
\text { shaking maps }\end{array}$ & Wong et al., 2000 \\
\hline & $7 \mathrm{~km}$ & QFFD & Personius, 2002e \\
\hline \multirow[t]{2}{*}{ Strike } & $\mathrm{N} 25^{\circ} \mathrm{W}$ & Water well logs & Popowski, 1996 \\
\hline & $\mathrm{N} 26^{\circ} \mathrm{W}$ & QFFD & Personius, 2002e \\
\hline Dip & $70^{\circ} \mathrm{W}$ & $\begin{array}{l}\text { Earthquake scenario and } \\
\text { probabilistic ground } \\
\text { shaking maps }\end{array}$ & Wong et al., 2000 \\
\hline Slip Rate & $<0.2 \mathrm{~mm} / \mathrm{yr}$ & QFFD & Personius, 2002e \\
\hline $\begin{array}{l}\text { Sense of } \\
\text { Movement }\end{array}$ & Right-lateral, reverse & QFFD & Personius, 2002e \\
\hline Displacement & $\begin{array}{l}100 \mathrm{~m} \text { CRBG is much } \\
\text { thicker to the west }\end{array}$ & Well logs & Popowski, 1996 \\
\hline $\begin{array}{l}\text { Most Recent } \\
\text { Activity }\end{array}$ & $\begin{array}{l}\text { Fault displacement likely } \\
\text { occurred in late Miocene to } \\
\text { Pliocene. }\end{array}$ & $\begin{array}{l}\text { Seismic reflection shows } \\
\text { erosion and folding of } \\
\text { basalt, but no vertical } \\
\text { deformation in overlying } \\
\text { sediments }\end{array}$ & Popowski, 1996 \\
\hline
\end{tabular}




\begin{tabular}{|c|c|c|c|}
\hline \multicolumn{4}{|c|}{ Lackamas Lake (Sandy River/Frontal) fault } \\
\hline & Data & Type of Data & References \\
\hline \multirow[t]{3}{*}{ Location } & $\begin{array}{l}\text { Northern end of Lackamas } \\
\text { Lake }\end{array}$ & $\begin{array}{l}\text { Based on topography and } \\
\text { evidence of fault gouge }\end{array}$ & $\begin{array}{l}\text { Yelin and Patton, } \\
1991\end{array}$ \\
\hline & $\begin{array}{l}\text { Forms northeast boundary } \\
\text { of Portland Basin. }\end{array}$ & Aeromagnetic data & Blakely et al., 1995 \\
\hline & $\begin{array}{l}\text { Parallel Portland Hills } \\
\text { fault, north of the } \\
\text { Columbia River in } \\
\text { Washington }\end{array}$ & $\begin{array}{l}\text { Topography and focal } \\
\text { mechanisms from } \\
\text { microseismicity }\end{array}$ & $\begin{array}{l}\text { Yelin and Patton, } \\
1991\end{array}$ \\
\hline \multirow[t]{2}{*}{ Length } & $\begin{array}{l}7 \mathrm{~km} \text { southeast from } \\
\text { northern end of Lackamas } \\
\text { lake. }\end{array}$ & Topography & $\begin{array}{l}\text { Yelin and Patton, } \\
1991\end{array}$ \\
\hline & $44 \mathrm{~km}$ & $\begin{array}{l}\text { Earthquake scenario and } \\
\text { probabilistic ground shaking } \\
\text { maps }\end{array}$ & Wong et al., 2000 \\
\hline \multirow[t]{3}{*}{ Strike } & Northwest & Topography & $\begin{array}{l}\text { Yelin and Patton, } \\
1991\end{array}$ \\
\hline & $\mathrm{N} 30^{\circ} \mathrm{W}$ & $\begin{array}{l}\text { Zone of earthquakes along } \\
\text { eastern margin of Portland } \\
\text { Basin striking in this } \\
\text { orientation. }\end{array}$ & $\begin{array}{l}\text { Yelin and Patton, } \\
1991\end{array}$ \\
\hline & Northwest & Aeromagnetic data & $\begin{array}{l}\text { Blakely et al., 1995; } \\
2000\end{array}$ \\
\hline \multirow[t]{4}{*}{ Dip } & $\begin{array}{l}\text { Fault is displaced down to } \\
\text { the west }\end{array}$ & $\begin{array}{l}\text { Inference based on } \\
\text { topography }\end{array}$ & Mundorff, 1964 \\
\hline & $70^{\circ}$ Southwest & $\begin{array}{l}\text { Earthquake scenario and } \\
\text { probabilistic ground shaking } \\
\text { maps }\end{array}$ & Wong et al., 2000 \\
\hline & $36^{\circ}$ Southwest & $\begin{array}{l}\text { Focal Mechanisms from } \\
\text { microseismicity }\end{array}$ & $\begin{array}{l}\text { University of } \\
\text { Washington, } 1963\end{array}$ \\
\hline & $45^{\circ}$ Southwest & $\begin{array}{l}\text { Focal Mechanisms from } \\
\text { microseismicity }\end{array}$ & $\begin{array}{l}\text { University of } \\
\text { Washington, } 1963\end{array}$ \\
\hline \multirow[t]{2}{*}{$\begin{array}{l}\text { Sense of } \\
\text { Movement }\end{array}$} & Normal & $\begin{array}{l}\text { Inference based on } \\
\text { topography. }\end{array}$ & Mundorff, 1964 \\
\hline & $\begin{array}{l}\text { Dextral strike-slip with } \\
\text { component of normal } \\
\text { faulting }\end{array}$ & Gravity data & $\begin{array}{l}\text { Yelin and Patton, } \\
1991\end{array}$ \\
\hline Depths & $15-20 \mathrm{~km}$ & $\begin{array}{l}\text { Focal Mechanisms from } \\
\text { earthquakes. }\end{array}$ & $\begin{array}{l}\text { Yelin and Patton, } \\
1991\end{array}$ \\
\hline $\begin{array}{l}\text { Most } \\
\text { Recent } \\
\text { Activity }\end{array}$ & $\begin{array}{l}\text { Mw 5.2 EQ in } 1962 \\
\text { occurred between Frontal } \\
\text { and Portland Hills faults }\end{array}$ & $\begin{array}{l}\text { Location of earthquake } \\
\text { epicenter }\end{array}$ & $\begin{array}{l}\text { Yelin and Patton, } \\
1991\end{array}$ \\
\hline Age & $\begin{array}{l}\text { Age unknown, but fault } \\
\text { displaces rock of late } \\
\text { Oligocene age }\end{array}$ & Groundwater investigation & Mundorff, 1964 \\
\hline Other & $\begin{array}{l}\text { Frontal fault and Portland } \\
\text { Hills fault are right- } \\
\text { stepping, right-lateral fault } \\
\text { zones }\end{array}$ & $\begin{array}{l}\text { Focal Mechanisms from } \\
\text { microseismicity }\end{array}$ & $\begin{array}{l}\text { Yelin and Patton, } \\
1991\end{array}$ \\
\hline
\end{tabular}




\begin{tabular}{|c|c|c|c|}
\hline \multicolumn{4}{|c|}{ Mount Angel Fault } \\
\hline & Data & Type of Data & References \\
\hline \multirow[t]{2}{*}{ Length } & $30 \mathrm{~km}$ & QFFD & Personius, et al., 2014 \\
\hline & $\begin{array}{l}>55 \mathrm{~km} \text {, interpreted to connect } \\
\text { with the geologically mapped } \\
\text { GCF to the northwest. }\end{array}$ & Aeromagnetic data & Blakely et al., 2000 \\
\hline \multirow[t]{4}{*}{ Strike } & $\mathrm{N} 43^{\circ} \mathrm{E}$ & QFFD & Personius, et al., 2014 \\
\hline & $\mathrm{N} 24^{\circ} \mathrm{W}$ & $\begin{array}{l}\text { Earthquake main shock } \\
\text { focal mechanisms }\end{array}$ & $\begin{array}{l}\text { Blakely et al., 2000; } \\
\text { Thomas et al., } 1996\end{array}$ \\
\hline & $\begin{array}{l}\text { Defined plane in West- } \\
\text { Northwest direction }\end{array}$ & $\begin{array}{l}\text { Aftershocks from } 1993 \\
\text { Scotts Mills EQ } \\
\end{array}$ & Yeats et al., 1996 \\
\hline & Northwest & $\begin{array}{l}\text { Earthquake focal } \\
\text { mechanisms (1993 } \\
\text { Scotts Mills EQ) }\end{array}$ & Thomas et al., 1996 \\
\hline \multirow[t]{4}{*}{ Dip } & $60^{\circ}$ Northeast & \begin{tabular}{|l|} 
Earthquake focal \\
mechanisms (1993 \\
Scotts Mills EQ) \\
\end{tabular} & Thomas et al., 1996 \\
\hline & $58^{\circ}$ Northeast & $\begin{array}{l}\text { Earthquake main shock } \\
\text { focal mechanisms }\end{array}$ & $\begin{array}{l}\text { Blakely et al., 2000; } \\
\text { Thomas et al., } 1996\end{array}$ \\
\hline & $60-70^{\circ}$ Northeast & $\begin{array}{l}\text { Seismic reflection and } \\
\text { aeromagnetic data }\end{array}$ & $\begin{array}{l}\text { Werner, 1990; 1992; } \\
\text { Yeats et al., } 1996\end{array}$ \\
\hline & $80^{\circ}$ & $\begin{array}{l}\text { Focal Mechanisms } \\
\text { from microseismicity }\end{array}$ & $\begin{array}{l}\text { University of } \\
\text { Washington, } 1963\end{array}$ \\
\hline \multirow{4}{*}{$\begin{array}{l}\text { Sense of } \\
\text { Movement }\end{array}$} & Reverse, right-lateral & QFFD & Personius, et al., 2014 \\
\hline & $\begin{array}{l}\text { Subequal reverse and right- } \\
\text { lateral strike-slip }\end{array}$ & $\begin{array}{l}\text { Earthquake focal } \\
\text { mechanisms (1993 } \\
\text { Scotts Mills EQ) }\end{array}$ & Thomas et al., 1996 \\
\hline & $\begin{array}{l}\text { Dip-slip and right-lateral strike- } \\
\text { slip }\end{array}$ & Geologically mapped & Beeson et al., 1989 \\
\hline & High angle reverse-oblique & Boreholes & Werner, 1990 \\
\hline \multirow[t]{2}{*}{ Slip Rate } & $<0.2 \mathrm{~mm} / \mathrm{yr}$ & QFFD & Personius, et al., 2014 \\
\hline & $0.23 \mathrm{~mm} / \mathrm{yr}$ (for the past $30 \mathrm{Ka}$ ) & $\begin{array}{l}\text { SH-wave refraction } \\
\text { and reflection methods }\end{array}$ & $\begin{array}{l}\text { Wang and Madin, } \\
2001\end{array}$ \\
\hline Displacement & $200 \mathrm{~m}$ offset in CRBG & \begin{tabular}{|l|} 
Seismic and \\
Aeromagnetic data
\end{tabular} & Liberty et al., 1999 \\
\hline $\begin{array}{l}\text { Most Recent } \\
\text { Activity }\end{array}$ & $\begin{array}{l}\text { Mw 5.6 Scott Mills Earthquake } \\
\text { (1993) }\end{array}$ & $\begin{array}{l}\text { Aeromagnetic data; } \\
\text { Focal mechanisms }\end{array}$ & $\begin{array}{l}\text { Blakely et al., 2000; } \\
\text { Yeats et al., } 1996\end{array}$ \\
\hline Other & $\begin{array}{l}\text { May connect with the Gales } \\
\text { Creek fault } 25 \mathrm{~km} \text { to the } \\
\text { northwest }\end{array}$ & Aeromagnetic data & Blakely et al., 2000 \\
\hline
\end{tabular}




\begin{tabular}{|c|c|c|c|}
\hline \multicolumn{4}{|c|}{ Newberg Fault } \\
\hline & Data & Type of Data & References \\
\hline Location & $\begin{array}{l}\text { Part of Gales Creek- } \\
\text { Mount Angel northwest- } \\
\text { striking structural zone }\end{array}$ & QFFD & Personius, 2002g \\
\hline Length & $8 \mathrm{~km}$ & $\begin{array}{l}\text { Earthquake scenario and } \\
\text { probabilistic ground shaking } \\
\text { maps }\end{array}$ & Wong et al., 2000 \\
\hline & $5 \mathrm{~km}$ & QFFD & \\
\hline Strike & $\mathrm{N} 42^{\circ} \mathrm{W}$ & QFFD & Personius, 2002g \\
\hline Dip & $70^{\circ}$ Southwest & $\begin{array}{l}\text { Earthquake scenario and } \\
\text { probabilistic ground shaking } \\
\text { maps }\end{array}$ & Wong et al., 2000 \\
\hline Slip Rate & $<0.2 \mathrm{~mm} / \mathrm{yr}$ & QFFD & Personius, 2002g \\
\hline $\begin{array}{l}\text { Sense of } \\
\text { Movement }\end{array}$ & $\begin{array}{l}\text { Reverse, if connected to } \\
\text { Gales Creek / Mt. Angel } \\
\text { fault zone }\end{array}$ & $\begin{array}{l}\text { Geologic and structural } \\
\text { mapping }\end{array}$ & Wells et al., 2018 \\
\hline Other & $\begin{array}{l}\text { This structure may link } \\
\text { the Mount Angel and } \\
\text { Gales Creek faults }\end{array}$ & Magnetic expression & Blakely et al., 2000 \\
\hline
\end{tabular}




\begin{tabular}{|c|c|c|c|}
\hline \multicolumn{4}{|c|}{ Oatfield (Sylvan-Oatfield) Fault } \\
\hline & Data & Type of Data & Reference \\
\hline Location & $\begin{array}{l}\text { Along western flank of the } \\
\text { Portland Hills. }\end{array}$ & Gravity & $\begin{array}{l}\text { Blakely et al., } \\
2000\end{array}$ \\
\hline \multirow[t]{3}{*}{ Length } & $29 \mathrm{~km}$ & QFFD & $\begin{array}{l}\text { Personius, } \\
2002 \mathrm{~h}\end{array}$ \\
\hline & $40 \mathrm{~km}$ & Gravity & $\begin{array}{l}\text { Blakely et al., } \\
2000\end{array}$ \\
\hline & $40 \mathrm{~km}$ & $\begin{array}{l}\text { Earthquake scenario and } \\
\text { probabilistic ground shaking } \\
\text { maps }\end{array}$ & $\begin{array}{l}\text { Wong et al., } \\
2000\end{array}$ \\
\hline Strike & $\mathrm{N} 41^{\circ} \mathrm{W}$ & QFFD & $\begin{array}{l}\text { Personius, } \\
2002 \mathrm{~h}\end{array}$ \\
\hline \multirow[t]{5}{*}{ Dip } & Northeast & QFFD & $\begin{array}{l}\text { Personius, } \\
2002 \mathrm{~h}\end{array}$ \\
\hline & $70^{\circ}$ East & $\begin{array}{l}\text { Earthquake scenario and } \\
\text { probabilistic ground shaking } \\
\text { maps }\end{array}$ & $\begin{array}{l}\text { Wong et al., } \\
2000\end{array}$ \\
\hline & Southwest & Geologically mapped & $\begin{array}{l}\text { Beeson et al., } \\
1989\end{array}$ \\
\hline & East-dipping & $\begin{array}{l}\text { Exposures from boreholes } \\
\text { drilled for metropolitan light- } \\
\text { rail tunnel through the Portland } \\
\text { Hills. }\end{array}$ & $\begin{array}{l}\text { Blakely et al., } \\
1997\end{array}$ \\
\hline & Steeply; Northeast & Aeromagnetic data & $\begin{array}{l}\text { Blakely et al., } \\
1995\end{array}$ \\
\hline Displacement & $\begin{array}{l}\text { West Sylvan Fault: } 7-20 \mathrm{~m} \\
\text { Central Sylvan Fault: } 76-100 \mathrm{~m}\end{array}$ & $\begin{array}{l}\text { Excavation across Tualatin } \\
\text { Mountains for construction of } \\
\text { light-rail tunnel }\end{array}$ & $\begin{array}{l}\text { Walsh et al., } \\
2011\end{array}$ \\
\hline \multirow[t]{5}{*}{$\begin{array}{l}\text { Sense of } \\
\text { Movement }\end{array}$} & Reverse and right-lateral & QFFD & $\begin{array}{l}\text { Personius, } \\
2002 \mathrm{~h}\end{array}$ \\
\hline & High-angle reverse fault & Geologically mapped & $\begin{array}{l}\text { Beeson et al., } \\
1989\end{array}$ \\
\hline & Reverse and strike slip & Microseismicity & Yelin, 1992 \\
\hline & Thrust & Aeromagnetic data & $\begin{array}{l}\text { Blakely et al., } \\
1995\end{array}$ \\
\hline & Reverse (vertical) and dextral & $\begin{array}{l}\text { Exposures from boreholes } \\
\text { drilled for metropolitan light- } \\
\text { rail tunnel through the Portland } \\
\text { Hills. }\end{array}$ & $\begin{array}{l}\text { Blakely et al., } \\
1997\end{array}$ \\
\hline \multirow[t]{2}{*}{ Slip Rate } & $<0.2 \mathrm{~mm} / \mathrm{yr}$ & QFFD & $\begin{array}{l}\text { Personius, } \\
2002 \mathrm{~h}\end{array}$ \\
\hline & Estimate of $0.05-0.4 \mathrm{~mm} / \mathrm{yr}$ & $\begin{array}{l}\text { Earthquake scenario and } \\
\text { probabilistic ground shaking } \\
\text { maps }\end{array}$ & $\begin{array}{l}\text { Wong et al., } \\
2000\end{array}$ \\
\hline (vertical) & $\begin{array}{l}\text { West Sylvan Fault: 0.01-0.02 } \\
\text { mm/yr. } \\
\text { Central Sylvan Fault: } 0.07-0.08 \\
\mathrm{~mm} / \mathrm{yr} \text {. }\end{array}$ & $\begin{array}{l}\text { Excavation across Tualatin } \\
\text { Mountains for construction of } \\
\text { light-rail tunnel }\end{array}$ & $\begin{array}{l}\text { Walsh et al., } \\
2011\end{array}$ \\
\hline Offset & $\begin{array}{l}100 \mathrm{~m} \text { offset of } 1 \mathrm{Ma} \text { Boring } \\
\text { Lava }\end{array}$ & $\begin{array}{l}\text { Exposures from boreholes } \\
\text { drilled for metropolitan light- }\end{array}$ & $\begin{array}{l}\text { Blakely et al., } \\
1997\end{array}$ \\
\hline
\end{tabular}




\begin{tabular}{|c|c|c|c|}
\hline & & $\begin{array}{l}\text { rail tunnel through the Portland } \\
\text { Hills. }\end{array}$ & \\
\hline \multirow[t]{4}{*}{ Other } & $\begin{array}{l}\text { The fault forms linear magnetic } \\
\text { anomalies and southwest-facing } \\
\text { escarpments in volcanic rocks of } \\
\text { the Miocene CRBG in Tualatin } \\
\text { Mtns, and northern Willamette } \\
\text { Valley. }\end{array}$ & Geologically mapped & $\begin{array}{l}\text { Beeson et al., } \\
\text { 1989; } 1991\end{array}$ \\
\hline & $\begin{array}{l}150 \mathrm{~m} \text { of Mio-Pleistocene age } \\
\text { sediments are stratigraphically } \\
\text { above CRBG }\end{array}$ & Water wells & $\begin{array}{l}\text { Popowski, } \\
1996 ; \text { Madin, } \\
1990\end{array}$ \\
\hline & $\begin{array}{l}\text { Boring lava vents along the } \\
\text { length of the fault suggest it acted } \\
\text { as a conduit for emplacement of } \\
\text { Boring lava }\end{array}$ & $\begin{array}{l}\text { Water wells and geologically } \\
\text { mapping }\end{array}$ & $\begin{array}{l}\text { Popowski, } \\
1996\end{array}$ \\
\hline & $\begin{array}{l}\text { The Sylvan fault is interpreted as } \\
\text { a subsurface continuation of the } \\
\text { Oatfield fault. }\end{array}$ & Gravity data & $\begin{array}{l}\text { Blakely et al., } \\
2000\end{array}$ \\
\hline
\end{tabular}




\begin{tabular}{|c|c|c|c|}
\hline \multicolumn{4}{|c|}{ Portland Hills Fault } \\
\hline & Data & Type of Data & References \\
\hline \multirow[t]{2}{*}{ Location } & $\begin{array}{l}\text { Part of Portland Hills-Clackamas } \\
\text { River structural zone, SE Portland? }\end{array}$ & $\begin{array}{l}\text { Geochemical analysis of } \\
\text { Frenchman Springs } \\
\text { Member of the CRBG }\end{array}$ & $\begin{array}{l}\text { Beeson et al., } \\
1985\end{array}$ \\
\hline & $\begin{array}{l}\text { Forms NE margin of Tualatin } \\
\text { Mountains and SW margin of } \\
\text { Portland Basin }\end{array}$ & QFFD & $\begin{array}{l}\text { Personius and } \\
\text { Haller, 2017b }\end{array}$ \\
\hline \multirow[t]{3}{*}{ Length } & $49 \mathrm{~km}$ & QFFD & $\begin{array}{l}\text { Personius and } \\
\text { Haller, 2017b }\end{array}$ \\
\hline & $\begin{array}{l}\text { Active zone of deformation is } 400 \mathrm{~m} \\
\text { wide }\end{array}$ & $\begin{array}{l}\text { Seismic reflection, GPR, } \\
\text { magnetic methods, } \\
\text { trench excavation@ } \\
\text { North Clackamas Park } \\
\text { and Rowe Middle school }\end{array}$ & $\begin{array}{l}\text { Liberty et al., } \\
2003\end{array}$ \\
\hline & $62 \mathrm{~km}$ & $\begin{array}{l}\text { Earthquake scenario and } \\
\text { probabilistic ground } \\
\text { shaking maps }\end{array}$ & Wong et al., 2000 \\
\hline \multirow[t]{2}{*}{ Strike } & $\mathrm{N} 37^{\circ} \mathrm{W}$ & QFFD & $\begin{array}{l}\text { Personius and } \\
\text { Haller, 2017b }\end{array}$ \\
\hline & Northwest & Geologically mapped & $\begin{array}{l}\text { Beeson et al., } \\
1989\end{array}$ \\
\hline \multirow[t]{8}{*}{ Dip } & Southwest & QFFD & $\begin{array}{l}\text { Personius and } \\
\text { Haller, 2017b } \\
\end{array}$ \\
\hline & Steeply Southwest & Geologic Mapping & $\begin{array}{l}\text { Schlicker and } \\
\text { Finlayson, } 1979\end{array}$ \\
\hline & Southwest & $\begin{array}{l}\text { Aerial and field } \\
\text { reconnaissance }\end{array}$ & Unruh et al, 1994 \\
\hline & Northeast & Geologic mapping & $\begin{array}{l}\text { Beeson et al., } \\
1989\end{array}$ \\
\hline & $70^{\circ}$ Northeast & Seismic design mapping & $\begin{array}{l}\text { Geomatrix } \\
\text { Consultants, Inc., } \\
1995\end{array}$ \\
\hline & Northeast side up displacement & $\begin{array}{l}\text { Shallow seismic } \\
\text { reflection data }\end{array}$ & Pratt et al., 2001 \\
\hline & Southwest & Aeromagnetic data & $\begin{array}{l}\text { Blakely et al., } \\
1995\end{array}$ \\
\hline & $70-90^{\circ}$ Southwest & $\begin{array}{l}\text { Earthquake scenario and } \\
\text { probabilistic ground } \\
\text { shaking maps }\end{array}$ & Wong et al., 2000 \\
\hline \multirow[t]{5}{*}{$\begin{array}{l}\text { Sense of } \\
\text { Movement }\end{array}$} & Reverse, right-lateral & QFFD & $\begin{array}{l}\text { Personius and } \\
\text { Haller, 2017b }\end{array}$ \\
\hline & Right-lateral & Geologic mapping & $\begin{array}{l}\text { Schlicker and } \\
\text { Finlayson, } 1979\end{array}$ \\
\hline & Right-lateral strike slip & Geologic mapping & $\begin{array}{l}\text { Beeson et al., } \\
1985\end{array}$ \\
\hline & Reverse to vertical & $\begin{array}{l}\text { Earthquake scenario and } \\
\text { probabilistic ground } \\
\text { shaking maps }\end{array}$ & Wong et al., 2000 \\
\hline & Normal & $\begin{array}{l}\text { Geologic mapping, based } \\
\text { on CRBG and November } \\
1962 \text { earthquake }\end{array}$ & $\begin{array}{l}\text { Schlicker et al., } \\
\text { 1964; Balsille and } \\
\text { Benson, } 1971\end{array}$ \\
\hline
\end{tabular}




\begin{tabular}{|c|c|c|c|}
\hline & Right-oblique strike-slip & Geologic mapping & $\begin{array}{l}\text { Beeson et al., } \\
1989\end{array}$ \\
\hline & $\begin{array}{l}\text { Asymmetrical folding above SW } \\
\text { dipping blind thrust }\end{array}$ & $\begin{array}{l}\text { Based on topography of } \\
\text { Portland Hills } \\
\text { escarpment }\end{array}$ & Unruh et al., 1994 \\
\hline & Near vertical dip slip & Geologic mapping & $\begin{array}{l}\text { Beeson et al., } \\
1989\end{array}$ \\
\hline & Reverse or reverse oblique & Seismic design mapping & $\begin{array}{l}\text { Geomatrix } \\
\text { consultants, Inc., } \\
1995\end{array}$ \\
\hline & Transpressional & Aeromagnetic data & $\begin{array}{l}\text { Blakely et al., } \\
1995\end{array}$ \\
\hline & $\begin{array}{l}\text { Strike-slip with minor dip slip } \\
\text { component. }\end{array}$ & $\begin{array}{l}\text { Seismic reflection, GPR, } \\
\text { magnetic methods, } \\
\text { trench excavation at } \\
\text { North Clackamas Park } \\
\text { and Rowe Middle school, } \\
\text { Clackamas. }\end{array}$ & Liberty et al, 2003 \\
\hline & Strike-slip or dip slip & Seismic profiling & Pratt et al., 2001 \\
\hline & $\begin{array}{l}\text { Reverse is primary mode of } \\
\text { deformation. }\end{array}$ & Seismic reflection data & Wong et al., 2001 \\
\hline & $\begin{array}{l}\text { Right-stepping, right-lateral fault } \\
\text { zone. }\end{array}$ & Microseismicity & $\begin{array}{l}\text { Yelin and Patton, } \\
1991\end{array}$ \\
\hline & $\begin{array}{l}\text { Reverse displacement, with } \\
\text { component of right-lateral strike slip. }\end{array}$ & $\begin{array}{l}\text { Tectonic setting and } \\
\text { geologic mapping }\end{array}$ & $\begin{array}{l}\text { Beeson et al., } \\
\text { 1989; Blakely et } \\
\text { al., } 2000\end{array}$ \\
\hline & Reverse & Aeromagnetic data & $\begin{array}{l}\text { Blakely et al., } \\
1995\end{array}$ \\
\hline Slip Rate & $<0.2 \mathrm{~mm} / \mathrm{yr}$ & QFFD & $\begin{array}{l}\text { Personius and } \\
\text { Haller, } 2017 \mathrm{~b}\end{array}$ \\
\hline Depth & $5-20 \mathrm{~km}$ & Microseismicity & $\begin{array}{l}\text { Wong et al., 2001; } \\
\text { Yelin and Patton, } \\
1991\end{array}$ \\
\hline \multirow[t]{3}{*}{ Other } & $\begin{array}{l}\text { Fault defines western margin of pull- } \\
\text { apart basin. }\end{array}$ & Geologic mapping & $\begin{array}{l}\text { Beeson et al., } \\
1989\end{array}$ \\
\hline & Faulted anticline of Miocene CRBG. & $\begin{array}{l}\text { Geologic mapping and } \\
\text { subsurface data }\end{array}$ & Evarts et al., 2009 \\
\hline & $\begin{array}{l}\text { Fault trace corresponds with low } \\
\text { gravity values (-28 mGal), so likely } \\
\text { dense basement rocks are not major } \\
\text { part of Portand Hills uplift. }\end{array}$ & Gravity inversion & $\begin{array}{l}\text { McPhee et al., } \\
2014\end{array}$ \\
\hline
\end{tabular}




\begin{tabular}{|c|c|c|c|}
\hline \multicolumn{4}{|c|}{ Sherwood Fault } \\
\hline & Data & Type of Data & References \\
\hline \multirow[t]{4}{*}{ Location } & $\begin{array}{l}\text { Separates northeast dipping } \\
\text { Chehalem Mountain beds from } \\
\text { SE dipping Parrett Mountains }\end{array}$ & Water well logs & $\begin{array}{l}\text { Hart and Newcomb, } \\
1965\end{array}$ \\
\hline & $\begin{array}{l}\text { Possibly continues along northern } \\
\text { end of Amity Hills. }\end{array}$ & Seismic profiles & Yeats et al., 1996 \\
\hline & $\begin{array}{l}\text { Appears as southwest } \\
\text { continuation of northern margin } \\
\text { of Columbia trans-arc lowland } \\
\text { through which CRBG traversed } \\
\text { the Cascade Range. }\end{array}$ & $\begin{array}{l}\text { Geochemistry and } \\
\text { geologic mapping of } \\
\text { the CRBG }\end{array}$ & Beeson et al., 1989a \\
\hline & $\begin{array}{l}\text { Bounds the southeastern margin } \\
\text { of the Tualatin Basin and northern } \\
\text { margin of the northern Willamette } \\
\text { basin }\end{array}$ & $\begin{array}{l}\text { A broad northeast- } \\
\text { trending gravity high }\end{array}$ & McPhee et al., 2014 \\
\hline Length & $14.5 \mathrm{~km}$ & $\begin{array}{l}\text { Geologic mapping of } \\
\text { bedrock faults. }\end{array}$ & Wells et al., 2019 \\
\hline Strike & Northeast & Aeromagnetic data & Blakely et al., 2000 \\
\hline Dip & $50^{\circ}$ South & $\begin{array}{l}\text { Focal Mechanisms } \\
\text { from microseismicity }\end{array}$ & $\begin{array}{l}\text { University of } \\
\text { Washington, } 1963\end{array}$ \\
\hline Displacement & $\begin{array}{l}\text { Basement to northwest of the } \\
\text { fault is offset vertically } \sim 300 \mathrm{~m} \\
\text { lower than to the south }\end{array}$ & Aeromagnetic data & McPhee et al., 2014 \\
\hline \multirow[t]{2}{*}{ Other } & $\begin{array}{l}\text { Originated as normal fault in the } \\
\text { Eocene. }\end{array}$ & Aeromagnetic data & McPhee et al., 2014 \\
\hline & $\begin{array}{l}\text { On strike and possibly related to } \\
\text { Lake Oswego fault. }\end{array}$ & Geologic mapping & $\begin{array}{l}\text { Popowski, 1996; } \\
\text { Beeson et al., } 1989\end{array}$ \\
\hline
\end{tabular}


Appendix B. Fault data from focal mechanisms (University of Washington, 1963). Distance from fault measured from ArcGIS; Length of fault measured using Pythagorean theorem with depth of earthquake and distance from fault.

\begin{tabular}{|c|c|c|c|c|c|}
\hline \multicolumn{6}{|c|}{ Beaverton Fault } \\
\hline \multicolumn{4}{|c|}{ Focal Mechanism Information } & \multirow[b]{2}{*}{$\begin{array}{c}\text { Distance from } \\
\text { fault }(\mathbf{k m})\end{array}$} & \multirow[b]{2}{*}{$\begin{array}{c}\text { Length of } \\
\text { fault at Depth }\end{array}$} \\
\hline Strike & Dip & $\begin{array}{c}\text { Magnitude } \\
\text { EQ }\end{array}$ & $\begin{array}{l}\text { Depth of } \\
\text { EQ (km) }\end{array}$ & & \\
\hline $60^{\circ}$ & $70^{\circ}$ & 2.6 & 26.1 & 0.659 & 26.1 \\
\hline
\end{tabular}

\begin{tabular}{|c|c|r|r|r|r|}
\hline \multicolumn{7}{|c|}{ Canby Molalla Fault } \\
\hline \multicolumn{7}{|c|}{ Focal Mechanism Information } & & \multicolumn{1}{c|}{$\begin{array}{c}\text { Length of } \\
\text { Strike }\end{array}$} & Dip & $\begin{array}{c}\text { Magnitude } \\
\text { EQ }\end{array}$ & $\begin{array}{c}\text { Depth of } \\
\text { EQ (km) }\end{array}$ & $\begin{array}{c}\text { Distance from } \\
\text { fault (km) }\end{array}$ & $\begin{array}{c}\text { Lenlt at Depth } \\
\text { fauth }\end{array}$ \\
\hline $315^{\circ}$ & $75^{\circ}$ & 2.4 & 21.2 & 4.8 & 21.7 \\
\hline $319^{\circ}$ & $67^{\circ}$ & 2.1 & 22.2 & 3.46 & 22.4 \\
\hline
\end{tabular}

\begin{tabular}{|c|c|c|c|c|c|}
\hline \multicolumn{7}{|c|}{ East Bank Fault } \\
\hline Strike & Dip & $\begin{array}{c}\text { Magnitude } \\
\text { EQ }\end{array}$ & $\begin{array}{c}\text { Depth of } \\
\text { EQ (km) }\end{array}$ & $\begin{array}{c}\text { Distance from } \\
\text { fault (km) }\end{array}$ & $\begin{array}{c}\text { Length of } \\
\text { fault at Depth }\end{array}$ \\
\hline $320^{\circ}$ & $65^{\circ}$ & 2.8 & 15.2 & 0.34 & 15.2 \\
\hline
\end{tabular}

\begin{tabular}{|l|c|r|r|r|r|}
\hline \multicolumn{7}{|c|}{ Lackamas Lake Fault } \\
\hline \multicolumn{7}{|c|}{ Focal Mechanism Information } & & \multicolumn{1}{c|}{} \\
\hline Strike & Dip & $\begin{array}{c}\text { Magnitude } \\
\text { EQ }\end{array}$ & $\begin{array}{c}\text { Depth of } \\
\text { EQ (km) }\end{array}$ & $\begin{array}{c}\text { Distance from } \\
\text { fault (km) }\end{array}$ & $\begin{array}{c}\text { Length of } \\
\text { fault at Depth }\end{array}$ \\
\hline $104^{\circ}$ & $36^{\circ}$ & 2.5 & 5.6 & 4.06 & 6.9 \\
\hline $125^{\circ}$ & $45^{\circ}$ & 2.5 & 15 & 7.13 & 16.6 \\
\hline
\end{tabular}

\begin{tabular}{|l|c|c|c|c|c|}
\hline \multicolumn{7}{|c|}{ Mount Angel Fault } \\
\hline \multicolumn{7}{|c|}{ Focal Mechanism Information } & & \\
\hline Strike & Dip & $\begin{array}{c}\text { Magnitude } \\
\text { EQ }\end{array}$ & $\begin{array}{c}\text { Depth of } \\
\text { EQ (km) }\end{array}$ & $\begin{array}{c}\text { Distance from } \\
\text { fault (km) }\end{array}$ & $\begin{array}{c}\text { Length of } \\
\text { fault at Depth }\end{array}$ \\
\hline $340^{\circ}$ & $80^{\circ}$ & 2.4 & 25.2 & 8.89 & 26.7 \\
\hline
\end{tabular}

\begin{tabular}{|l|c|c|c|c|c|}
\hline \multicolumn{7}{|c|}{ Sherwood Fault } \\
\hline \multicolumn{7}{|c|}{ Focal Mechanism Information } & & \\
\hline Strike & Dip & $\begin{array}{c}\text { Magnitude } \\
\text { EQ }\end{array}$ & $\begin{array}{c}\text { Depth of } \\
\text { EQ (km) }\end{array}$ & $\begin{array}{c}\text { Distance from } \\
\text { fault (km) }\end{array}$ & $\begin{array}{c}\text { Length of } \\
\text { fault at Depth }\end{array}$ \\
\hline $95^{\circ}$ & $50^{\circ}$ & 2 & 20.7 & 2.77 & 20.9 \\
\hline
\end{tabular}




\begin{tabular}{|c|c|c|c|c|c|c|}
\hline & $\stackrel{\vec{B}}{\mathbf{g}}$ & \& & 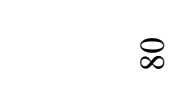 & $\stackrel{\text { \& }}{\text { f }}$ & ஜ) & 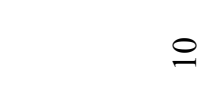 \\
\hline & 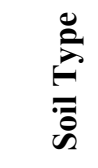 & 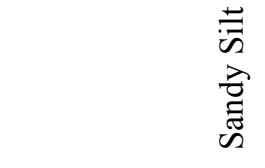 & 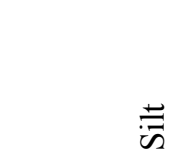 & $\overline{\tilde{\omega}}$ & $\begin{array}{l}\vec{\Xi} \\
\vec{U} \\
\vec{\Xi} \\
\vec{n}\end{array}$ & $\overline{\bar{n}}$ \\
\hline & 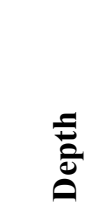 & 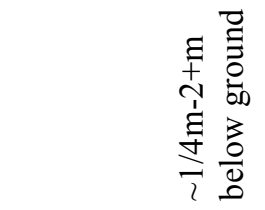 & 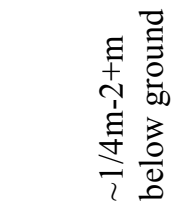 & 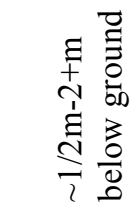 & 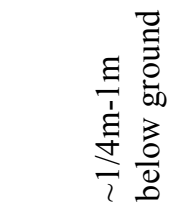 & 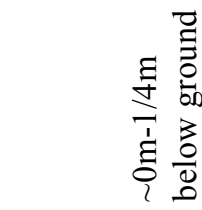 \\
\hline & $\frac{\bar{\theta}}{0}$ & 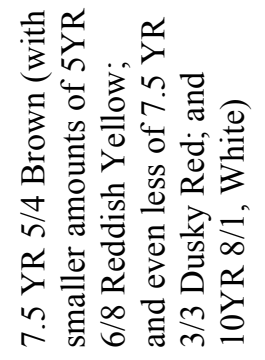 & 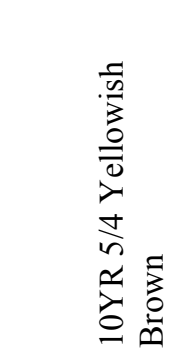 & 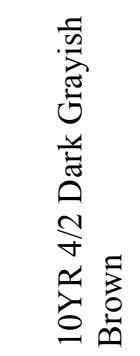 & 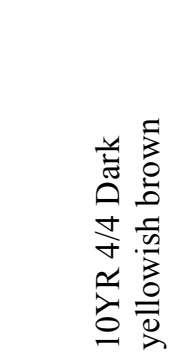 & 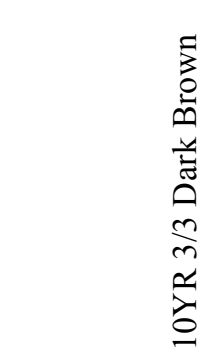 \\
\hline$\stackrel{0}{0}$ & 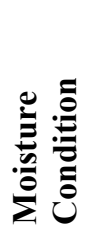 & $\vec{A}$ & 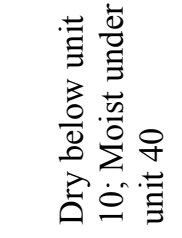 & 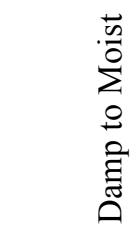 & 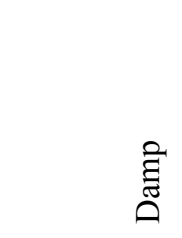 & $\vec{b}$ \\
\hline 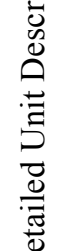 & 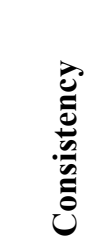 & 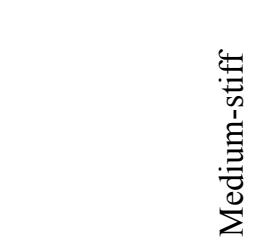 & 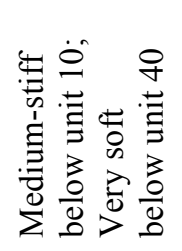 & 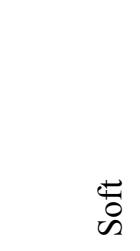 & 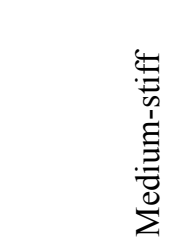 & 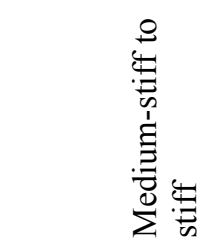 \\
\hline 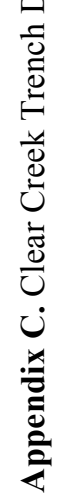 & 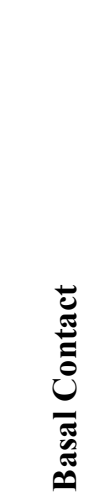 & 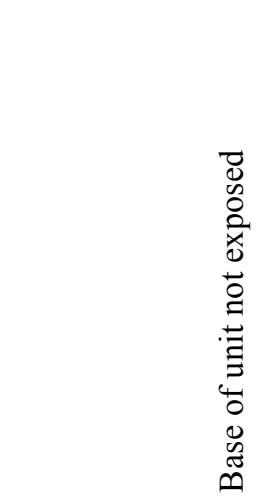 & 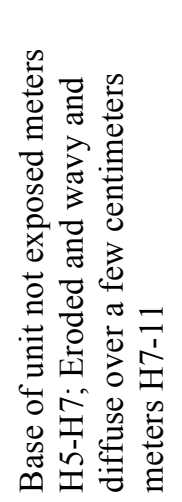 & 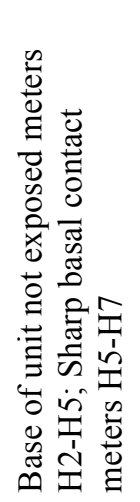 & 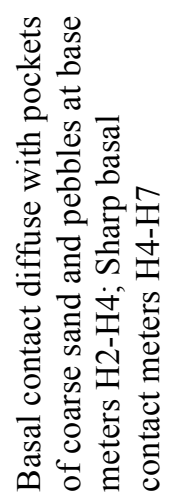 & 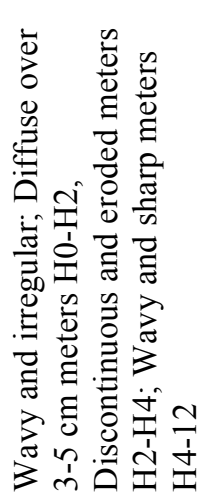 \\
\hline
\end{tabular}




\begin{tabular}{|c|c|c|c|c|c|c|}
\hline & 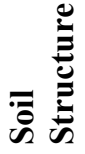 & 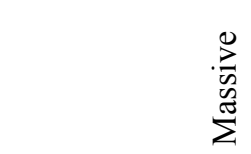 & 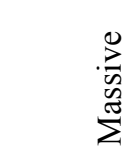 & 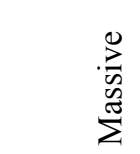 & 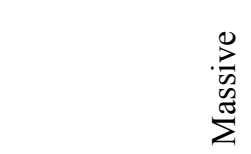 & 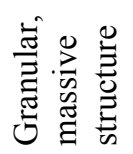 \\
\hline & : & \& & $\triangleright$ & q & pి & $\stackrel{\varrho}{ }$ \\
\hline & 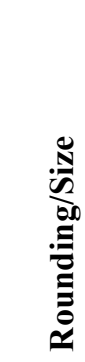 & 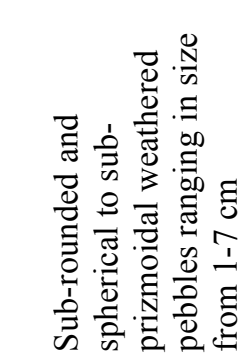 & 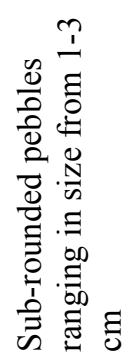 & 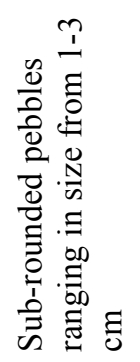 & 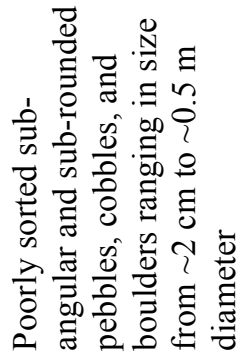 & $\underset{z}{\varangle}$ \\
\hline & 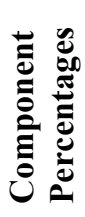 & 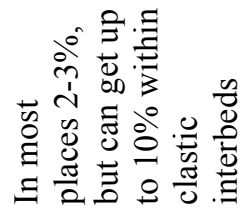 & $\frac{\partial}{\vec{v}}$ & $\frac{\partial}{\vec{v}}$ & $\begin{array}{l}\stackrel{0}{0} \\
\text { ஸे } \\
\text { ñ }\end{array}$ & $\underset{z}{\varangle}$ \\
\hline & 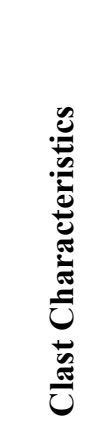 & 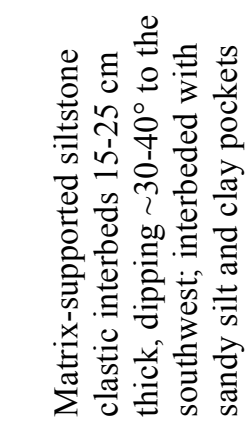 & 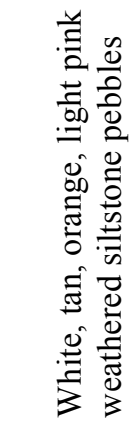 & 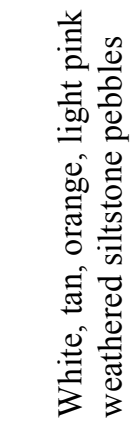 & 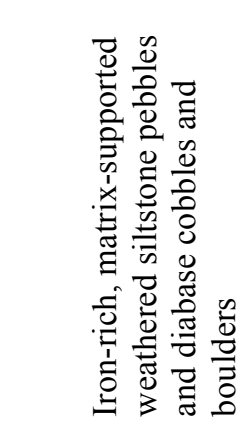 & $\underset{Z}{\varangle}$ \\
\hline 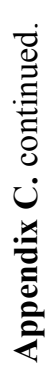 & $\stackrel{\bar{\Xi}}{\overline{0}}$ & 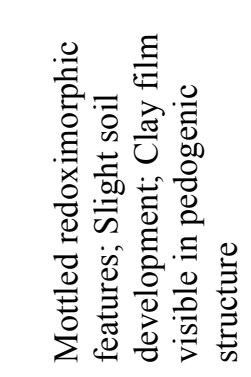 & 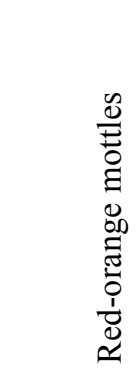 & 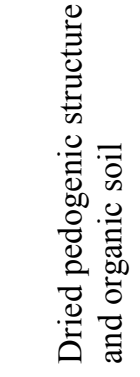 & & 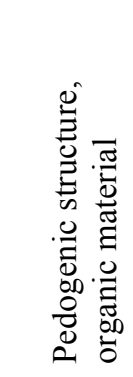 \\
\hline
\end{tabular}




\begin{tabular}{|c|c|c|c|c|c|c|}
\hline 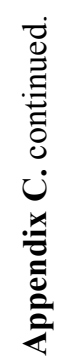 & 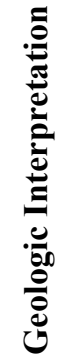 & 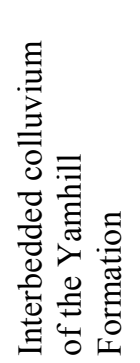 & 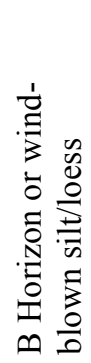 & 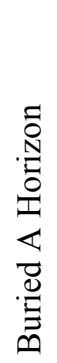 & 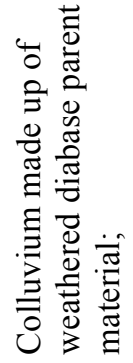 & 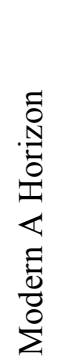 \\
\hline
\end{tabular}




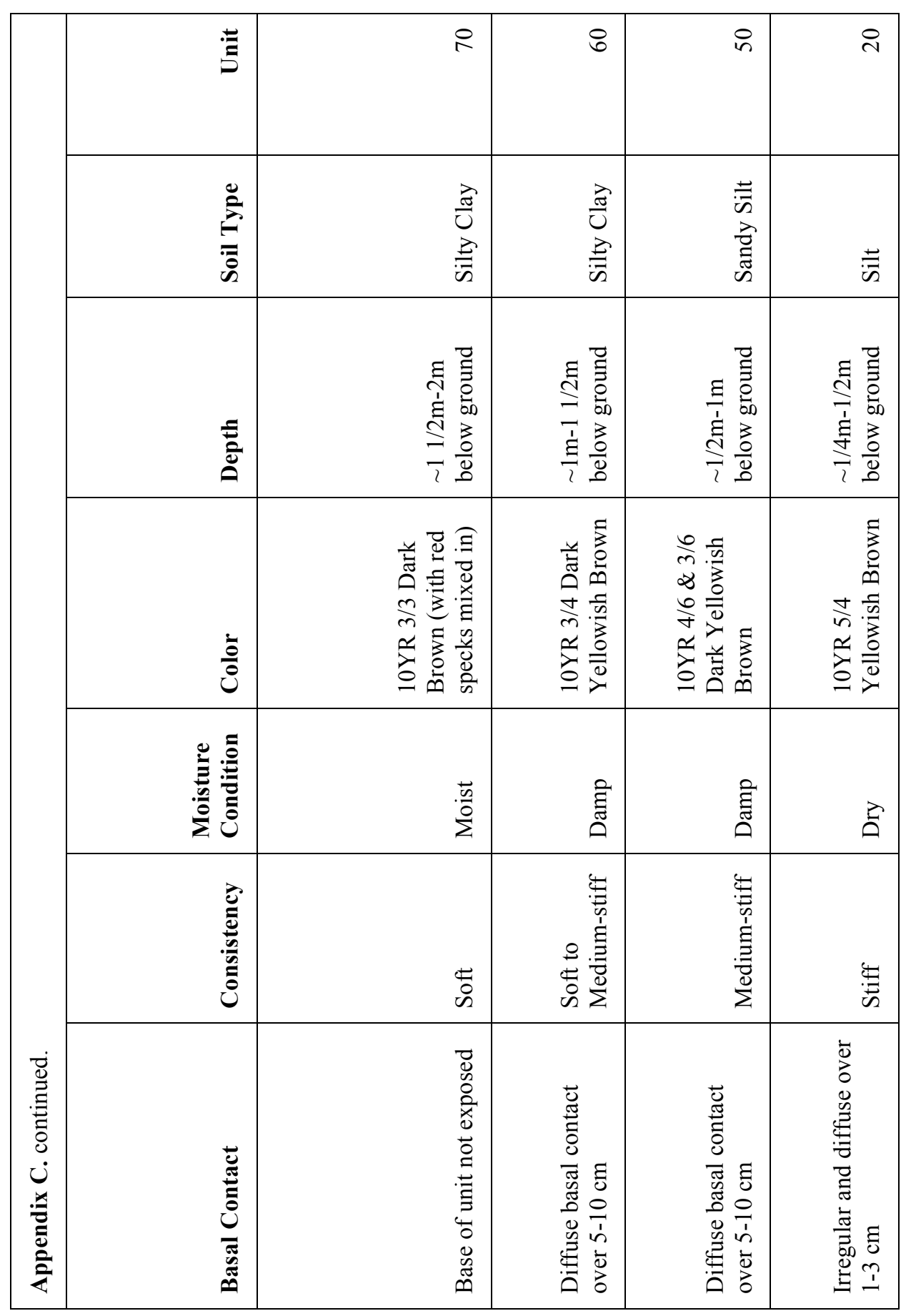




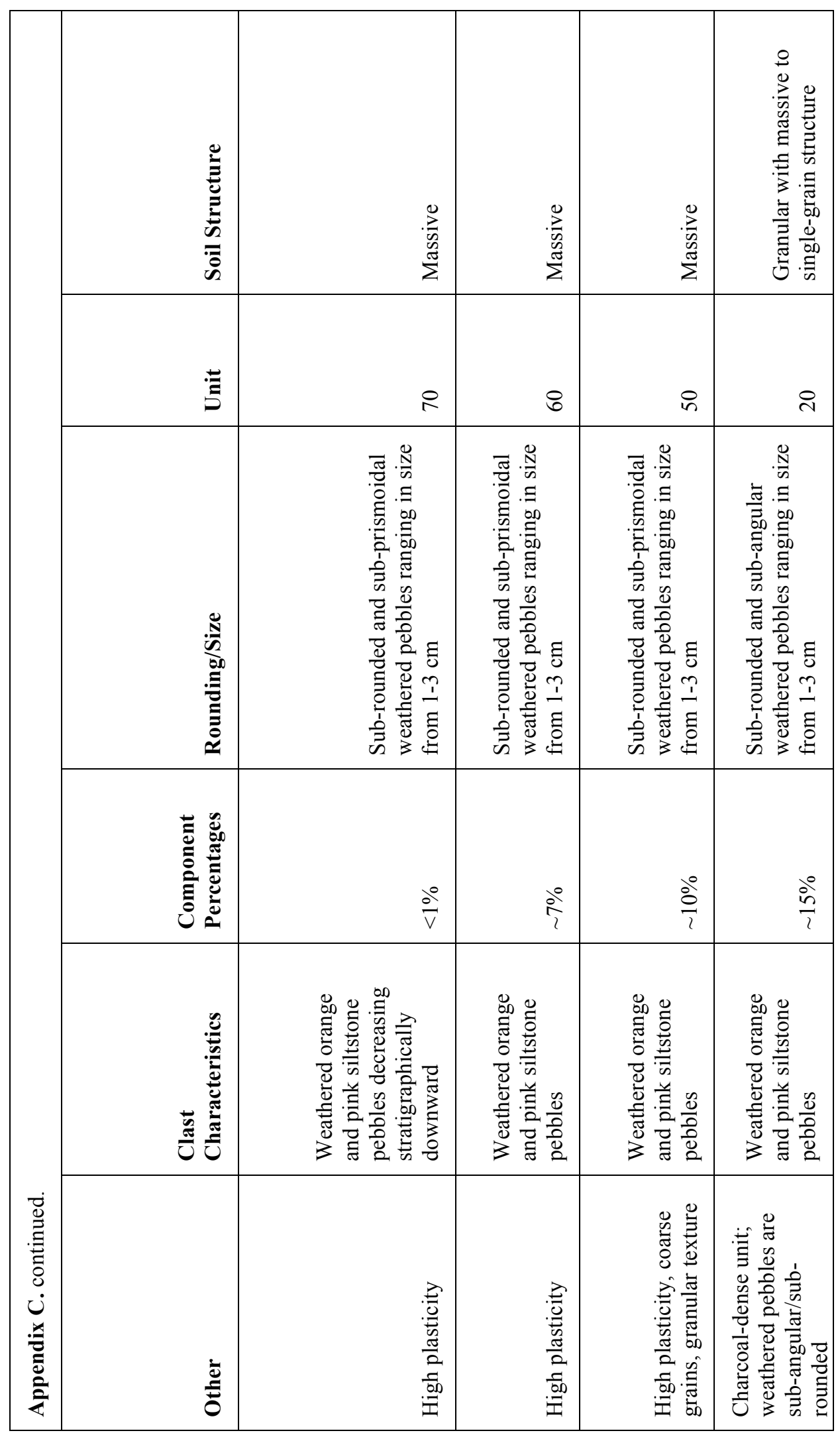




\begin{tabular}{|c|c|c|c|c|c|}
\hline 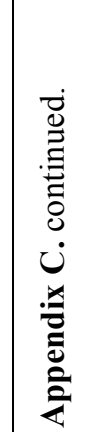 & 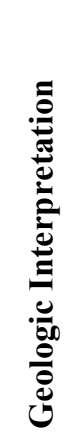 & 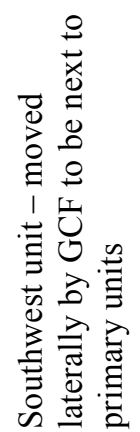 & 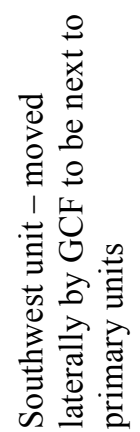 & 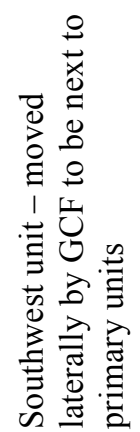 & 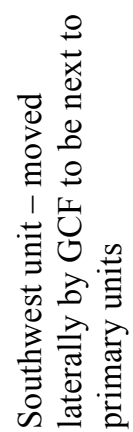 \\
\hline
\end{tabular}




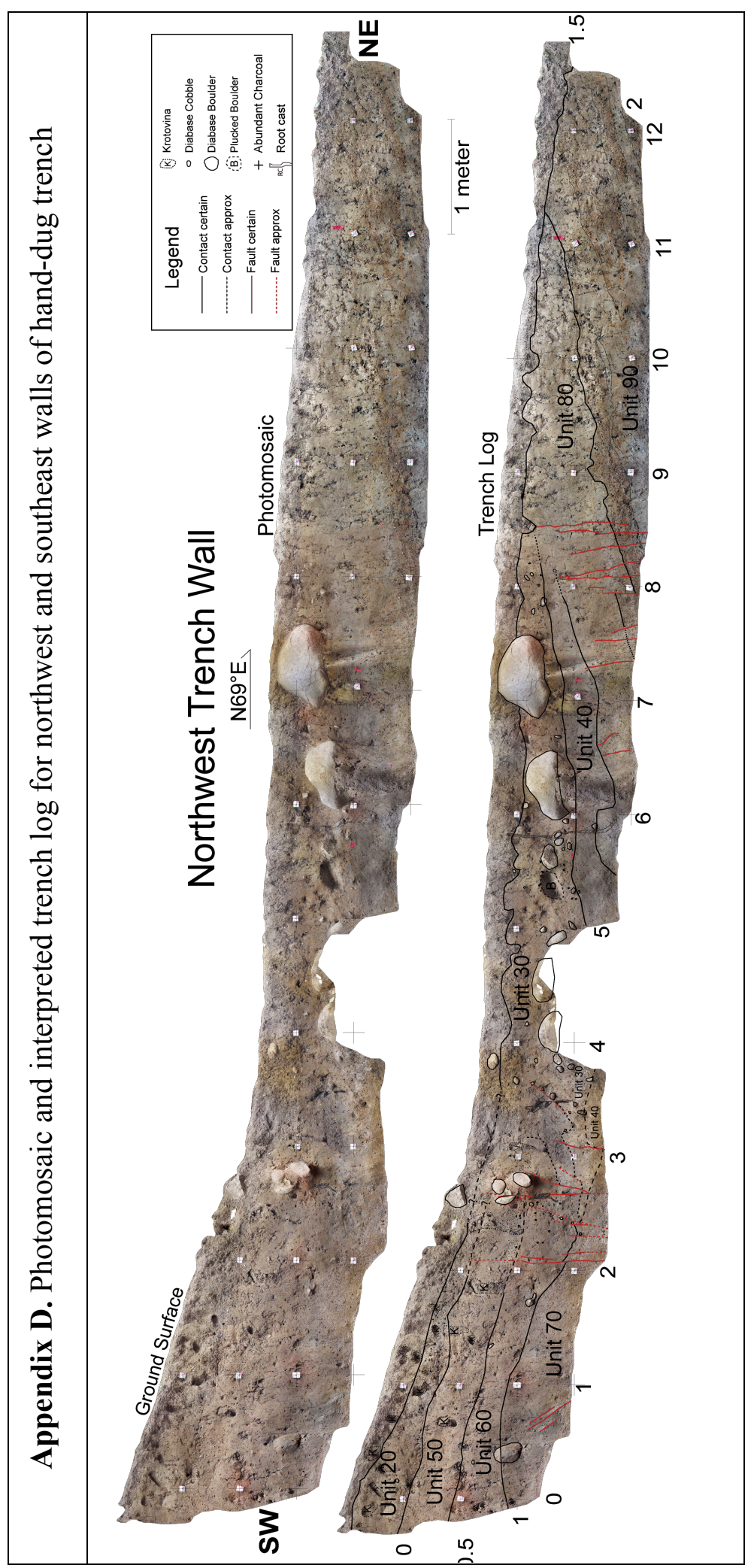




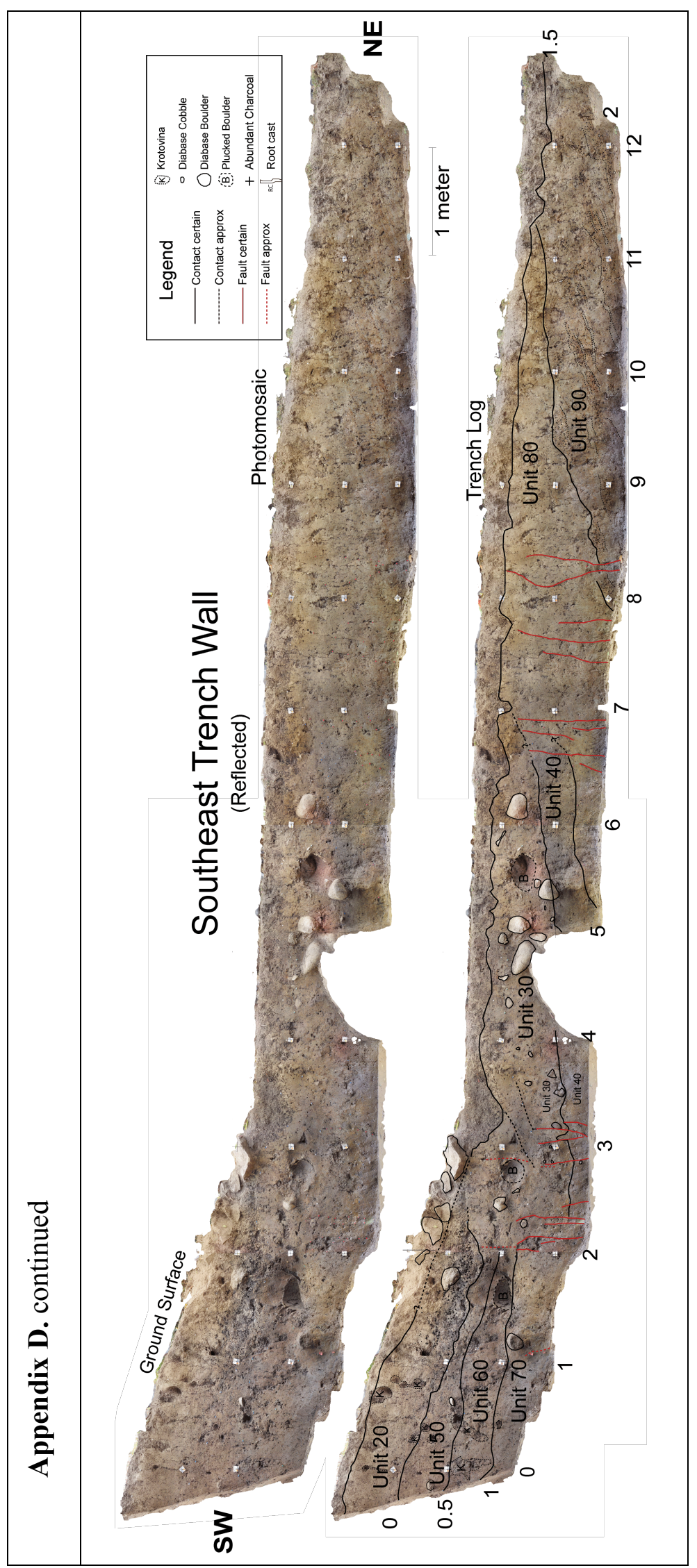


Appendix E. Photomosaic and interpreted trench log for north and south walls of Vtrench

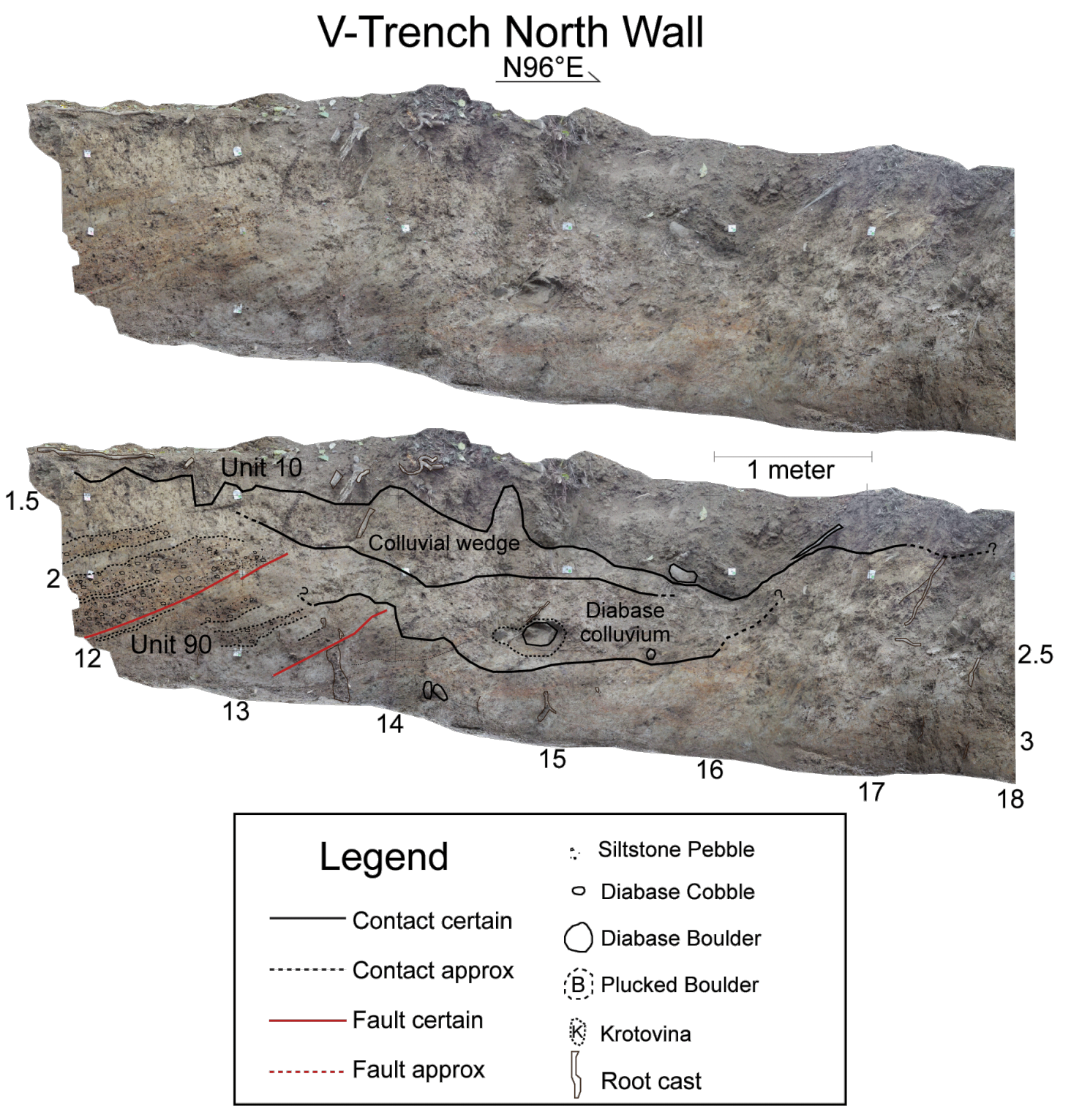


Appendix E. continued

\title{
V-Trench South Wall
}

\author{
$\angle \mathrm{N} 96^{\circ} \mathrm{E}$
}

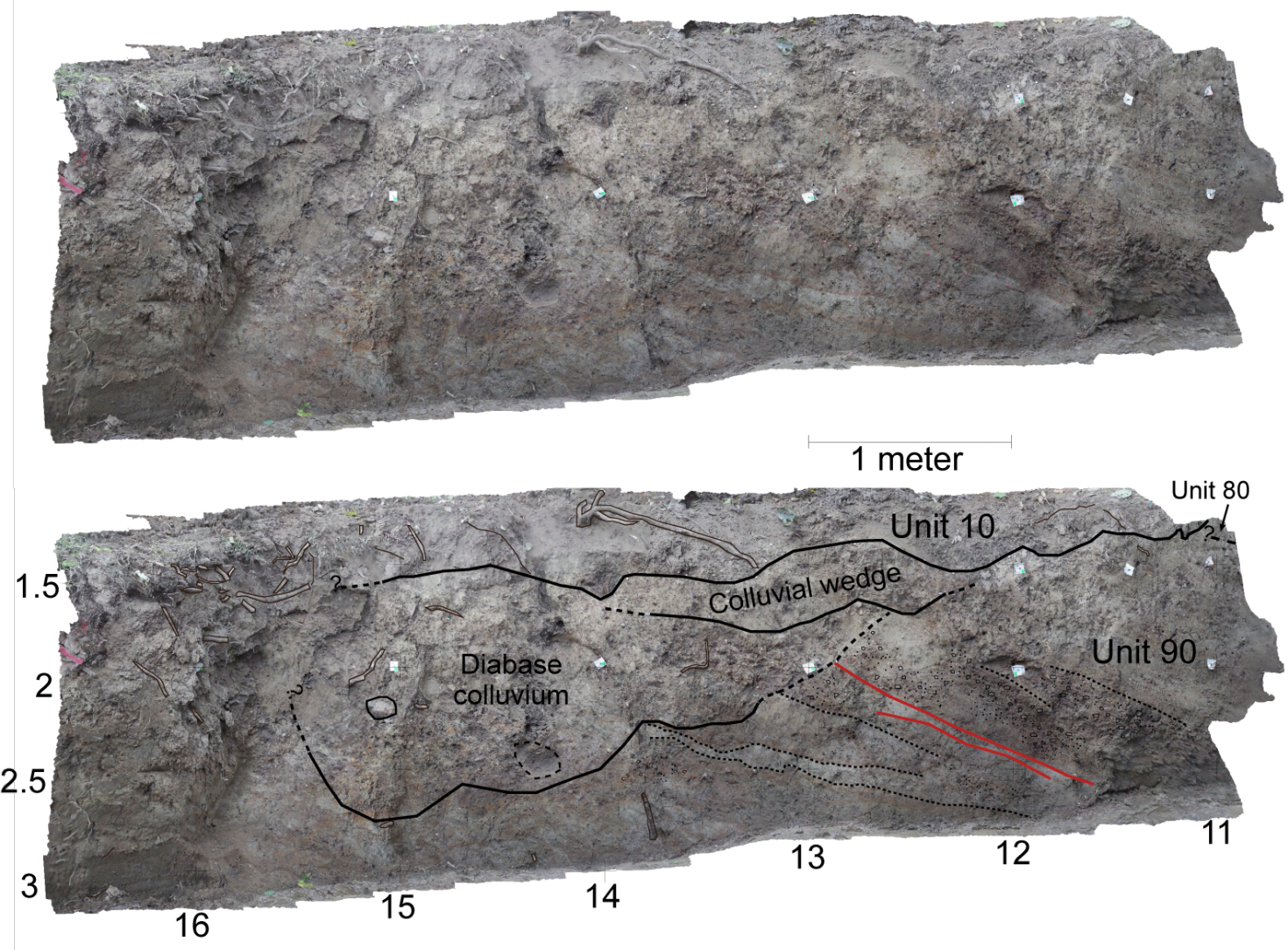

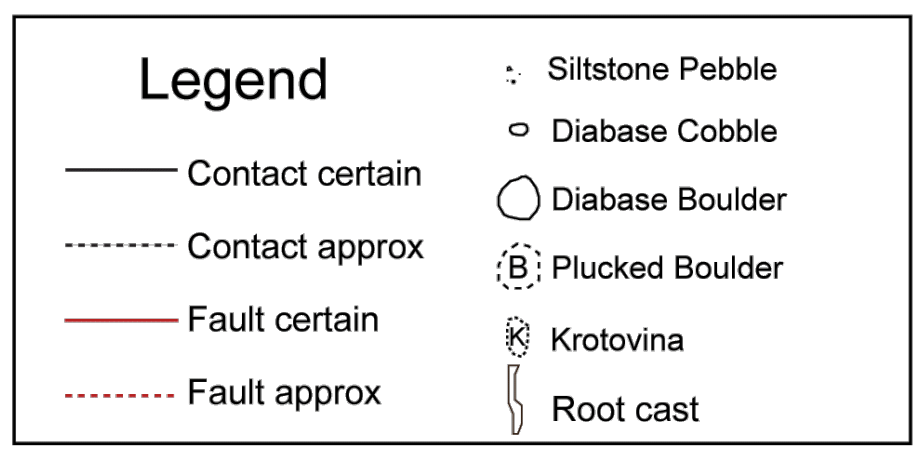


Appendix F. Summary of Earthquake Evidence

\begin{tabular}{|c|c|c|c|c|c|c|}
\hline Earthquake & Trench & $\begin{array}{l}\text { Location } \\
\text { in } \\
\text { Trench }\end{array}$ & $\begin{array}{l}\text { Earthquake } \\
\text { Evidence }\end{array}$ & $\begin{array}{c}\text { Earthquake } \\
\text { Horizon }\end{array}$ & $\begin{array}{c}\text { Earthquake } \\
\text { Qualifier }\end{array}$ & Rank \\
\hline E1 & Primary & $\begin{array}{l}\text { NW \& } \\
\text { SE m 2-4 }\end{array}$ & $\begin{array}{l}\text { Sub vertical fault } \\
\text { splays extend } \\
\text { upward into unit } \\
30 \text {. Units } 50,60, \\
\text { and } 70 \text { are } \\
\text { truncated on the } \\
\text { southwest by the } \\
\text { faults. Units } 30 \text { and } \\
40 \text { are truncated to } \\
\text { the northeast. }\end{array}$ & Unit 30 & Very Likely & 5 \\
\hline E1 & Primary & $\begin{array}{l}\text { NW \& } \\
\text { SE m 2-4 }\end{array}$ & $\begin{array}{l}\text { Upward } \\
\text { terminating fissure } \\
\text { within colluvial } \\
\text { unit } 30\end{array}$ & Unit 30 & Very Likely & 5 \\
\hline E1 & Primary & $\begin{array}{l}\text { NW m 3- } \\
4\end{array}$ & $\begin{array}{l}\text { Plucked cobbles of } \\
\text { unit } 30 \text { are upright } \\
\text { and aligned at } \\
\text { faults }\end{array}$ & Unit 30 & Very Likely & 5 \\
\hline E1 & $\begin{array}{l}\text { Hand- } \\
\text { dug }\end{array}$ & $\begin{array}{l}\text { (hand } \\
\text { dug) NW } \\
\text { m 2-3 }\end{array}$ & $\begin{array}{l}\text { Cobbles of unit } 30 \\
\text { are upright and } \\
\text { aligned at faults }\end{array}$ & Unit 30 & Very Likely & 5 \\
\hline E2 & Primary & $\begin{array}{l}\text { NW m 4- } \\
8 ; \text { SE m } \\
4-7\end{array}$ & $\begin{array}{l}\text { Upward fault } \\
\text { terminations within } \\
\text { unit } 40\end{array}$ & Unit 40 & Very Likely & 5 \\
\hline E2 & Primary & $\begin{array}{l}\text { NW m 5- } \\
6 ; \text { SE m } \\
5-6\end{array}$ & $\begin{array}{l}\text { Offset in base of } \\
\text { unit }\end{array}$ & Unit 40 & Very Likely & 5 \\
\hline E2 & Primary & $\begin{array}{l}\text { NW m 7- } \\
8 ; \text { SE m } \\
6-7\end{array}$ & $\begin{array}{l}\text { Unit } 40 \text { is in } \\
\text { vertical contact } \\
\text { with unit } 80\end{array}$ & Unit 40 & Very Likely & 5 \\
\hline E2 & Primary & $\begin{array}{l}\text { NW m 2- } \\
8 ; \text { SE m } \\
2-7\end{array}$ & $\begin{array}{l}\text { Buried soil } \\
\text { backtilted dipping } \\
\text { into the hillslope } \\
\text { and vertically offset } \\
\sim 0.5 \mathrm{~m}\end{array}$ & Unit 40 & Likely & 4 \\
\hline E2 & Primary & $\begin{array}{l}\text { NW m 2- } \\
8 ; \text { SE m } \\
2-7\end{array}$ & $\begin{array}{l}\text { Soil overlain by } \\
\text { colluvium with flat- } \\
\text { lying boulders }\end{array}$ & Unit 40 & Likely & 4 \\
\hline E2 & Primary & $\begin{array}{l}\text { NW m 3- } \\
8 ; \text { SE m } \\
3-7\end{array}$ & $\begin{array}{l}\text { Growth strata } \\
\text { observed from unit } \\
30 \text { thickening to the } \\
\text { SW }\end{array}$ & Unit 40 & Likely & 4 \\
\hline E3 & Primary & $\begin{array}{l}\text { SE m 2- } \\
7 ; \mathrm{NW} \mathrm{m} \\
2-8\end{array}$ & $\begin{array}{l}\text { Gradual thickening } \\
\text { in unit } 40 \text { to the } \\
\text { southwest }\end{array}$ & Unit 40 & Probable & 3 \\
\hline E3 & Primary & $\begin{array}{l}\text { SE m 2- } \\
7 ; \mathrm{NW} \mathrm{m} \\
2-8\end{array}$ & $\begin{array}{l}\text { Greater } \\
\text { sedimentation rate } \\
\text { in unit } 40{ }^{14} \mathrm{C} \\
\text { samples compared } \\
\text { to all samples } \\
\end{array}$ & Unit 40 & Probable & 3 \\
\hline
\end{tabular}




\begin{tabular}{|l|l|l|l|l|l|l|}
\hline & & $\begin{array}{l}\text { Gradational color } \\
\text { change in unit 40 } \\
\text { with apparent } \\
\text { contact (over } \sim 1-2 \\
\text { cm). Unit 40 is } \\
\text { E3 }\end{array}$ & $\begin{array}{l}\text { lighter above } \\
\text { SE m 2-5 } \\
\text { (vertical meter } \sim 1.8 .\end{array}$ & Unit 40 & Likely & \\
m 1.8) & Primary & & & \\
\end{tabular}

\begin{tabular}{|c|c|c|c|c|c|c|}
\hline \multicolumn{7}{|c|}{ Weak Evidence of Additional Earthquakes } \\
\hline Earthquake & Trench & $\begin{array}{c}\text { Location } \\
\text { in } \\
\text { Trench }\end{array}$ & $\begin{array}{c}\text { Earthquake } \\
\text { Evidence }\end{array}$ & $\begin{array}{c}\text { Earthquake } \\
\text { Horizon }\end{array}$ & $\begin{array}{c}\text { Earthquake } \\
\text { Qualifier }\end{array}$ & Rank \\
\hline E0 & $\begin{array}{l}\text { Hand- } \\
\text { dug }\end{array}$ & $\begin{array}{l}\text { NW m 2- } \\
3 ; \text { SE m } \\
2-3\end{array}$ & $\begin{array}{l}\text { Large, angular } \\
\text { boulders and cobbles } \\
\text { in place at hillslope } \\
\text { inflection point }\end{array}$ & Unit 10 & Probable & 3 \\
\hline E0 & Primary & SE $m$ 2-3 & $\begin{array}{l}\text { Large, angular } \\
\text { boulders and cobbles } \\
\text { in place at hillslope } \\
\text { inflection point }\end{array}$ & Unit 10 & Probable & 3 \\
\hline E0 & Primary & $\begin{array}{l}\text { NW m 3- } \\
4 ; \text { SE m } \\
3-4\end{array}$ & $\begin{array}{l}\text { Depression / fissure } \\
\text { within unit } 10\end{array}$ & Unit 10 & Probable & 3 \\
\hline $\mathrm{EE}$ & Primary & $\begin{array}{l}\text { NW m 7- } \\
12 ; \mathrm{SE} \mathrm{m} \\
7-11\end{array}$ & $\begin{array}{l}\text { Tilt of interbedded } \\
\text { unit } 90 \text { to the SW } \\
\text { after } \\
\text { retrodeformation }\end{array}$ & Unit 90 & Probable & 3 \\
\hline $\mathrm{EE}$ & $\begin{array}{l}\mathrm{V}- \\
\text { trench }\end{array}$ & $\begin{array}{l}\mathrm{N} \mathrm{m} \mathrm{12-} \\
14 ; \mathrm{S} \mathrm{m} \\
11-13\end{array}$ & $\begin{array}{l}\text { Reverse fault } \\
\text { stratigraphically } \\
\text { offsets unit } 90\end{array}$ & Unit 90 & Probable & 3 \\
\hline $\mathrm{EE}$ & $\begin{array}{l}\mathrm{V}- \\
\text { trench }\end{array}$ & $\begin{array}{l}\mathrm{N} \mathrm{m} \mathrm{13-} \\
16 ; \mathrm{S} \mathrm{m} \\
12-16\end{array}$ & $\begin{array}{l}\text { Diabase colluvium } \\
\text { stratigraphically } \\
\text { below reverse fault }\end{array}$ & Unit 90 & Probable & 3 \\
\hline
\end{tabular}




\begin{tabular}{|ccc|}
\hline Earthquake & Sum of Rank & Average Rank \\
E0 & 9 & 3 \\
E1 & 20 & 5 \\
E2 & 27 & 4.5 \\
E3 & 10 & 3.3 \\
EE & 9 & 3 \\
\hline
\end{tabular}

\section{Histogram of Event indicators compiled from above}

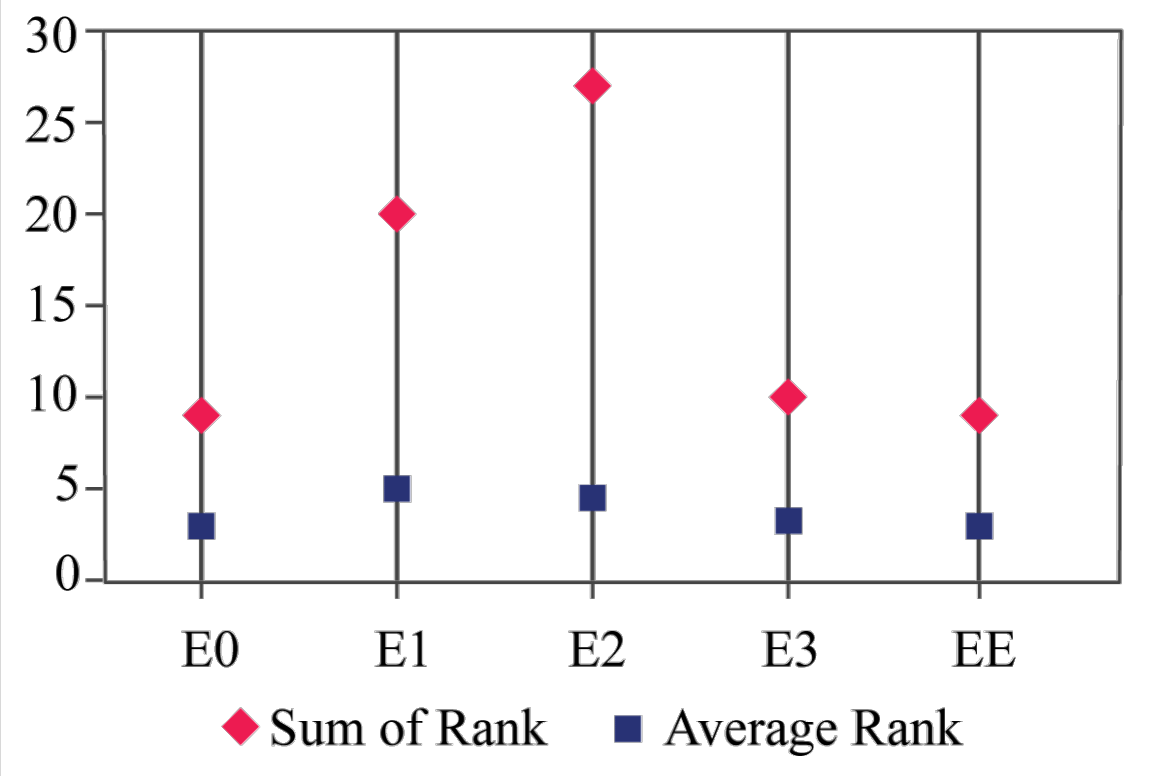


Appendix G. OxCal Model without earthquakes for samples not included in Figure 8 and Table of ${ }^{14} \mathrm{C}$ data with $2 \sigma$ uncertainty.

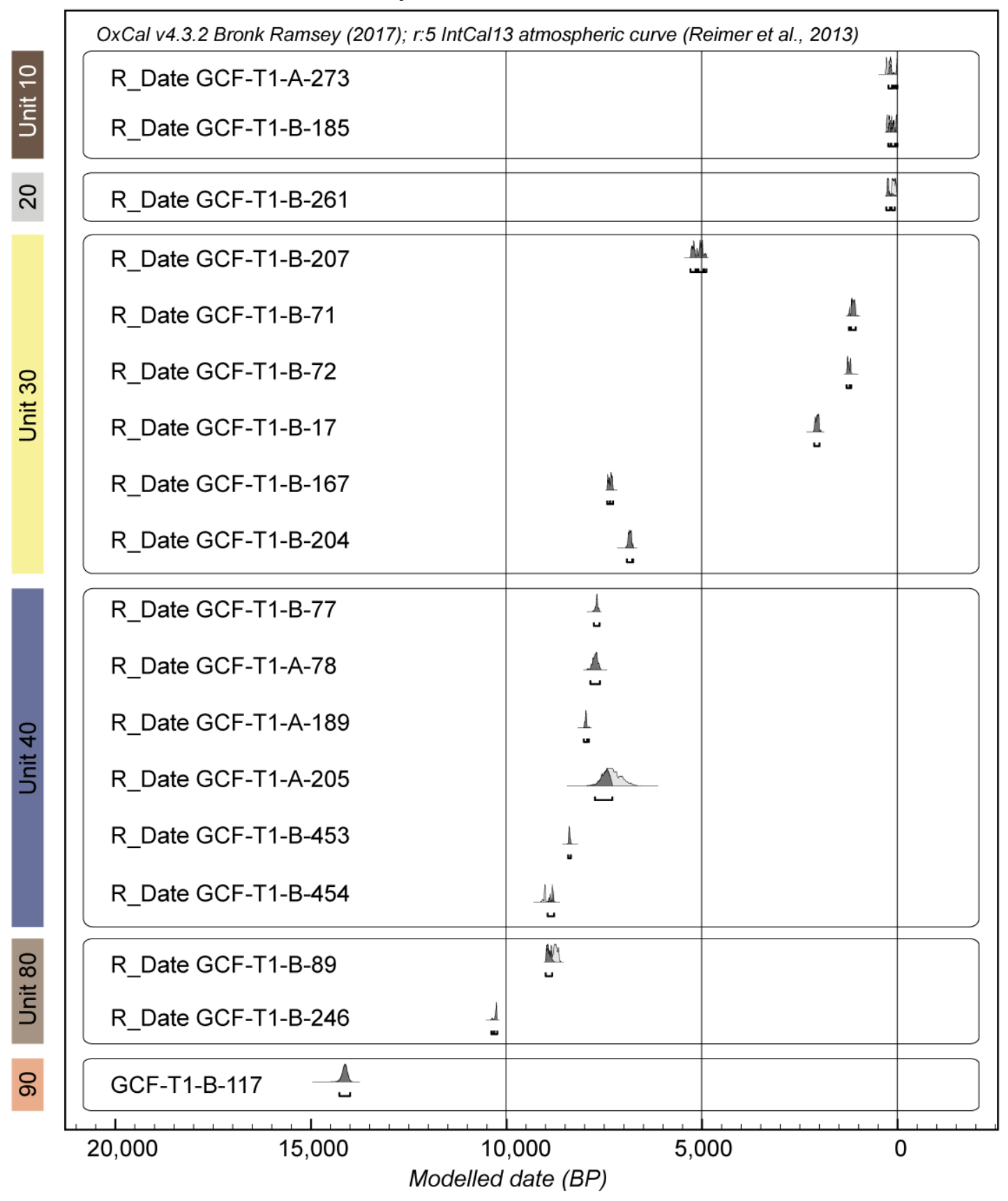




\begin{tabular}{|c|c|c|c|c|c|c|c|c|}
\hline \multirow[t]{2}{*}{ Name } & \multicolumn{3}{|c|}{ Unmodelled (BP) } & \multicolumn{5}{|c|}{ Modelled (BP) } \\
\hline & from & to & $\%$ & from & to & $\%$ & A & $\mathrm{C}$ \\
\hline R_Date GCF-T1-B-273 & 302 & $\ldots$ & 95.4 & 223 & -2 & 95.4 & 100.5 & 98.2 \\
\hline $\begin{array}{l}\text { R_Date GCF-T1-B-185 } \\
\text { Phase Unit10 }\end{array}$ & 282 & 5 & 95.4 & 230 & -2 & 95.4 & 97.7 & 99.4 \\
\hline $\begin{array}{l}\text { R_Date GCF-T1-B-261 } \\
\text { Phase Unit20 }\end{array}$ & 269 & 13 & 95.4 & 280 & 64 & 95.4 & 96.5 & 99.4 \\
\hline R_Date GCF-T1-B-207 & 5284 & 4880 & 95.5 & 5284 & 4881 & 95.3 & 99.5 & 98.9 \\
\hline R_Date GCF-T1-B-71 & 1234 & 1061 & 95.4 & 1235 & 1061 & 95.4 & 99.5 & 98.8 \\
\hline R_Date GCF-T1-B-72 & 1293 & 1181 & 95.4 & 1294 & 1181 & 95.4 & 99.2 & 99 \\
\hline R_Date GCF-T1-B-17 & 2125 & 1990 & 95.4 & 2125 & 1990 & 95.4 & 100.1 & 98.5 \\
\hline R_Date GCF-T1-B-167 & 7418 & 7271 & 95.4 & 7415 & 7269 & 95.4 & 100 & 99.1 \\
\hline $\begin{array}{l}\text { R_Date GCF-T1-B-204 } \\
\text { Phase Unit30 }\end{array}$ & 6910 & 6750 & 95.4 & 6911 & 6751 & 95.4 & 99.6 & 99.1 \\
\hline R_Date GCF-T1-B-77 & 7756 & 7615 & 95.4 & 7755 & 7615 & 95.4 & 99 & 99.1 \\
\hline R_Date GCF-T1-B-78 & 7844 & 7597 & 95.4 & 7844 & 7601 & 95.4 & 100 & 98.6 \\
\hline R_Date GCF-T1-A-189 & 8010 & 7883 & 95.4 & 8010 & 7883 & 95.4 & 99.8 & 98.9 \\
\hline R_Date GCF-T1-A-205 & 7691 & 6794 & 95.4 & 7732 & 7284 & 95.4 & 104.5 & 96.5 \\
\hline R_Date GCF-T1-B-453 & 8414 & 8344 & 95.4 & 8414 & 8345 & 95.4 & 99.5 & 99 \\
\hline $\begin{array}{l}\text { R_Date GCF-T1-B-454 } \\
\text { Phase Unit } 40\end{array}$ & 9123 & 8785 & 95.4 & 8940 & 8771 & 95.4 & 11.8 & 98.3 \\
\hline R_Date GCF-T1-B-89 & 8979 & 8642 & 95 & 8989 & 8823 & 95.4 & 89.5 & 99.6 \\
\hline $\begin{array}{l}\text { R_Date GCF-T1-B-246 } \\
\text { Phase Unit80 }\end{array}$ & 10378 & 10227 & 95.4 & 10376 & 10227 & 95.4 & 100 & 98.7 \\
\hline $\begin{array}{l}\text { R_Date GCF-T1-B-117 } \\
\text { Phase Unit90 }\end{array}$ & 14276 & 13991 & 95.4 & 14262 & 13989 & 95.4 & 100.7 & 96.8 \\
\hline $\begin{array}{l}\text { Boundary base } \\
\text { Sequence GCF_ClearC }\end{array}$ & & & & 14954 & 14145 & 95.4 & & 98.6 \\
\hline
\end{tabular}


Appendix H. Alternate OxCal Model with E2 between units 50 and 60, and Table of ${ }^{14} \mathrm{C}$ data with $2 \sigma$ uncertainty.

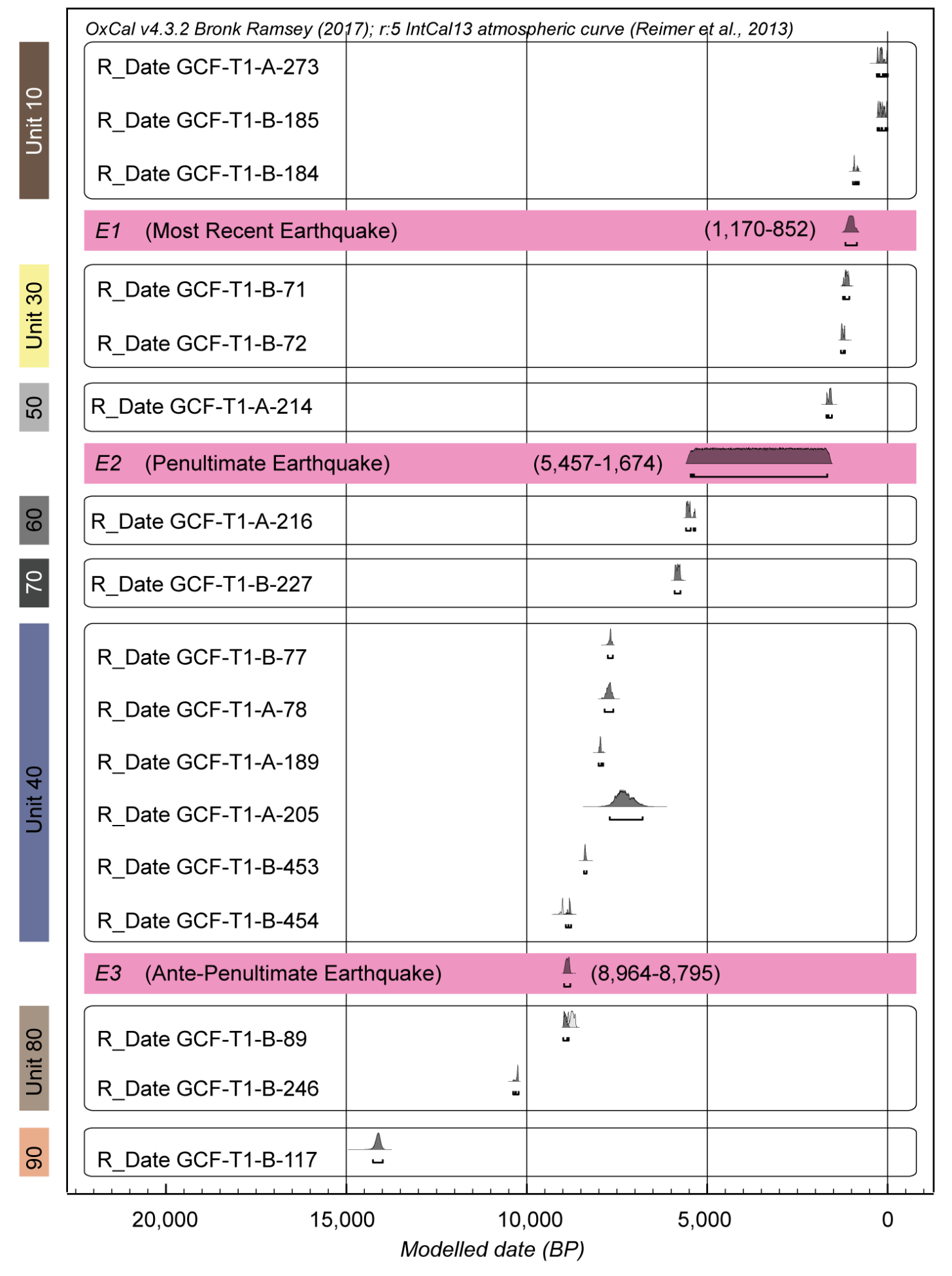




\begin{tabular}{|c|c|c|c|c|c|c|c|c|}
\hline \multirow[t]{2}{*}{ Name } & \multicolumn{3}{|c|}{ Unmodelled (BP) } & \multicolumn{5}{|c|}{ Modelled (BP) } \\
\hline & from & to & $\%$ & from & to & $\%$ & A & $\mathrm{C}$ \\
\hline R_Date GCF-T1-A-273 & 301 & $\ldots$ & 95.4 & 301 & -2 & 95.5 & 99.2 & 99.2 \\
\hline R_Date GCF-T1-B-185 & 282 & 5 & 95.4 & 282 & 3 & 95.3 & 98.5 & 99.6 \\
\hline R_Date GCF-T1-B-184 & 963 & 800 & 95.3 & 960 & 799 & 95.4 & 92.7 & 99.4 \\
\hline \multicolumn{9}{|l|}{ Phase Unit10 } \\
\hline E1 & & & & 1170 & 852 & 95.4 & & 99.7 \\
\hline R_Date GCF-T1-B-71 & 1234 & 1061 & 95.4 & 1236 & 1063 & 95.4 & 97.6 & 99.5 \\
\hline R_Date GCF-T1-B-72 & 1293 & 1181 & 95.4 & 1293 & 1181 & 95.4 & 99.2 & 99.4 \\
\hline \multicolumn{9}{|l|}{ Phase Unit30 } \\
\hline R_Date GCF-T1-A-214 & 1697 & 1544 & 95.4 & 1697 & 1544 & 95.4 & 99.8 & 99.4 \\
\hline \multicolumn{9}{|l|}{ Phase Unit50 } \\
\hline $\mathrm{E} 2$ & & & & 5457 & 1674 & 95.5 & & 96.7 \\
\hline R_Date GCF-T1-A-216 & 5586 & 5331 & 95.4 & 5586 & 5331 & 95.4 & 99.7 & 99.5 \\
\hline \multicolumn{9}{|l|}{ Phase Unit60 } \\
\hline R_Date GCF-T1-B-227 & 5905 & 5741 & 95.4 & 5904 & 5741 & 95.4 & 99.7 & 99.5 \\
\hline \multicolumn{9}{|l|}{ Phase Unit70 } \\
\hline R_Date GCF-T1-B-77 & 7756 & 7615 & 95.4 & 7755 & 7615 & 95.4 & 99.7 & 99.6 \\
\hline R_Date GCF-T1-B-78 & 7844 & 7597 & 95.4 & 7844 & 7601 & 95.4 & 100 & 99.1 \\
\hline R_Date GCF-T1-A-189 & 8010 & 7883 & 95.4 & 8010 & 7883 & 95.4 & 99.6 & 99.2 \\
\hline R_Date GCF-T1-A-205 & 7691 & 6794 & 95.4 & 7700 & 6792 & 95.4 & 99.8 & 97.1 \\
\hline R_Date GCF-T1-B-453 & 8414 & 8344 & 95.4 & 8414 & 8344 & 95.4 & 99.9 & 99.5 \\
\hline R_Date GCF-T1-B-454 & 9123 & 8785 & 95.4 & 8916 & 8770 & 95.4 & 12.1 & 99.5 \\
\hline \multicolumn{9}{|l|}{ Phase Unit 40} \\
\hline E3 & & & & 8964 & 8795 & 95.4 & & 99.8 \\
\hline R_Date GCF-T1-B-89 & 8979 & 8642 & 95.4 & 8990 & 8837 & 95.4 & 88.2 & 99.8 \\
\hline R_Date GCF-T1-B-246 & 10378 & 10227 & 95.4 & 10376 & 10227 & 95.4 & 99.6 & 99.5 \\
\hline \multicolumn{9}{|l|}{ Phase Unit 80} \\
\hline R_Date GCF-T1-B-117 & 14276 & 13991 & 95.4 & 14261 & 13990 & 95.4 & 101.1 & 99.1 \\
\hline \multicolumn{9}{|l|}{ Phase Unit90 } \\
\hline Boundary base & & & & 14954 & 14147 & 95.4 & & 99.3 \\
\hline Sequence GCF_ClearCk & 2018 & & & & & & & \\
\hline
\end{tabular}


Appendix I. Links for publically accessible data sources used in this study

\begin{tabular}{|l|l|l|}
\hline \multicolumn{1}{|c|}{ Data Type } & \multicolumn{1}{|c|}{ Source } & \multicolumn{1}{c|}{ URL } \\
\hline OxCal & $\begin{array}{l}\text { ORAU - OxCal } \\
\text { online }\end{array}$ & $\begin{array}{l}\text { https://c14.arch.ox.ac.uk/ } \\
\text { oxcal/OxCal.html }\end{array}$ \\
\hline Lidar & $\begin{array}{l}\text { DOGAMI lidar } \\
\text { viewer }\end{array}$ & $\begin{array}{l}\text { https:/gis.dogami.oregon.gov/ } \\
\text { maps/lidarviewer/ }\end{array}$ \\
\hline
\end{tabular}

